Texto sistematizado elaborado de forma crítica

\author{
CESAR DE ALMEIDA NETO
}

\title{
Estudos observacionais e de intervenção dentro de um hemocentro: implicações para as políticas e práticas na hemoterapia
}

Texto sistematizado elaborado de forma crítica, apresentado ao Instituto de Medicina Tropical de São Paulo para concorrer ao Título de Livre-Docente da Universidade de São Paulo junto ao Programa da Disciplina de Hematologia Tropical 
Ficha catalográfica

Preparada pela Biblioteca do Instituto de Medicina Tropical de São Paulo da

Universidade de São Paulo

(C) Reprodução autorizada pelo autor

Almeida Neto, Cesar de

Estudos observacionais e de intervenção dentro de um hemocentro : implicações para as políticas e práticas na hemoterapia / Cesar de Almeida Neto. - São Paulo, 2016.

Texto sistematizado elaborado de forma crítica - Instituto de Medicina Tropical de São Paulo da Universidade de São Paulo, para concurso de livre-docência

Área de concentração: Doenças Tropicais e Saúde Internacional - Disciplina de Hematologia Tropical

Descritores: 1. DOADORES DE SANGUE. 2. HEPATITE VIRAL HUMANA. 3. SÍFILIS. 4. HIV. 5. SÍNDROME DE IMUNODEFICIÊNCIA ADQUIRIDA. 6. SEGURANÇA TRANSFUSIONAL. 7. MEDICINA TRANSFUSIONAL. 
Este Texto sistematizado elaborado de forma crítica está de acordo com as recomendações do Grupo de Vancouver (Uniform Requirements for Manuscripts Submitted to Biomedical Journals, International Committee of Medical Journal Editors http://www.icmje.org), com destaque, em itálico, para os títulos de livros, teses, dissertações, monografias e periódicos. 


\section{DEDICATÓRIA}

Dedico este trabalho a minha amada esposa Maristela Gomes de Almeida. Uma estrela que guia minha vida e brilha para iluminar meus caminhos. Dedico a você os seguintes versos de uma canção que gostamos muito:

"You're a falling star, you're the get away car
You're the line in the sand when I go too far
You're the swimming pool on an August day
And you're the perfect thing to say" (Michael Buble e Alan Chang)

Dedico as minhas amadas filhas Isadora Maria Gomes de Almeida e Clarisssa Maria Gomes de Almeida. Vocês são nossa maior alegria e nosso estímulo constante para sermos melhores a cada dia.

Dedico aos meus queridos pais Regina Celi de Almeida e José Cesar de Almeida (in memorian). Agradeço sempre a Deus pelos pais carinhosos e maravilhosos que tive e tenho. Vocês são meus ídolos. Só tenho bons pensamentos e sentimentos por vocês.

Dedico ao meu irmão José Marcelo de Almeida que sempre dividiu comigo os bons e maus momentos da vida.

Dedico a minha querida prima Maria Thereza Pinheiro de Almeida que sempre foi o meu Norte. Amo muito você prima. 


\section{AGRADECIMENTOS}

A professora doutora. Ester Cerdeira Sabino pela sua liderança, amizade e capacidade de sempre fazer "do limão uma limonada".

Ao doutor Alfredo Mendrone-Junior pela amizade, confiança e profissionalismo.

Ao professor doutor Vanderson Rocha que inicia sua trajetória como professor titular do Departamento de Hematologia e traz boas ideias, muita vontade e uma maneira diferente de educar toda uma geração de médicos, residentes e alunos.

Aos meus colegas médicos da Fundação Pró-Sangue, do Hospital das Clínicas da FMUSP e do Hospital Nove de Julho, pelo carinho, paciência e apoio que recebo no dia a dia do meu trabalho.

Aos colaboradores da Fundação Pró-Sangue, em especial do Departamento de Aféreses, pela inestimável ajuda, dedicação e pelo trabalho de excelência que realizam.

Aos colaboradores do Serviço de Hemoterapia do Hospital Nove de Julho pelo carinho e fidelidade que dispensam a mim a cada dia que lá estou.

A senhora Villene Matias e ao senhor Carlos José Quinteiro, pela inestimável ajuda na elaboração do Memorial Descritivo e ficha catalográfica deste trabalho.

Aos pesquisadores e pesquisados que tornaram este trabalho possível.

A minha brilhante filha Isadora Maria Gomes de Almeida pelas correções ortográficas e de sintaxe.

A todos meus alunos e mestres, em especial doutora Edi Cabral, aprendi e continuo aprendendo muito com cada um de vocês. 
O amor é a maior das virtudes.

O amor jamais acabará.

As profecias desaparecerão.

O dom das línguas cessará, o dom da ciência findará.

A nossa ciência é parcial, a nossa profecia é imperfeita.

Quando chegar o que é perfeito, o imperfeito desaparecerá.

Por ora subsistem a fé, a esperança e o amor - as três.

Porém, a maior delas é o amor.

Primeira Epístola de São Paulo aos Coríntios 


\section{SUMÁRIO}

Lista de abreviaturas e siglas

Lista de anexos

Resumo

Summary

1. INTRODUÇÃO 1

2. RECRUTAMENTO, TRIAGEM E COLETA 5

2a. Temporalidade e intervalos das doações de sangue 5

2b. Triagem hematológica de candidatos à doação de sangue 10

2c. Triagem clínica de doadores de sangue e voto de autoexclusão 17

2d. Orientações educacionais na doação, motivação de

$\begin{array}{ll}\text { doadores e capital social } & 22\end{array}$

3. DOENÇAS TRANSMISSÍVEIS POR TRANSFUSÃO 28

3a. Vírus da imunodeficiência humana 28

3b. Hepatites virais $\quad 45$

3c. Sífilis 58

3d. Doença de Chagas $\quad 65$

4. USO RACIONAL DOS HEMOCOMPONENTES E OUTRAS PESQUISAS

$\begin{array}{ll}\text { COM DOADORES E RECEPTORES DE SANGUE } & 72\end{array}$

$\begin{array}{ll}\text { 4a. Uso racional do sangue e hemocomponentes } & 72\end{array}$

4b. Eficácia da plataforma OpenArray na identificação de alterações

genéticas relacionadas a trombose e hemocromatose hereditária em

doadores de sangue

4c. Prevenção da Lesão Pulmonar Aguda Relacionada à

$\begin{array}{ll}\text { Transfusao (TRALI) } & 78\end{array}$

4d. Recrutamento de doadores com sorologias alteradas $\quad 80$

$\begin{array}{lrl}\text { CONCLUSÕES } & 84\end{array}$

$\begin{array}{ll}\text { REFERÊNCIAS BIBLIOGRÁFICA } & 88\end{array}$

ANEXOS 


\section{Lista de abreviaturas e siglas}

ACASI audio computer-assisted structured interviews ou autoentrevista estruturada e computadorizada com áudio e vídeo

ALT alaninotransferase

Agp24 Antígeno p24

anti-HBc Anticorpo anticore do vírus da hepatite B

AOR Razão de chance ajustada

CGIAMT Grupo Cooperativo Iberoamericano de Medicina Transfusional

CO/S cut-off/sample ou limite de corte sobre densidade óptica

CTAs Centros de Testagem e Aconselhamento

DNA ácido desoxirribonucleico

ECG eletrocardiograma

ECO ecocardiograma

EIA Ensaio imunoenzimático

EUA Estados Unidos da América

FRET Fluorescence resonance energy transfer (Transferência ressonante de energia por fluorescência)

FTA-ABS Fluorescent Treponemal Antibody Absorption Test

g/dl gramas/decilitro

HBsAg Antígeno de superfície do vírus da hepatite B

HBV Vírus da Hepatite B

HCV Vírus da Hepatite C

HIV Vírus da imunodeficiência humana

HIV RNA Ácido ribonucleico do vírus da imunodeficiência humana

HSH Homem que mantem/manteve relação sexual com outro homem

kg quilograma

LDQOL-1.0 Liver Disease Quality of Life

$\mathrm{mmHg} \quad$ milimetro de mercúrio 
NAT Tecnologia de Ácidos Nucleico

$\mathrm{ng} / \mathrm{ml} \quad$ nanogramas/mililitros

OPAS Organização Panamericana da Saúde

OR Razão de chance

PaO2/FiO2 Pressão arterial de oxigênio/fração de injeção do oxigênio

PCR reação em cadeia da polimerase

QVRS Qualidade de Vida Relacionada à Saúde

REDS Retrovirus Epidemiology Donors Study

RNA ácido ribonucleico

S/CO sample to cut-off ou densidade óptica sobre o limite de corte

SF-36 Medical Outcome Study-36 Item Short Form Health Survey

SMS Short Message Service

STS Testes Sorológicos para Sífilis

SUS Sistema Único de Saúde

TGI trato gastrointestinal

TMRCA Tempo para o Ancestral Comum Mais Recente

T. cruzi Tripanossoma cruzi

T. pallidum Treponema pallidum

TRALI Lesão Pulmonar Aguda Relacionada à Transfusao

VDRL Venereal Disease Research Laboratory

VPP Valor preditivo positivo

$>\quad$ maior

$<\quad$ menor

$=\quad$ igual 


\section{Anexos}

ANEXO 1. Temporal distribution of blood donations in three Brazilian blood centers and its repercussion on the blood supply. Oliveira CD, de Almeida-Neto C, Liu EJ, Sabino EC, Leão SC, Loureiro P, Wright D, Custer B, Gonçalez TT, Capuani L, Busch M, Proietti AB.Rev Bras Hematol Hemoter. 2013;35:246-51.

ANEXO 2. Interdonation intervals and patterns of return among blood donors in Brazil. de Almeida Neto C, Mendrone Jr A, Custer B, Liu J, Carneiro-Proietti AB, Leao SA, et al. Transfusion 2012;52:722-8.

ANEXO 3. Anemia screening in potential female blood donors: comparison of two different quantitative methods. Mendrone Jr A, Sabino EC, Sampaio L, Neto CA, Schreiber GB, de Alencar Fischer Chamone D, Dorlhiac-Llacer PE. Transfusion 2009;49:662-668.

ANEXO 4. Risk factors for deferral due to low hematocrit and iron depletion among prospective blood donors in a Brazilian center. Dauar ET, Patavino GM, Mendrone Júnior A, Gualandro SF, Sabino EC, de Almeida-Neto C. Rev Bras Hematol Hemoter. $2015 ; 37(5): 306-15$ 
ANEXO 5. Impact of allogeneic 2-RBC apheresis on iron stores of Brazilian blood donors. Transfusion and Apheresis. Mendrone Jr A, Arrais CA, de Almeida Neto C, Gualandro SFM, Dorlhiac-Llacer PE, Chamone DAF, Sabino EC. Science 2009;41:13-17.

ANEXO 6. Number of recent sexual partners among blood donors in Brazil: associations with donor demographics, donation characteristics and infectious disease markers. Patavino GM, de Almeida-Neto C, Liu J, Wright DJ, Mendrone-Junior A, Ferreira MIL, Carneiro ABF, Custer B, Ferreira JE, Busch MP, Sabino EC. Transfusion 2012;52:151-9.

ANEXO 7. Demographic characteristics and prevalence of serologic markers among blood donors who use confidential unit exclusion (CUE) in São Paulo, Brazil: implications for modification of CUE polices in Brazil. De Almeida-Neto C, Liu J, Wright DJ, Mendrone-Junior A, Takecian PL, Sun Y, Ferreira JE, de Alencar Fischer Chamone D, Busch MP, Sabino EC. Transfusion 2012;52:151-159.

ANEXO 8. The impact of simple donor education on donor behavioral deferral and infectious disease rates in São Paulo, Brazil. Gonçalez TT, Sabino EC, Salles NA, de Almeida-Neto C, Mendrone-Jr A, Dorlhiac-Laccer PE, Liu J, Murphy EL, Schreiber GB. Transfusion 2010;50:909-917. 
ANEXO 9. Motivation and social capital among prospective blood donors in three large blood centers in Brazil. Gonçalez TT, Di Lorenzo Oliveira C, Carneiro-Proietti AB, Moreno EC, Miranda C, Larsen N, Wright D, Leão S, Loureiro P, de Almeida-Neto C, Lopes MI, Proietti FA, Custer B, Sabino E; for the NHLBI Retrovirus Epidemiology Donor Study-II (REDS-II), International Component. Transfusion. 2013;53:1291-301.

ANEXO 10. Relationship between social capital and test seeking among blood donors in Brazil. Vox Sang. Oliveira CD, Goncalez T, Wright D, Rocha PC, Miranda C, Capuani L, Carneiro-Proietti AB, Proietti FA, de Almeida-Neto C, Larsen NM, Sampaio D, Custer B; for the NHLBI Retrovirus Epidemiology Donor Study-II (REDS-II), International Component. 2013;104:100-109.

ANEXO 11. A single window-period donation detected by human immunodeficiency virus p24 antigen after 5 years of routine screening in a group of Brazilian blood banks. Wendel S, Fachini RM, Levi JE, Ghaname JN, Mendonça MC, de Almeida Neto C, Braga MC, Pietro AE. Vox Sanguinis 2002;83:309-312.

ANEXO 12. Performance of parallel screening of Brazilian blood donors with two human immunodeficiency virus immunoassays: implications for sequential immunoassay testing algorithms in other countries. Sabino EC, Salles NA, de Almeida- 
Neto C, Barreto AM, Basques F, Barros EA, Mendrone Jr A, Busch MP. Transfusion 2011;51:175-183.

ANEXO 13. Risk factors for human immunodeficiency virus infection among blood donors in Sao Paulo, Brazil, and their relevance to current donor deferral criteria. Almeida Neto C, McFarland W, Murphy EL, Chen S, Nogueira FAH, Mendrone Junior A, Chamone DAF, Sabino EC. Transfusion 2007;47:608-614.

ANEXO 14. Risk factors for human immunodeficiency virus infection among Brazilian blood donors: a multicentre case-control study using audio computer-assisted structured interviews. de Almeida-Neto C, Goncalez TT, Birch RJ, de Carvalho SM, Capuani L, Leão SC, Miranda C, Rocha PC, Carneiro-Proietti AB, Johnson BR, Wright DJ, Murphy EL, Custer B; NHLBI Retrovirus Epidemiology Donor Study-II (REDS-II) International Component, Brazil. Vox Sang. 2013;105:91-9.

ANEXO 15. Undisclosed human immunodeficiency virus risk factors identified through a computer-based questionnaire program among blood donors in Brazil. Blatyta PF, Custer B, Gonçalez TT, Birch R, Lopes ME, Lopes Ferreira MI, Carneiro Proietti AB, Sabino EC, Page K, de Almeida-Neto C; NHLBI Retrovirus Epidemiology Donor Study-II International Component. Transfusion. 2013;53:2734-43. 
ANEXO 16. Knowledge of HIV testing and attitudes towards blood donation at three blood centres in Brazil. Miranda C, Moreno E, Bruhn R, Larsen NM, Wright DJ, Oliveira CD, Carneiro-Proietti AB, Loureiro P, de Almeida-Neto C, Custer B, Sabino EC, Gonçalez TT; NHLBI Retrovirus Epidemiology Donor Study-II (REDS-II), International Component. Vox Sang. 2014;106:344-53.

ANEXO 17. Prevalence of serologic markers for hepatitis B and C viruses in Brazilian blood donors and incidence and residual risk of transfusion transmission of hepatitis C virus. de Almeida-Neto C, Sabino EC, Liu J, Blatyta PF, Mendrone-Junior A, Salles NA, Leão SC, Wright DJ, Basques FV, Ferreira JE, Busch MP, Murphy EL. Transfusion 2013;53:827-34.

ANEXO 18. Significance of isolated hepatitis B core antibody in blood donors from São Paulo. Almeida Neto C, Strauss E, Sabino EC, Sucupira MCA, Chamone DAF. Revista do Instituto de Medicina Tropical de São Paulo 2001;43:203-208.

ANEXO 19. Clinical significance of elevated alanine aminotransferase in blood donors: a follow-up study. Torezan Filho MA, Alves VAF, Neto CA, Fernandes HS, Strauss E. Liver International 2004;24:575-581. 
ANEXO 20. HCV genotypes, characterization of mutations conferring drug resistance to protease inhibitors, and risk factors among blood donors in São Paulo, Brazil. Nishiya AS, de Almeida-Neto C, Ferreira SC, Alencar CS, Di-Lorenzo-Oliveira C, Levi JE, Salles NA, Mendrone A Jr, Sabino EC.. PLoS One. 2014 Jan 21;9(1):e86413.

ANEXO 21. Phylogenetic analysis of the emergence of main hepatitis $C$ virus subtypes in São Paulo, Brazil. Nishiya AS, de Almeida-Neto C, Romano CM, Alencar CS, Ferreira SC, Di-Lorenzo-Oliveira C, Levi JE, Salles NA, Mendrone-Junior A, Sabino EC. Braz J Infect Dis. 2015;19(5):473-8.

ANEXO 22. Altered quality of life in the early stages of chronic hepatitis $\mathbf{C}$ is due to the virus itself. Strauss E, Porto-Ferreira FA, de Almeida-Neto C, Teixeira MC. Clin Res Hepatol Gastroenterol. 2014;38:40-5.

ANEXO 23. Health-related quality of life among blood donors with hepatitis B and hepatitis C: longitudinal study before and after diagnosis. Ferreira FA, de AlmeidaNeto C, Teixeira MC, Strauss E. Rev Bras Hematol Hemoter. 2015 Nov-Dec;37(6):381-7

ANEXO 24. Profile of blood donors with serologic tests reactive for the presence of syphilis in São Paulo, Brazil. de Almeida Neto C; Murphy EL; McFarland W, Junior AM, Chen S, Chamone DAF, Sabino EC. Transfusion 2009;49:330-336. 
ANEXO 25. Demographic, risk factors and motivations among blood donors with reactive serologic tests for syphilis in São Paulo, Brazil. Ferreira SC, de Almeida-Neto C, Nishiya AS, Oliveira CD, Ferreira JE, Alencar CS, Levi JE, Salles NA, Mendrone A Jr, Sabino EC. Transfus Med. 2014;24:169-75.

ANEXO 26. Prevalence of Treponema pallidum DNA among blood donors with two different serologic tests profiles for syphilis in São Paulo, Brazil. Ferreira SC, de Almeida-Neto C, Nishiya AS, Di-Lorenzo-Oliveira C, Ferreira JE, Alencar CS, Levi JE, Salles NA, Mendrone-Junior A, Sabino EC. Vox Sang. 2014;106:376-8.

ANEXO 27. Risk of exposure to Chagas' disease among seroreactive Brazilian blood donors. Salles NA, Sabino EC, Cliquet MG, Eluf Neto J, Mayer A, Almeida Neto C, Mendonça MC, Dorlhiac-Llacer PE, Chamone DAF, Saéz-Alquezar A Transfusion 1996;36:969.

ANEXO 28. Ten-year incidence of Chagas cardiomyopathy among asymptomatic Trypanosoma cruzi-seropositive former blood donors. Sabino EC, Ribeiro AL, Salemi VM, Di Lorenzo Oliveira C, Antunes AP, Menezes MM, lanni BM, Nastari L, Fernandes F, Patavino GM, Sachdev V, Capuani L, de Almeida-Neto C, Carrick DM, Wright D, Kavounis K, Goncalez TT, Carneiro-Proietti AB, Custer B, Busch MP, Murphy EL; 
National Heart, Lung, and Blood Institute Retrovirus Epidemiology Donor Study-II (REDS-II), International Component. Circulation. 2013;127:1105-15.

ANEXO 29. A comprehensive protocol to evaluate the use of blood and its components in Latin America and the Caribbean. Pozo AE, Pérez-Rosales MD, Almeida-Neto Cd, Remesar MC, Cortes AD, Delgado RB, Mendrone A Jr, Sabino E. Rev Panam Salud Publica. 2015;37(6):435-41.

ANEXO 30. Evaluation of a high throughput method for the detection of mutations associated with thrombosis and hereditary hemochromatosis in Brazilian blood donors. Dionisio Tavares Niewiadonski V, Dos Santos Bianchi JV, de Almeida-Neto C, Gaburo N Jr, Sabino EC. PLoS One. 2015;10(5):e0125460.

ANEXO 31. The impact of policies to restrict the use of plasma containing products and apheresis platelets from female donors to mitigate transfusion related acute lung injury (TRALI) in Brazil. Blatyta PF, Custer B, Liu J, Mendrone-Junior A, Wright DJ, Leão SC, Lopes MI, Carneiro-Proietti AB, Sabino EC, de Almeida-Neto C; for the NHLBI Retrovirus Epidemiology Donor Study-II (REDSII), International Component. Transfus Apher Sci. 2013;48:15-20. 2 
ANEXO 32. A ramdomized trial do evaluate the use of text messaging. letter and telephone call reminders to improve return of blood donors with reactive serologic tests. Porto-Ferreira FA, de Almeida-Neto C, Murphy EL, Montebello SC, Nogeurira FAH, da Silva EMK, McFarland W, Custer PC. Transfusion 2017 (no prelo). 


\section{Resumo}

de Almeida-Neto C. Estudos observacionais e de intervenção dentro de um hemocentro: implicações para as políticas e práticas na hemoterapia, [texto sistematizado]. São Paulo: Instituto de Medicina Tropical de São Paulo, Universidade de São Paulo, 2016.

No presente trabalho, foram apresentados e discutidos 32 manuscritos originais publicados entre 1996 e 2016. Os artigos, na sua maioria, abordam temas relacionados à segurança transfusional. Foram divididos, de maneira didática, em três áreas do ciclo do sangue: (1) Recrutamento, triagem e coleta; (2) Doenças transmissíveis por transfusão; (3) Uso racional dos hemocomponentes e outras pesquisas com doadores e receptores de sangue. Os manuscritos foram publicados em periódicos nacionais e internacionais e os resultados obtidos trouxeram significativa melhoria nos processos desenvolvidos no Hemocentro de São Paulo, e de outros serviços, muitas vezes, inclusive, aprimorando políticas nacionais de sangue. O hemocentro reúne condições adequadas para a realização de estudos observacionais e de intervenção em várias áreas da medicina. Com certa parcimônia, os achados destes estudos podem refletir as condições de saúde de uma determinada população e trazem benefícios para a saúde pública, para a comunidade e para o próprio doador.

Descritores: 1. Doadores de sangue. 2. Hepatite viral humana. 3. Sífilis. 4. HIV. 5. Síndrome de imunodeficiência adquirida. 6. Segurança transfusional. 7. Medicina transfusional 


\section{Summary}

de Almeida-Neto C. Observational and intervention studies in a blood center: implications to practices and policies in hemotherapy. [Sistemized text]. São Paulo: Instituto de Medicina Tropical de São Paulo, Universidade de São Paulo, 2016.

In this study, 32 original articles published between 1996 and 2016 are presented and discussed. Most of the articles address issues related to transfusion safety. They were divided, in a didactic way, in three areas of blood banking: (1) Recruitment, donation screening and collection; (2) Transfusion-transmitted disease; (3) Rational use of blood and components and other research with donors and blood recipients. The manuscripts were published in national and international journals and the results brought significant improvement in the processes developed at Hemocentro de São Paulo, and other blood banks, often improving national blood policies. The blood center has the appropriate environment to conduct observational and intervention studies in several areas of medicine. With some restrictions, the findings of these studies may reflect the health status of a given population and bring benefits to public health, the community and the donor himself/herself.

Descriptors: 1. Blood donors. 2. Viral hepatitis. 3. Syphilis. 4. HIV. 5. Acquired immunodeficiency syndrome. 6 . Transfusion safety. 7. Transfusion medicine 


\section{INTRODUÇÃO}

A média de coletas de sangue no Brasil realizadas entre 2010 e 2012 foi de 3.625 .081 procedimentos. Dos 3.637.775 procedimentos realizados no Brasil em 2012, 3.387.766 (93,13\%) foram coletas realizadas no SUS (Sistema Único de Saúde) e 250.009 (6,87\%) nos serviços exclusivamente privados. Os serviços de hemoterapia públicos são responsáveis por $61,43 \%$ da coleta de sangue no Brasil, seguidos dos serviços credenciados ao SUS, que respondem por $31,69 \%$, e dos serviços exclusivamente privados, que contribuem com $6,87 \%$ (1).

Os dados sobre as transfusões de sangue no Brasil apresentam para o ano de 2012 o quantitativo de 3.127 .957 procedimentos realizados. Esta produção refere-se à Hemorrede Pública Nacional, aos serviços filantrópicos e privados conveniados ao SUS e aos serviços exclusivamente privados, o que corresponde a um aumento de 148.144 (4,97\%) procedimentos em relação ao ano de 2011. Os serviços públicos foram responsáveis por $42,17 \%$ das transfusões de sangue no Brasil, os serviços credenciados ao SUS respondem por $46,38 \%$ e os serviços exclusivamente privados atingiram $11,44 \%(1)$.

O número de coletas de unidades de sangue e transfusões de sangue e hemocomponentes, por si só, demonstram a grandiosidade deste universo de estudo. 
Além disso, da mesma maneira que nas demais áreas da medicina, a hematologia e hemoterapia estão intimamente ligadas às demais disciplinas das áreas biológicas, humanas e exatas.

O chamado ciclo do sangue nada mais é do que um conjunto de processos que se inicia no recrutamento dos doadores de sangue e componentes, passando (i) pela triagem e coleta, (ii) pelo processamento em componentes, (iii) pelos testes de detecção de agentes transmissíveis pelo sangue, (iv) pelos testes imunematológicos, (v) pela desleucocitação e subsequente irradiação de produtos, (vi) pelo estoque e provas prétransfusionais, (vii) pelas indicações de transfusões, (viii) pela transfusão propriamente dita, (ix) pelo tratamento e prevenção de eventos adversos à transfusão e por fim a (x) pela retrovigilância. O objetivo de cada etapa deste ciclo é garantir a segurança do sangue vis-a-vis, ou seja, da veia do doador para a veia do receptor, corroborando com o princípio Hipocrático da não-maleficiência (Primum non noncere).

Diante do exposto, é possível reconhecer os serviços de hemoterapia como um universo propício a estudos observacionais ou de intervenção. Os processos do ciclo do sangue são regulamentados minimamente por legislações específicas e os dados de doadores, processos, transfusões e reações adversas estão registrados em bases de dados. Ademais, há interação de várias áreas das ciências entre os profissionais destes serviços, e, por fim, os hemocentros têm como missão a divulgação de conhecimento e aprimoramento dos serviços oferecidos à comunidade.

Certamente os achados em doadores de sangue não representam aqueles que são encontrados na população geral, tendo em vista que doadores devem preencher 
alguns pré-requisitos para ser elegíveis à doação. Por outro lado, muitas vezes estes achados podem ser úteis para apontar tendências na população geral. Exemplo disso são as situações de risco acrescido na população de doadores de sangue jovens, as quais podem refletir as mesmas condições que são observadas na população de jovens, em geral. Verifica-se, portanto, que a população de doadores pode servir como uma "população sentinela". Da mesma maneira, receptores de sangue podem apresentar eventos adversos que chamem a atenção tanto para novas doenças, ou novas fontes de infecção, como para doenças emergentes. Cabe, a título de exemplo, citar o primeiro caso de AIDS por transfusão, descrito em uma criança de 20 meses em 1983 (2) ou, ainda, a transmissão do vírus da zika em receptores de sangue (3).

Neste texto sistematizado, tenho a intenção de analisar criticamente 32 artigos originais nos quais fui autor ou coautor nos últimos 20 anos. A fim de tornar esta análise mais didática, os artigos serão discutidos de acordo com a minha linha de pesquisa, focada na segurança transfusional em três áreas do ciclo do sangue:

1. Recrutamento, triagem e coleta;

2. Doenças transmissíveis por transfusão;

3. Uso racional do sangue e hemocomponentes e outras pesquisas com doadores e receptores de sangue.

Os conhecimentos de cada um destes estudos, publicados em periódicos nacionais e internacionais, trouxeram significativa melhoria nos processos desenvolvidos no Hemocentro de São Paulo, assim como nos processos de outros serviços, muitas vezes, 
inclusive, aprimorando políticas de sangue nacionais. Cada um destes artigos tem uma história, cada uma delas será apresentada neste texto sistematizado.

Um dos meus mentores da Universidade da Califórnia sempre perguntava aos alunos o porquê de se fazer pesquisas na hematologia ou hemoterapia. As respostas eram diversas, tais como, "para ajudar a humanidade", "este é o meu trabalho", "por curiosidade", "para ficar famoso", "para fazer descobertas" e até "para ficar rico". Minha resposta para esta questão talvez seja mais prosaica: sempre gostei de fazer pesquisas porque é divertido. Dentro das minhas atividades médicas assistências, sempre aproveitei o tempo livre para pensar em pesquisas, seja junto dos meus alunos, residentes e colegas, seja junto dos meus professores. Confesso que pesquisar nunca foi um fardo para mim. Ao contrário, sempre extraí bons momentos desta convivência acadêmica. Neste texto sistematizado, elaborado de forma crítica, espero que consiga contar um pouco da minha história e da história da hemoterapia nos últimos 20 anos de uma maneira divertida para os colegas, para os professores e para a comunidade como um todo. 


\section{RECRUTAMENTO, TRIAGEM E COLETA}

\section{2a. Temporalidade e intervalos das doações de sangue}

A Portaria no 158 de 04 de fevereiro de 2016 (4) estabelece em seu artigo 30 que "A doação de sangue deve ser voluntária, anônima e altruísta, não devendo o doador, de forma direta ou indireta, receber qualquer remuneração ou benefício em virtude da sua realização." O recrutamento de doadores de sangue tem por finalidade garantir a coleta de sangue e componentes com qualidade e em quantidade necessária para suprir as demandas dos receptores.

O recrutamento e fidelização de doadores de sangue é uma necessidade mundial. A Organização Mundial da Saúde estima que, nos países desenvolvidos, 3,8\% da população doe sangue (5) para suprir as necessidades crescentes por transfusões. No Brasil, atualmente $1,9 \%$ de nossa população doa sangue (1). O maior número de procedimentos de alta complexidade em saúde, assim como o envelhecimento da população, aumentam a demanda por transfusões. Por outro lado, o envelhecimento populacional e a contínua implementação de restrições à doação, visando o risco zero nas transfusões, têm diminuído a oferta de hemocomponentes doados. 
Tendo em vista tal cenário, um dos aspectos que abordamos sobre esta questão foi a distribuição temporal de doações de sangue em três hemocentros brasileiros (6), por meio de um estudo transversal e temporal. O Projeto REDS-II Internacional (Retrovirus Epidemiology Donors Study) criou as condições necessárias para o agrupamento das bases de dados dos maiores hemocentros brasileiros, localizados em São Paulo, Recife, Belo Horizonte e Rio de Janeiro, os quais perfazem mais de 400.000 doações ao ano (7). O estudo da distribuição temporal de doadores examinou, no período de quatro anos, o número de doações semanais nos hemocentros de São Paulo, Belo Horizonte e Recife, comparando semanas com e sem feriados. Nossa hipótese era a de que possivelmente haveria variações no número de doações relacionadas aos feriados e a Semana do Doador.

A distribuição sazonal no número de doações entre 2007 e 2010, via de regra, mostrou um decréscimo nos feriados como Carnaval e Natal e um incremento na "Semana do Doador". Esta variação ocorreu de maneira distinta nos hemocentros participantes, sendo mais acentuada em Recife e Belo Horizonte do que em São Paulo. O estudo mostrou flutuações no número de doações nos principais hemocentros brasileiros ao longo do ano e permitiu analisar o comportamento desta flutuação em cada centro. A partir desta análise, foi possível prever a chance de desabastecimento de hemocomponentes em cada hemocentro durante cada período do ano. Campanhas de recrutamento de doadores, realizadas por meio de mensagens de texto, cartas ou telefonemas, foram programadas para prevenir a falta de hemocomponentes em cada um dos feriados com baixo número de doações. 
Da mesma maneira, no Hemocentro de São Paulo, foram discutidas estratégias para evitar um número excessivo de doações na "Semana do Doador". Quando o número de doações é muito concentrado em um determinado período, correm-se dois riscos. Primeiramente, concentrados de hemácias acabam sendo descartados devido à perda da validade, principalmente aqueles de outros tipos sanguíneos que não $\mathrm{O}$. Em segundo lugar, os doadores que realizaram sua doação num mesmo período ficam incapacitados a doar novamente por 60 (homens) a 90 (mulheres) dias. Consequentemente, haverá um período no qual há desabastecimento por incapacidade temporária dos doadores de voltar a doar. Nesses casos, doadores de primeira vez serão necessários para preencher o período de descontinuidade.

O manuscrito Interdonation intervals and patterns of return among blood donors (8) avaliou, por meio de uma coorte retrospectiva, a frequência de doações, as características demográficas e o intervalo de retorno entre doadores de primeira-vez e de repetição, e entre doadores altruístas e vinculados, nos hemocentros de São Paulo, Recife e Belo Horizonte. Todos os doadores de sangue e plaquetas alogênicos de 2007 foram seguidos por um intervalo de dois anos. No total, quase um milhão de doações foram analisadas. Cerca de $40 \%$ das doações eram provenientes de doadores de primeira vez e o restante de doadores de repetição. Ao longo do seguimento, aproximadamente $30 \%$ dos doadores de primeira vez e $60 \%$ dos doadores de repetição retornaram para nova doação. O intervalo médio foi de seis meses e menor em homens (182 e 171 dias em homens vs. 212 e 200 dias em mulheres para doadores de primeira-vez e de repetição). Doadores de primeira vez homens (OR=1,17; 95\% IC, 1,13-1,20), altruístas ( $\mathrm{OR}=2,26 ; 95 \% \mathrm{IC}, 2,20-2,33)$, e idade menor ou igual a 24 anos 
$(\mathrm{OR}=0,62-0,89$ para doadores $\geq 24$ anos) são mais propensos a voltar a doar. Preditores de retorno em doadores de repetição foram: sexo masculino $(\mathrm{OR}=1,35$; 95\% IC, 1,321,39), idade de 35 anos ou mais ( $O R=1,08-1,18$ vs. $\leq 24$ anos) e doadores altruístas $(\mathrm{OR}=2,39 ; 95 \% \mathrm{IC} 2,33-2,44)$. Recife mostrou uma maior taxa de retorno quando comparado com São Paulo e Belo Horizonte.

As taxas de retorno observadas nos doadores de primeira vez dos nossos hemocentros foram semelhantes às descritas por outros autores nos Estados Unidos da América (EUA) $(9,10)$ e inferiores às descritas na Noruega $(11)$, mas superiores às descritas na China (12). Observamos também que doadores que retornam em intervalos mais curtos apresentaram maior frequência de doações. Portanto, estratégias para incentivar doadores a retornar mais brevemente aos hemocentros e doarem mais frequentemente, assim como a criação de um ambiente propício para tornar a doação de sangue uma experiência agradável, são necessárias para a fidelização dos doadores e manutenção dos estoques em níveis adequados.

As diferenças regionais devem ser avaliadas separadamente. Por um lado, Recife mostrou uma maior taxa de retorno quando comparado aos demais hemocentros, mas é importante notar que em São Paulo e Belo Horizonte a oferta de serviços de coleta de sangue é muito maior do que em Recife. Por outro, as estratégias de recrutamento em Recife, baseadas nos médicos de família, servem como exemplo para outros hemocentros.

Embora os doadores altruístas apresentem maior chance de retorno do que os vinculados, nosso estudo demostrou, diferentemente do senso comum, que doadores 
vinculados também apresentam altas taxas de retorno, principalmente em Recife (Figura 1).

Figura 1. Probabilidade de retorno de doadores de primeira vez versus de repetição que realizaram ao menos uma doação de sangue total ou plaquetas em 2007 por hemocentro.

(A) todos doadores; (B) doadores altruístas; (C) doadores vinculados
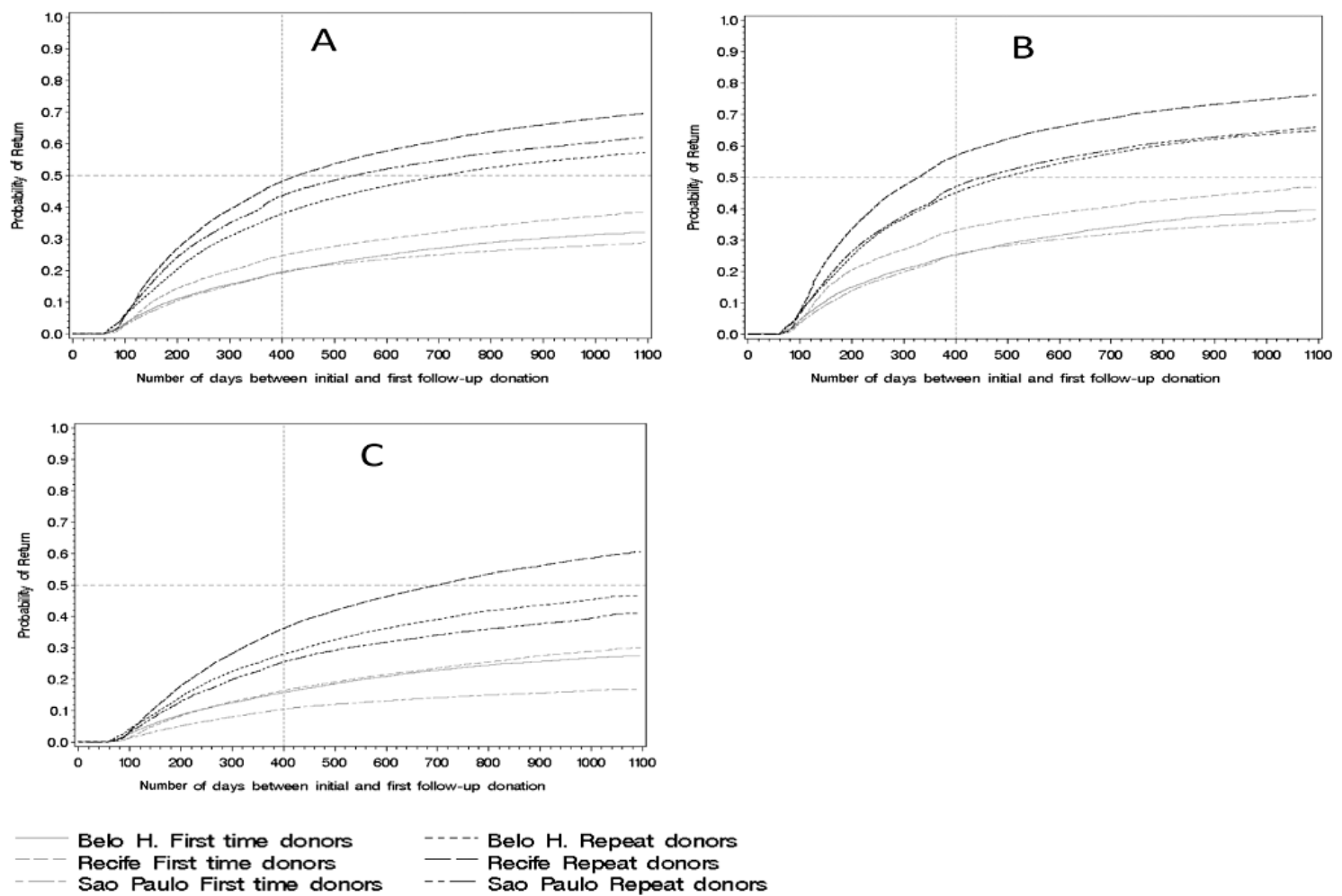

Concluímos, assim, que conhecer o padrão de retorno dos doadores é necessário para garantir que os estoques de sangue sejam adequados à demanda transfusional de cada hemocentro. Estratégias de comunicação são necessárias para transformar doadores vinculados em altruístas, bem como para tornar os doadores de primeira vez doadores de repetição. Doadores de reposição são mais suscetíveis à fidelização do que aqueles que não doam ou o fazem esporadicamente. Menos esforços são necessários para fidelizar doadores de reposição, uma vez que já conhecem o processo de doação. A 
motivação, a satisfação, a resposta a incentivos, o impacto da recusa e a ocorrência de eventos adversos nos doadores devem ser melhor estudados para aumentar cada vez mais a porcentagem de doadores na nossa população geral. Alguns destes pontos serão objetos de estudos que apresentaremos no presente trabalho.

\section{2b. Triagem hematológica de candidatos à doação de sangue}

O baixo valor da hemoglobina ou hematócrito na triagem de candidatos à doação é um dos principais motivos de recusa de doadores, especialmente em mulheres. Quando candidatos são recusados, há a perda potencial do doador e a perda de recursos dos hemocentros, perdas estas que se somam à tendência dos candidatos recusados de não tentar uma nova doação no futuro (13). Além disso, faz-se necessária a correta notificação e orientação deste candidato para o diagnóstico do motivo pelo qual a hemoglobina está baixa. Este motivo pode variar desde uma baixa de ferritina por aumento do fluxo menstrual, ou uma carência de ferro na dieta, até a presença de neoplasias hematológicas ou tumores sólidos infiltrando a medula óssea. Ainda que se trate de um cenário incomum, todos que trabalham há algum tempo em hemocentros com grande fluxo de doadores, devem ter presenciado, ao menos uma vez, candidatos com hemoglobina baixa e espessa camada de leucócitos, caracterizando a leucemia mieloide crônica assintomática.

Os níveis mínimos de hemoglobina ou hematócrito para a doação de sangue no nosso país são de $13 \mathrm{~g} / \mathrm{dl}$ ou $39 \%$ para homens e $12,5 \mathrm{~g} / \mathrm{dl}$ ou $38 \%$ para mulheres (4). Com o incentivo às doações de repetição, candidatos que realizam várias doações de sangue 
podem apresentar queda dos níveis de ferritina sérica e, consequentemente, dos níveis de hemoglobina ou hematócrito. A identificação adequada e precisa destes candidatos é importante para prevenir o agravamento da hipoferritinemia e/ou da anemia.

Não há consenso nos serviços de coleta de sangue sobre qual o melhor método para a triagem de candidatos. No estudo transversal Anemia screening in potential female blood donors: comparison of two diferente quantitative methods (14) avaliamos a sensibilidade e especificidade de dois métodos frequentemente utilizados na triagem hematológica, quais sejam (i) a deteç̧ão de hemoglobina pelo HemoCue 201 e (ii) a detecção do microhematócrito pelo HemataSTAT II, ambos a serem observados em candidatas à doação. Escolhemos realizar este estudo transversal em mulheres, que consistem na população de risco para recusa na triagem hematológica. Testamos 969 candidatas à doação pelos dois métodos e comparamos os resultados com uma amostra de sangue venoso analisada no ABX Pentra 60, ABX Diagnostic, método considerado padrão para detecção de anemia.

A sensibilidade do Hemocue 201 e HemataSTAT II para detectar anemia foi de $56 \%$ e $39,5 \%$ respectivamente $(p<0.001)$. Quando o candidato tinha hemoglobina menor do que $11 \mathrm{~g} / \mathrm{dl}$, a taxa de recusa foi de 100\% para o HemoCue 201 e 77\% para o HematoSTAT II. A especificidade dos métodos foi de 93,5\% e 93,2\% respectivamente. O HemoCue 201 mostrou maior poder de discriminação para detectar anemia em candidatas à doação (Figura 2), reduzindo o risco de exposição de mulheres anêmicas à doação de sangue sem aumentar a taxa de recusa de doadoras não-anêmicas. A 
porcentagem de doadoras corretamente elegíveis para doação de sangue foi de quase 90\% para ambos os métodos.

Os achados deste estudo nos permitem afirmar que o HemoCue 201 tem maior poder de identificar candidatas à doação com anemia do que o HemataSTAT II. Realizamos também uma análise de custos para a implantação do HemoCue 201 na triagem hematológica de doadores da Fundação Pró-Sangue. Na ocasião, o custo anual da triagem pelo HemoCue para 150.000 doações/ano foi 10 vezes maior do que o do HematoStat II. A implantação do HemoCue 201 traria um custo extra de U\$ 135.000/ano e detectaria 1.114 candidatas anêmicas a um custo de U\$ 121. Embora este não seja um investimento alto, considerando-se o risco de agravar e a necessidade de tratar a anemia em doadoras, não foi possível implantar rotineiramente o HemoCue 201 na nossa triagem hematológica por motivos financeiros. O uso do HemoCue como método confirmatório em candidatas com hematócrito entre 38\% e 39\% é uma estratégia que merece ser estudada.

Figura 2. Análise de regressão linear do HemoCue 201 versus hemoglobina (A) e do microhematócrito versus hematócrito venosos (B).
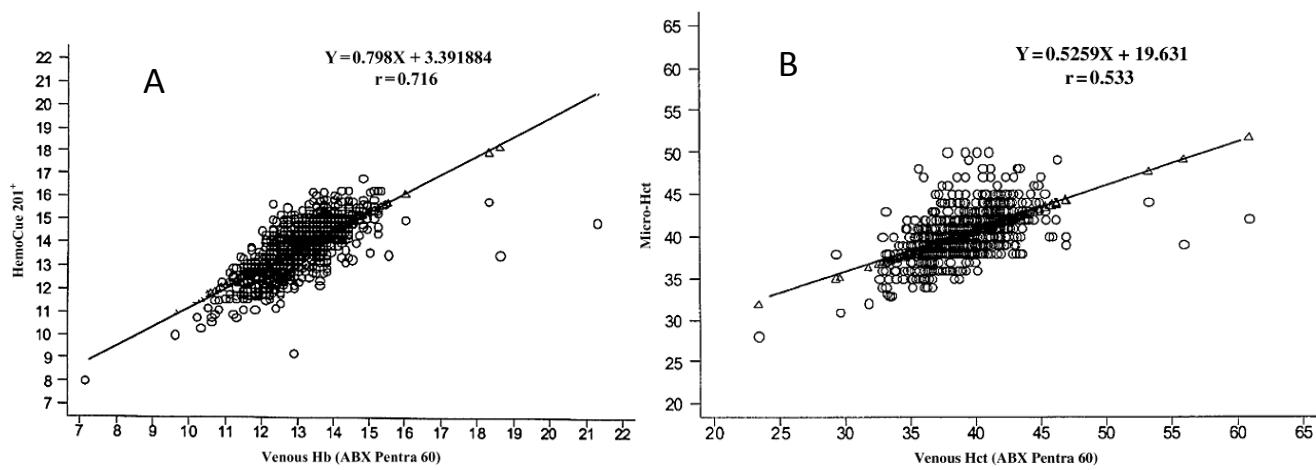

Posteriormente, conduzimos um estudo caso-controle para avaliar os fatores de risco para baixo hematócrito e depleção de ferro entre candidatos à doação de sangue. 0 
estudo Risk factors for deferral due to low hematocrit and iron depletion among prospective blood donors in a Brazilian Center (15) avaliou os fatores de risco para recusa devido ao hematócrito baixo e a depleção de ferritina em 400 doadores recusados (casos) e 456 doadores elegíveis (controles). O desenho do estudo teve como objetivo potencializar a detecção de causas de recusa na triagem hematólogica menos frequentes na população de doadores. Todos os participantes foram entrevistados quanto aos fatores de risco para anemia e testes laboratoriais adicionais, tais como a dosagem de ferritina sérica, foram coletados.

A análise multivariada demonstrou que candidatos mais prováveis de se recusados são os que recebem suplementação com ferro (OR=3,95; 95\%IC, 1,58-11,27), tomam ácido acetilsalicílico frequentemente $(\mathrm{OR}=4,08 ; 95 \% \mathrm{IC}, 2,45-7,06)$, referem dor de estômago $(\mathrm{OR}=1,75 ; 95 \% \mathrm{IC}, 1,26-2,44)$, melena (OR=2,73; 95\%IC, 1,49-5,22) ou hematoquezia $(\mathrm{OR}=3,01 ; 95 \% \mathrm{IC}, 1,48-6,52)$ e mulheres com mais do que um fluxo menstrual mensal (OR=4,14; 95\%IC, 1,45-14,96). Por outro lado, candidatos fumantes (OR=0,61; 95\%IC: 0,37-0,98) são mais prováveis de ser aceitos. Os fatores de risco para depleção de ferro são doação de repetição nos últimos 13 meses (OR=2,31; 95\%IC, 1,57-3,41) e ter sido recusado como doador anteriormente (OR=2,37; 95\%IC, 1,68-3,86). Fumantes $(\mathrm{OR}=0,56 ; 95 \% \mathrm{IC}, 0,34-0,92)$ e mulheres em menopausa ou histerectomizadas (OR=0,44; 95\%IC, 0,27-0,71) são menos suscetíveis a apresentar depleção de ferro.

Este estudo caso-controle detectou fatores de risco incomuns relacionados com a recusa de doadores na triagem hematológica e na depleção de ferro como o sangramento do trato gastrointestinal (TGI). Sangramento do TGI é um diagnóstico frequente tanto na clínica médico-cirúrgica como nos setores de emergência. Embora, 
o sangramento do TGI possua, na maioria das vezes, uma etiologia benigna, pode ser indicativo de um potencial sangramento com risco de morte ou de uma neoplasia, demandando uma investigação completa. Não obstante a atividade fim de um serviço de hemoterapia não seja fazer diagnósticos em candidatos à doação, a identificação precoce de sangramento do TGI em doadores recusados por baixo hematócrito ou hemoglobina pode facilitar o encaminhamento destes para diagnóstico e tratamento precoce.

Curiosamente, este estudo encontrou um efeito protetivo entre fumar e ser recusado por hematócrito baixo, e entre fumar e apresentar depleção de ferro. Este achado é controverso e havia sido reportado anteriormente por Cable et al. (16) no Estudo REDS-II nos EUA. Consideramos que o tabagismo pode ser um fator de confusão de outros hábitos conhecidos por elevar a ferritina, tais como vida sedentária e/ou uso regular de bebidas alcoólicas.

Os fatores de risco relacionados à recusa de doadores por baixo hematócrito e a deficiência de ferro identificados neste estudo podem contribuir para construir algoritmos para orientação, notificação e encaminhamento destes doadores. A experiência obtida ao longo dos anos com a notificação de doadores com sorologias alteradas pode ser utilizada para notificar e aconselhar doadores recusados por baixo hematócrito. Desta maneira, os serviços de hemoterapia incrementam seu relacionamento e confiança, tanto com os doadores como com a comunidade como um todo, aumentando seu reconhecimento pelos relevantes serviços públicos que presta. 
Dentro deste tema, desenvolvemos um terceiro estudo para avaliar o comportamento dos estoques de ferro em doadores de duplos concentrados de hemácias por aférese. No estudo antes-e-depois, uma variação de uma coorte retrospectiva, Impact of allogeneic 2-RBC apheresis on iron stores of Brazilian blood donors, (17) avaliamos em 96 doadores masculinos, entre 18-60 anos, os níveis de hemoglobina, hematócrito, volume corpuscular médio, hemoglobina corpuscular média, concentração da hemoglobina corpuscular média, ferro sérico, saturação da transferrina, capacidade total de ligação do ferro e ferritina sérica antes da doação de duplos concentrados de hemácias, dois e quatro meses após a doação. Estudamos estes tempos pois doadores masculinos de duas unidades de concentrados de hemácias são aptos a voltar a doar sangue total ou duplos concentrados de hemácias após quatro meses. Na ocasião, a Resolução da Diretoria Colegiada no 153 de 14 de junho de 2004 (18) preconizava a doação de duplos concentrados de hemácias para candidatos com $60 \mathrm{~kg}$ ou mais e nível de hemoglobina maior ou igual $13 \mathrm{~g} / \mathrm{dl}$, o que seria equivalente ao hematócrito de $39 \%$.

Observamos sintomas de hipocalcemia em cinco doadores $(9,8 \%)$ quando utilizamos o equipamento $\mathrm{MCS}^{+}$na coleta de duplos concentrados de hemácias, e em três $(6,7 \%)$, quando utilizamos o sistema Trima Accel. Encontramos um decréscimo estaticamente significante nos níveis de ferritina dois e quatro meses após a doação $(p<0,001)$ (Figura 3). 
Figura 3. Níveis de ferritina antes e 2 e 4 meses depois da doação de duplos concentrados de hemácias

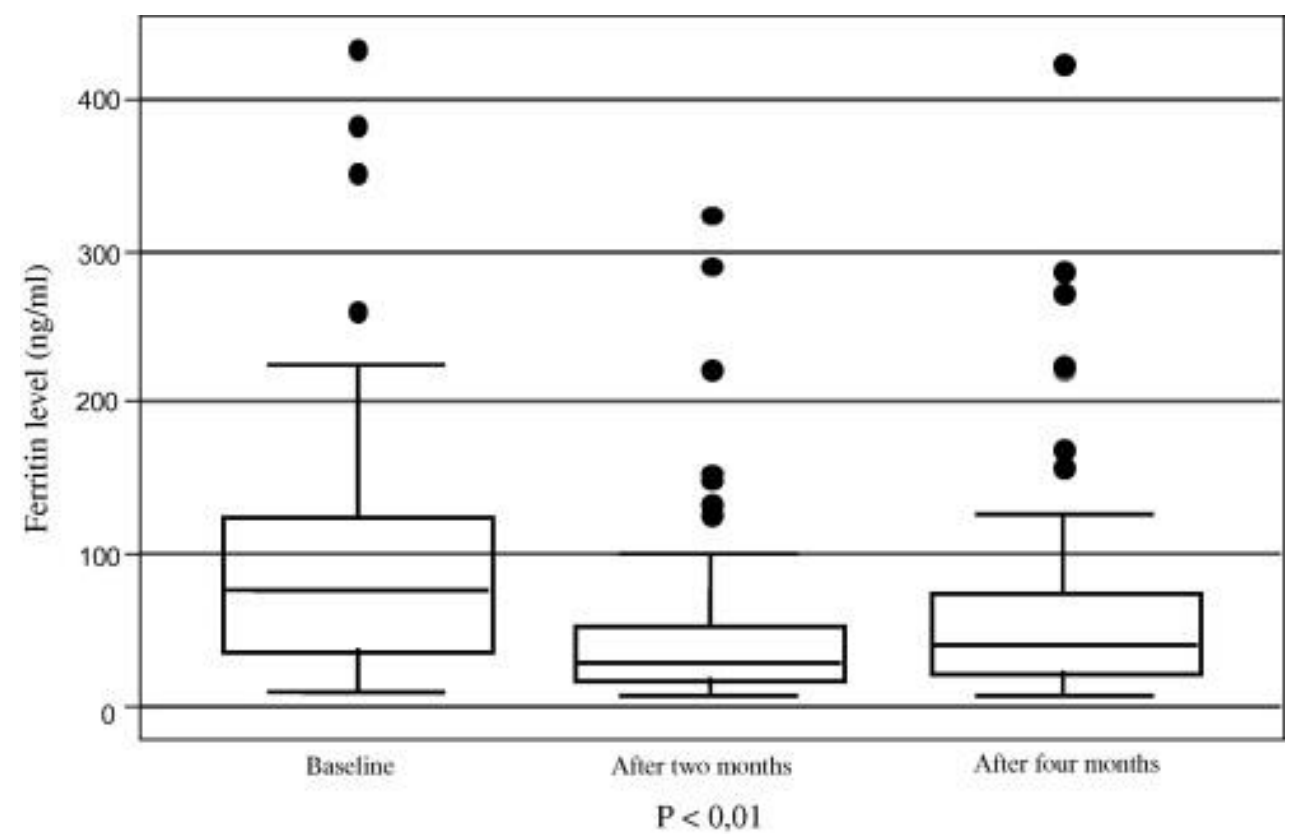

Antes da doação por aférese, $6,2 \%$ dos doadores apresentavam ferritina menor do que 15ng/ml. Dois e quatro meses após, $19,8 \%$ e $12,5 \%(p<0,01)$. Anemia foi identificada após dois e quatro meses em, respectivamente, $6,2 \%$ e $4,2 \%$ dos doadores. Numa análise de subgrupo, selecionamos doadores com $70 \mathrm{~kg}$ ou mais e hemoglobina maior ou igual a $14 \mathrm{~g} / \mathrm{dl}$ para verificar se o impacto nos estoques de ferro e incidência de anemia seria menor nesta população. Antes da doação, 1,4\% destes apresentavam ferritina menor do que $15 \mathrm{ng} / \mathrm{ml}$, e dois e quatro meses após a doação, $18,6 \%$ e $10 \%$ $(p=0,003)$. Um doador apresentou anemia $(1,4 \%)$.

Nesse sentido, concluímos que a doação de duplos concentrados de hemácias por aférese é um processo seguro com baixa incidência de eventos adversos imediatos. Entretanto, o intervalo de quatro meses após a doação não foi suficiente para repor os estoques de ferro em níveis pré-doação. Portanto, os serviços de hemoterapia devem 
considerar a possibilidade de restringir a doação de duplos concentrados de hemácias para doadores com maior volume sanguíneo e nível de hemoglobina mais alto. Em 13 de junho de2011, a Portaria no 1.353 do Ministério da Saúde estabeleceu no seu Artigo 101 que o doador deve ter pelo menos $70 \mathrm{~kg}$ e nível de hemoglobina superior a $14 \mathrm{~g} / \mathrm{dl}$ para a doação de duplos concentrados de hemácias (19).

\section{2c. Triagem clínica de doadores de sangue e voto de autoexclusão}

A triagem clínica tem por princípio garantir a segurança do doador e do receptor. A recusa de candidatos à doação de sangue com risco de transmissão de doenças é um dos pilares da triagem clínica. O risco da transmissão de doenças por transfusões está presente quando a doação é feita no período de janela imunológica ou quando algum patógeno não pode ser detectado através de testes laboratoriais de triagem. Entretanto, deve haver um equilíbrio nos critérios de triagem; se estes forem muito rígidos, muitos doadores podem ser recusados e os estoques podem ficar comprometidos. Ao mesmo tempo, se os critérios forem muito flexíveis, receptores podem correr riscos de adquirir doenças por transfusões. Ainda, se os critérios de triagem não forem justos, muitos candidatos podem omitir informações para não serem recusados.

O manuscrito Number of recente sexual partners among blood donors in Brazil: associations with donor demographics, donation characteristics, and infectious disease markers (20) apresenta um estudo transversal que avaliou, em 689.868 registros de doações nos hemocentros de São Paulo, Belo Horizonte e Recife, a correlação entre 
números de parceiros heterossexuais em 12 meses, características demográficas dos doadores e a prevalência de marcadores sorológicos para HIV, anti-HBc, sífilis, HTLV1/2 e hepatite $C(\mathrm{HCV})$. O número de parceiros sexuais nos últimos 12 meses que gerava recusa na ocasião era mais do que seis em São Paulo, mais do que três em Recife e mais do que dois em Belo Horizonte.

A grande maioria dos doadores referiu ter tido um ou nenhum parceiro sexual nos últimos 12 meses. Características demográficas associadas com o maior número de parceiros sexuais foram: sexo masculino ( $p<0,001$ em São Paulo e Recife), doadores mais jovens $(p<0,001)$, afrodescendentes $(P<0,001$ em São Paulo), doadores de primeira vez $(p<0,001)$ e maior nível educacional $(p<0,001)$. Marcadores sorológicos para HIV e sífilis foram associados com maior número de parceiros sexuais em São Paulo e Recife $(p<0,001)$, mas não em Belo Horizonte. A figura 1 apresenta a associação de marcadores para HIV, sífilis, anti-HBC e marcadores sorológicos em geral de acordo com cada hemocentro e número de parceiros sexuais.

$\mathrm{Na}$ análise de regressão logística, o número de parceiros heterossexuais recentes foi associado com a reatividade nos marcadores sorológicos para doenças transmissíveis por transfusão $(A O R=1,2-1,5)$, especialmente para o HIV $(A O R=1,9-4,4)$.

Este é o primeiro estudo publicado que sugere que triar candidatos à doação de sangue com base no número de parceiros sexuais recentes contribui para segurança transfusional. Constatamos que doadores homens mais jovens possuem maior número de parceiros sexuais, achado que vai ao encontro de grande parte dos dados publicados em relação à população geral. O número de recusas, entretanto, pode 
aumentar caso critérios mais rígidos em relação ao número de parceiros sejam adotados, devendo os hemocentros basear seus critérios de acordo com as características regionais de cada um.

Figura 4. Marcadores de doenças transmissíveis pelo sangue de acordo com centro e número de parceiros sexuais. (A) Duas reatividades para HIV; (B) testes de triagem para sífilis; (C) teste de triagem para anti-HBc; (D) marcadores sorológicos em geral (dois testes para HIV, HBsAg, HCV, HTLV-1/2, e triagem para sífilis e anti-HBC)
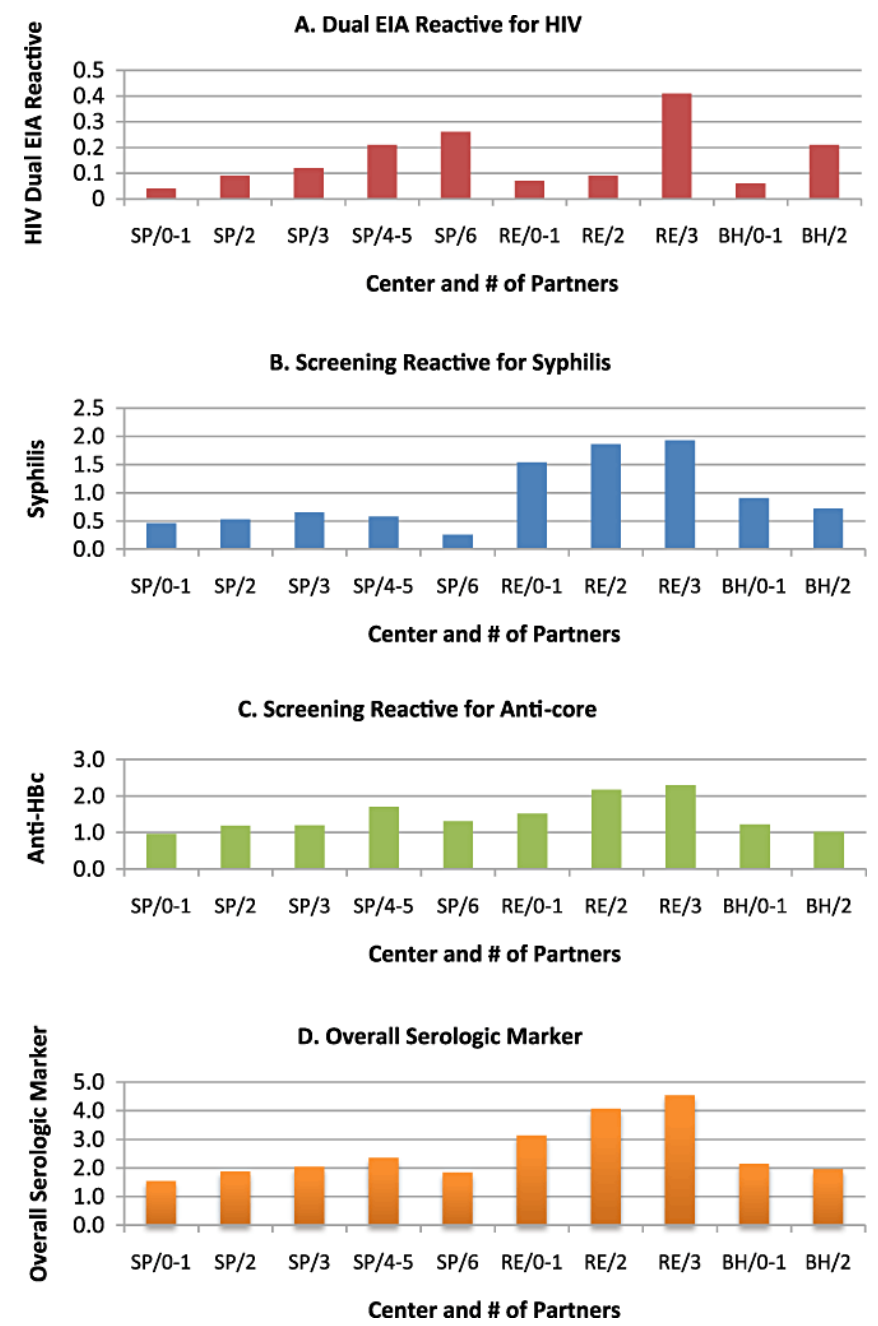
No hemocentro de São Paulo, após a publicação deste estudo, a diretoria, em conjunto com o corpo clínico, estabeleceu que doadores com mais de três parceiros nos últimos 12 meses deveriam ser recusados. Trata-se de norma interna vigente nos dias atuais.

Uma das últimas barreiras para evitar a transfusão de hemocomponentes provenientes de doadores expostos a risco acrescido de infecção pelo HIV é o voto de autoexclusão. Cada doador responde de maneira confidencial a uma pergunta sobre risco de exposição ao HIV (Figura 5). Caso o doador se autoexclua, a unidade doada é descartada. No hemocentro de São Paulo, visando aumentar a segurança do processo, uma vez que o doador se autoexcluía, todas as suas doações subsequentes também eram descartadas. No nosso serviço, 2,5\% das unidades doadas eram descartadas por testes sorológicos alterados e $4 \%$ devido à autoexclusão.

O estudo transversal Demographic characteristics and prevalence of serologic markers among blood donors who use confidential unit exclusion (CUE) in São Paulo, Brazil: implications for modification of CUE policies in Brazil (21) avaliou o perfil demográfico e a prevalência de marcadores sorológicos em doadores que se autoexcluíram. Por ocasião do estudo, o voto de autoexclusão era obrigatório em todos os serviços de coleta de sangue. Realizamos uma análise transversal das doações efetuadas entre julho de 2007 e junho de 2009, verificando a associação entre a autoexclusão de doadores e a reatividade confirmada para marcadores sorológicos. Também avaliamos os dados retrospectivos de 10 anos de doadores que se autoexcluíram, antes do período estudado, para verificar se a política de exclusão definitiva em voga no hemocentro de São Paulo era eficaz. 
No período estudado (julho de 2007 a junho de 2009), foram realizadas 265.550 doações originadas de 181.418 doadores, sendo que $3,6 \%$ das unidades doadas foram descartadas devido à autoexclusão; $1,1 \%$ durante o período estudado e $2,5 \%$ devido a autoexclusão anterior ao período estudado. A taxa de autoexclusão foi maior em doadores com menos de oito anos de estudo (OR=2,78; 95\%IC, 2,51-3,08) e de primeira vez $(\mathrm{OR}=14,9 ; 95 \% \mathrm{IC}, 13,7-16,2)$. Doadores que se autoexcluíram durante o período de estudo apresentaram maior prevalência de marcadores sorológicos reativos (OR=1,41;95\%IC, 1,13-1,77), enquanto aqueles que haviam se autoexcluído no passado não (OR=1,04; 95\%IC, 0,75-1,45).

Figura 5. Computador com tela de toque mostrando o voto de autoexclusão na pré-coleta do hemocentro de São Paulo

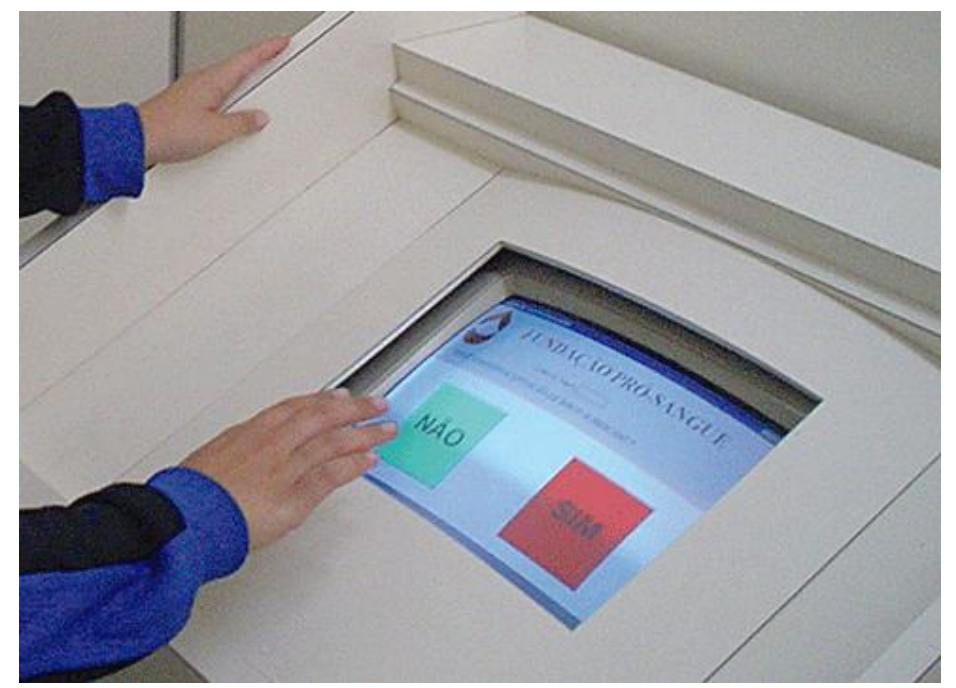

O nosso processo de autoexclusão parece não ser compreendido por todos os doadores, haja vista a maior taxa de autoexclusão em doadores de primeira vez e com menor nível educacional. No momento do voto de autoexclusão, existe uma associação com marcadores sorológicos alterados. Contudo, não há benefícios em 
descartar cumulativamente unidades doadas por indivíduos que se autoexcluíram no passado. Desta maneira, o descarte cumulativo devido ao voto de autoexclusão foi abolido no nosso serviço, trazendo um ganho de mais de $2 \%$ de unidades doadas. Além disso, com a implantação da tecnologia de ácidos nucleicos para triagem do HIV e HCV, o voto de autoexclusão deixou de ser obrigatório no nosso país (4).

\section{2d. Orientações educacionais na doação, motivação de doadores e capital social}

O primeiro estudo de intervenção que realizamos buscou avaliar o impacto de um panfleto educacional para informar doadores de sangue acerca do risco de se doar no período de janela imunológica do HIV (22). Comparamos esta intervenção com o procedimento padrão do hemocentro de São Paulo e medimos as taxas de recusa na triagem clínica, desistências, autoexclusões e positividade sorológica tanto no grupo dos doadores que receberam o material, como no grupo dos que não receberam o panfleto. O panfleto de três páginas abordava os seguintes conceitos: (i) Faça o teste do HIV no lugar correto (havia uma lista de endereços de Centros de Testagem e Aconselhamento-CTAs); (ii) Honestidade salva vidas (havia uma explicação sucinta sobre o risco de se doar no período de janela imunológica); (iii) Ajude-nos a não cometer um erro. A única maneira de se evitar transmissão do HIV para o receptor é respondendo honestamente as perguntas da triagem (explicação sobre a possibilidade de transmissão do HIV mesmo em unidades testadas).

Os panfletos foram distribuídos em meses alternados. Nos meses de distribuição, o material foi entregue pessoalmente para todos os candidatos no momento do teste do 
microhematócrito. Nos meses de pesquisa, após a doação, distribuímos um breve questionário, anônimo, com duas perguntas sobre dados demográficos (sexo e grau educacional) e duas perguntas, sobre HIV e transfusão, para serem respondidas como "Verdadeiro" ou "Falso". As duas questões eram: (1) Pessoas infectadas pelo HIV podem apresentar teste negativo dentro dos primeiros 15 dias após infecção? (2) No caso dessa pessoa doar sangue nestes 15 dias, quem receber a transfusão será contaminado pelo HIV? As duas afirmações foram consideradas como verdadeiras.

Entre agosto e novembro de 2007, avaliamos 33.940 doadores. Um efeito estatisticamente significante do panfleto foi a maior porcentagem de respostas certas na pesquisa pós-doação $(p<0,001)$. Tanto para a primeira $(68,1 \%$ vs. $52,9 \%)$ como para a segunda $(91,1 \%$ vs. $87,2 \%)$ pergunta houve mais respostas corretas nos meses em que o panfleto foi distribuído. O efeito do panfleto foi maior em doadores com mais de oito anos de estudo. Ao mesmo tempo, não houve, contudo, nenhum impacto significante do panfleto nas porcentagens de recusa clínica de doadores na triagem, na autoexclusão e na prevalência de marcadores sorológicos reagentes.

Nossos resultados demonstram que é possível aumentar o conhecimento dos doadores, por meio de uma orientação por escrito, quanto aos riscos de doar sangue no período de janela imunológica. Entretanto, ferramentas de comunicação mais efetivas são necessárias para esclarecer doadores com menor nível educacional. A informação por si só não é suficiente para mudar o comportamento do doador. 0 conhecimento das motivações dos doadores que apresentam positividade no teste para o HIV talvez possa trazer novas ideias para abordar estes indivíduos e encaminhá- 
los de maneira correta para os CTAs. Mais adiante, vamos apresentar estudos que avaliaram fatores de risco e hábitos de vida em doadores soropositivos.

Seguindo esta linha de análise, o manuscrito Motivation and social capital among prospective blood donors in three large centers in Brazil (23) examinou a associação entre fatores motivacionais (altruísmo, interesse próprio, resposta ao apelo direto) e o capital social cognitivo e estrutural nos hemocentros de São Paulo, Recife e Belo Horizonte, participantes do Programa REDS-II Internacional. O capital social é definido sucintamente como "confiança, normas e rede de relacionamentos que facilitam a cooperação das pessoas em benefício mútuo". Pode ser dividido em dois tipos: cognitivo e estrutural. O capital social cognitivo avalia o conhecimento dos indivíduos quanto às organizações de uma sociedade e funciona como um código social para guiar nossas condutas. O capital social estrutural avalia como as pessoas participam ativamente destes grupos e associações.

Neste estudo transversal, avaliamos as respostas de 7.635 candidatos à doação por nos valendo de um questionário autoadministrado sobre motivações para doar e capital social dos participantes. Identificamos alto grau de altruísmo em 43,5\% dos participantes e resposta ao apelo direto em $41,7 \%$. Apenas $26,9 \%$ expressaram alto grau de interesse próprio. O mais alto grau de interesse próprio foi identificado em Recife $(41,7 \%)$. Entre os participantes, $37,4 \%$ apresentaram alto grau de capital social cognitivo, enquanto $19,2 \%$ apresentaram alto grau de capital social estrutural. Alto grau de capital social estrutural estava associado ao altruísmo interesse próprio e apelo direto. 
Em suma, nossos achados demonstram que a maior parte dos candidatos à doação são movidos pelo altruísmo e apelo direto. Embora os candidatos tenham um grande conhecimento das organizações sociais, não participam destas. Acreditamos que muitos candidatos à doação, semelhante ao que foi visto na população geral, têm descrédito nas instituições sociais. Desta maneira, os hemocentros necessitam promover a credibilidade dos serviços prestados à comunidade e programar estratégias de marketing a fim de oferecer maior transparência para seus usuários. Por fim, considerando a associação entre capital social estrutural e diferentes motivações para doar, campanhas de doação em clubes e associações são propensas a trazer um bom número de candidatos motivados a participar.

Posteriormente, nessa mesma linha de sociologia econômica, avaliamos a associação entre o capital social e buscadores-de-teste nos mesmos hemocentros acima estudados (24). O buscador-de-teste é definido como o individuo que doa sangue com vistas a ser testado para o HIV ou outras infecções. Ao invés de procurar centros de testagem, devido ao estigma social ou a alta credibilidade dos hemocentros, prefere ser testado por meio de sua doação. Tal fenômeno está associado, inclusive, a um dado histórico: no início da epidemia do HIV, os hemocentros eram os únicos lugares a realizar o teste para o HIV sem custo. Utilizando-se da pesquisa anteriormente descrita, incluímos duas questões diretas e uma indireta para identificar buscadoresde-testes e classificamos as respostas em: (i) não buscador-de-teste; (ii) possível; (iii) presumido e (iv) buscador-de-teste autodeclarado. O capital social foi novamente dividido em cognitivo e estrutural. 
Encontramos uma importante associação entre ser buscador-de-teste presumido ou autodeclarado e possuir alto capital social cognitivo. As razões de chance variaram de 2,3 (95\%IC, 1,3-3,9) naqueles com capital social intermediário até 7,4 (95\% IC, 4,2-13,3) naqueles com alto capital social cognitivo. Estes resultados são bem instigantes e úteis para nossos hemocentros. Os hemocentros brasileiros são muito dependentes da imagem que passam para a sociedade, pois, cultivando uma imagem positiva, podem arrecadar mais doações e manter seus estoques. Os buscadores-de-teste não mudarão seu comportamento a menos que acreditem que outras instituições, tais como os CTAs, são tão seguras e confiáveis como os hemocentros.

A solução para este dilema não parte somente dos hemocentros, e sim também dos CTAs. Estes últimos precisam oferecer serviços de maneira rápida, segura e confiável, de forma a trazer os buscadores-de-testes para receber seus cuidados. Os buscadoresde-teste possuem um conhecimento organizacional muito grande e os hemocentros devem estudar ações para direcioná-los para locais adequados. Um exemplo interessante que, de maneira intuitiva, vem sendo praticado pelos hemocentros brasileiros é a não emissão do certificado de doação, ou "carteirinha do doador". Até pouco tempo atrás, os hemocentros costumavam enviar o certificado 15-20 dias após a doação, enquanto os CTAs forneciam os resultados dos testes em 30 dias. Nossa proposta foi não mais emitir o certificado de doação e enviar uma carta de agradecimento ao doador no momento que estivesse apto a realizar uma nova doação. Além disso, foi acrescentada uma pergunta na triagem clínica para verificar se o candidato seria um buscador-de-teste autodeclarado. Consequentemente, estudos 
para verificar a eficácia destas estratégias são necessários para manter buscadores-detestes afastados dos hemocentros. 


\section{DOENÇAS TRANSMISSÍVEIS POR TRANSFUSÃO}

As questões que serão apresentadas e discutidas sobre as doenças transmissíveis pelo sangue, referem-se a estudos publicados sobre HIV, hepatites, sífilis e Doença de Chagas, entre 1996 e 2016.

\section{3a. Vírus da imunodeficiência humana}

O manuscrito A single window-period donation detected by human immunodeficency vírus p24 antigen after 5 years of routine screeening in a group of Brazilian blood banks (25), publicado em 2002, apresenta a experiência de cinco serviços de hemoterapia privados, situados na cidade de São Paulo, durante o período do uso do antígeno p24 (Agp24) para diminuir a janela imunológica para o HIV nas unidades de sangue total doadas. A triagem sorológica com o Agp24 tem o benefício de encurtar o período de janela imunológica em 5-10 dias em relação à triagem com testes imunoenzimáticos (EIA), de terceira geração, para detectar anticorpos anti-HIV (Figura 6).

No passado, o Agp24 era testes obrigatório na triagem sorológica dos bancos de sangue dos EUA. No Brasil, a partir do final dos anos 1980, a triagem sorológica para o 
HIV era feita através de dois EIAs distintos. Em 1999, Sabino et al. (26) estimaram que o risco residual da transmissão do HIV na cidade de São Paulo era dez vezes maior do que o reportado nos EUA e Europa. Portanto, métodos que pudessem diminuir o risco residual da infecção pelo HIV eram necessários em nosso meio. Durante 61 meses, entre maio de 1996 e junho de 2001, 103.470 doações consecutivas foram triadas para o antígeno p24 do HIV utilizando kits comercialmente disponíveis. No período, 58 amostras repetidamente reagentes foram identificadas $(0,056 \%$ do total de amostras testadas, 95\%IC. 0,004-0,016). Dez continuaram reagentes após o teste de neutralização $(0,010 \%$; 95\%IC, $0.004-0,016)$, nove eram concomitantemente anti-HIV (0,009\%; 95\%IC, 0,003-0,014) reagentes e somente uma anti-HIV EIA não-reagente (0,001\%; 95\% IC, 0-0,003).

O doador da amostra somente Agp24 reagente era um homem, de 25 anos, que posteriormente admitiu ter se exposto a situação de risco acrescido para o HIV, relatando contato sexual desprotegido com parceiro do mesmo sexo. No momento de sua doação, a carga viral do HIV RNA era alta (> 750.000 cópias/ml), portando o doador o HIV-1 "tipo selvagem", subtipo B. O doador relatou sintomas sugestivos de infecção viral aguda pelo HIV como diarreia, vômitos, febre e linfadenopatia cervical. Estas informações não foram descritas durante a triagem clínica, levantado a hipótese de que ele omitiu as informações a fim de doar sangue. Curiosamente, ele havia sido recusado em outro serviço, no mesmo dia em que doou, ao mencionar contato sexual com parceiro do mesmo sexo (dado não publicado). Uma nova amostra, colhida 22 dias após a doação, isto é, supostamente 56 dias após a infecção, foi Agp24 nãoreagente e anti-HIV EIA reagente em dois métodos distintos. 
Baseando-nos nestes dados, estimamos que o risco residual da infecção pelo HIV na população estudada foi de 1:23.809 sem a triagem pelo Agp24 e passou a 1:87.796 doações após introdução deste teste. Não acreditamos que a introdução do Agp24 possa ter causado o chamado "efeito magnético", ou seja, tenha atraído indivíduos de risco para doar. No caso, o doador AgP24 reagente não tinha conhecimento que sua amostra de doação havia sido submetida a este teste.

Em julho de 2001, a triagem pelo Agp24 foi substituída por um método "in house" para detectar o HIV RNA. Esta decisão foi baseada na estimativa que a Tecnologia de Ácidos Nucleico (NAT) HIV reduzisse em mais cinco dias a janela imunológica do HIV quando comparado ao Agp24. Além disso, o NAT-HIV apresentava custo menor e efetividade superior, sem aumentar a perda de hemocomponentes. Nossos dados mostraram o benefício de se tentar reduzir cada vez mais o período de janela imunológica do HIV por meio de testes laboratoriais, principalmente em países como o Brasil, que apresentam maior risco residual da transmissão de doenças por sangue. O caso apresentado ilustra a importância de buscar uma triagem clínica sensível para excluir candidatos em risco. Por fim, pudemos especular que a atitude deste doador era compatível com a de buscador-de-testes, pois, ao ser recusado num primeiro serviço, procurou outro local para doar e negligenciou informações relevantes na triagem clínica. 
Figura 6. Marcadores da infecção pelo HIV

Peak viremia: $10^{6}-10^{8} \mathrm{gEq} / \mathrm{mL}$

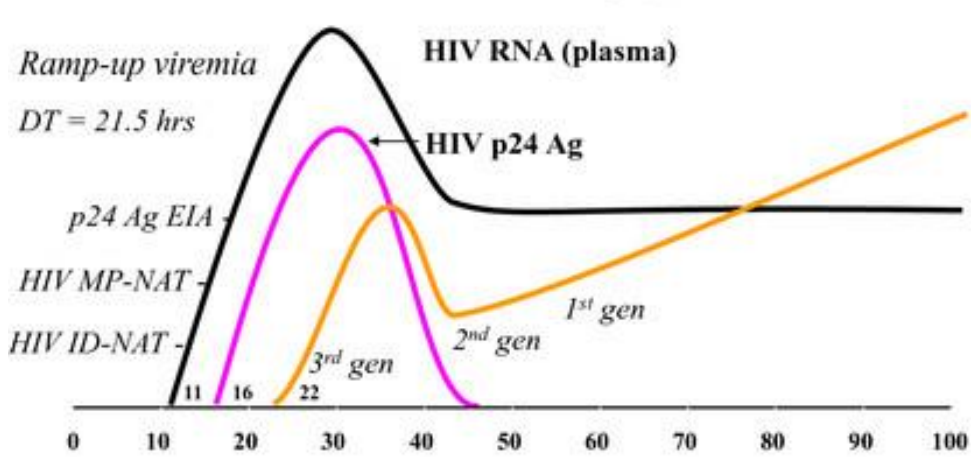

Referência: Testing for HIV - the first three decades (PDF Download Available). Available from: https://www.researchgate.net/publication/274903163_Testing_for_HIV__the_first_three_decades?_sg=U_4Jz3vAJDFQgAb2b_LbX5GGuytPCcxf_pB2MfyrHawQIDVcGOHvSWf16cbZ-oQnazgKHfbIVPaKwrveeZ4/6w [accessed Sep 19, 2016]

Até recentemente, a triagem sorológica de rotina para o HIV era realizada através de dois EIAs diferentes, realizados em paralelo, para detectar a presença de anticorpos anti-HIV. Em fevereiro de 2014, o teste de NAT-HIV foi adicionado à rotina de triagem sorológica. Em 2011, publicamos o manuscrito Performance of parallel screening of Brazilian blood donors with two human immunodeficiency virus immunoassays: implications for sequential immunoassay testing algorithms in other countries (27) com o objetivo de validar, a partir de um estudo transversal, o uso de dois testes imunoenzimáticos, em paralelo, para detectar a infecção pelo HIV. Posteriormente, poderíamos usar este padrão sorológico em estudos de incidência e prevalência do HIV em doadores de sangue.

Para isto, realizamos uma revisão dos resultados de testes de triagem e confirmatórios obtidos de 307.407 doações no ano de implantação do REDS-II Internacional no Brasil (2007) e de 2.304.755 doações coletadas entre 1996 e 2006 no Hemocentro de São Paulo. Em São Paulo, 11.410 (0,50\%) doações foram descartadas por reatividade em pelo menos um dos EIAs para anti-HIV. Destas, 2.095 (0,9\%) foram reativas em ambos 
os EIAs. O Western blot foi reativo em 1.002 (48\%) doadores que retornaram para repetir os exames e apresentavam dois ElAs reagentes na triagem sorológica. Apenas quatro doadores portadores do HIV, os quais doaram antes de 2002, não foram identificados pelos testes imunoenzimáticos. O valor preditivo positivo (VPP) de dois EIAs em paralelo variou de $45,8 \%$ para $100 \%$, com VPP de $80 \%$ a $90 \%$ quando foram usados ensaios de diferentes fornecedores. Nos casos em que ambos os EIAs apresentavam a densidade óptica sobre o limite de corte (S/CO) maior ou igual a três, o VPP variou de $91 \%$ a 99\%, com sensibilidade aproximadamente de $99 \%$.

Concluímos que quando ambos os ElAs, de diferentes fornecedores, são reagentes, com S/CO maior ou igual a três, constituem-se em marcadores sensíveis e específicos da infecção pelo HIV, podendo ser utilizados em estudos de prevalência. Nosso estudo apresentou uma análise sistemática de mais de 2,5 milhões de doações testadas por EIAs em paralelo. A testagem de EIAs para HIV em paralelo também foi utilizada em outros países além do Brasil, a exemplo da Austrália. Há vários algoritmos para testagem e diagnóstico do HIV, entretanto, nem todos foram submetidos a uma revisão ampla e sistemática como no nosso estudo. Posteriormente, utilizamos a duplicidade do EIAs para anti-HIV em paralelo como marcador de prevalência de infecção pelo HIV em outros estudos do REDS-II $(21,28)$.

As medidas adotadas para a diminuição do risco residual da transmissão do HIV por transfusão incluem novos testes sorológicos e de biologia molecular, recrutamento de candidatos com baixo risco de infeç̧ão pelo HIV, triagem clínica e notificação e orientação de doadores com sorologias alteradas. Mesmo com todas estas ações, há relatos da transmissão do HIV por transfusão durante o curto período de janela 
imunológica. Em 2012, estimamos que o risco da transmissão do HIV por transfusão de sangue era de 0,68:100.000 doações, utilizando a triagem sorológica por teste EIA de quarta geração e o NAT-HIV em minipools de seis amostras. Em 2013, Salles et al. (29) publicaram o relato da transmissão por transfusão do HIV em um receptor leucêmico de 47 transfusões de concentrados de hemácias e plaquetas. Todas as unidades haviam sido triadas conforme o algoritmo mencionado no parágrafo anterior. 0 doador responsável por esta contaminação foi identificado e apresentou soroconversão para o HIV. Ele era doador de repetição, havia doado três vezes no nosso hemocentro e negou fatores de risco para a infecção pelo HIV, tampouco se autoexcluiu. Este relato ilustra a limitação dos testes laboratoriais para prevenir a transmissão de patógenos pela transfusão, em especial o HIV.

Torna-se cada vez mais necessário entender o comportamento e motivações de nossos doadores, assim como promover facilidades para que doadores em risco não compareçam aos hemocentros para doar. Uma das maneiras de aumentar a nossa compreensão sobre este complexo tema é entrevistar doadores HIV positivos. Isto porque conhecer os fatores de risco que doadores negaram na triagem clínica pode melhorar os processos de seleção de doadores e a comunicação com estes indivíduos e, em última análise, a segurança transfusional.

Em 2007, publicamos um estudo caso-controle, em que doadores HIV positivos (casos) foram comparados com doadores que apresentaram resultado falso-positivo nos testes de triagem para HIV (controles) (30). Todos os participantes haviam apresentado resultados alterados por ocasião da doação e retornaram ao hemocentro para exames complementares confirmatórios, notificação e aconselhamento. No 
retorno, os participantes foram submetidos a uma entrevista, face-a-face, estruturada, de forma sistematizada, sobre situações de risco acrescido para o HIV. A entrevista não era "cega" e, para a função de entrevistador, foi designado um médico assistente, previamente treinado no atendimento de doadores soropositivos. Doadores com resultado falso-positivo para o HIV foram submetidos aos mesmos procedimentos dos confirmadamente positivos. Uma vez selecionados como controles têm a vantagem de prevenir o denominado "viés de lembrança" (recall bias).

Avaliamos 754.815 doações de sangue e 2.865 (0,38\%) unidades foram descartadas devido à sorologia reagente para o HIV em pelo menos um dos EIAs. Destas unidades, $2.023(70,6 \%)$ dos doadores retornaram para testes confirmatórios. Após os testes complementares, $1.731(85,6 \%)$ doadores eram reagentes em pelo menos um dos testes de EIA e forma submetidos ao Western blot. Do total, 320 (18,5\%) eram Western blot positivo, $281(16,2 \%)$ indeterminado e $1.120(65,3 \%)$ negativo. Dos 320 casos elegíveis, 272 (85\%) retornaram para notificação e aconselhamento e foram incluídos no estudo. Entre os 1.130 controles elegíveis, 468 (41,4\%) foram incluídos (Figura 7).

Os fatores de risco que teriam levado a recusa do doador na triagem clínica foram identificados em $48,9 \%$ dos casos e em $9,4 \%$ dos controles. Os fatores de risco identificados entre casos, em homens e mulheres, podem ser vistos na tabela 1.

Homem que manteve relação sexual com outro homem (HSH) foi o maior preditor de risco para a infecção em doadores de sangue. Entre mulheres, a exposição ao risco acrescido para HIV de seus parceiros foi o maior preditor da infecção. Metade dos 
casos admitiu ter se exposto ao risco acrescido de infecção pelo HIV e, de maneira inesperada, quase $10 \%$ dos controles. Entretanto, a ausência de fatores de risco na outra metade dos casos estudados pode ser explicada pela recusa destes doadores em admitir exposição ao risco para HIV devido ao estigma social ou ao receio de sofrer algum tipo de preconceito. É possível também que o padrão da infecção pelo HIV no Brasil esteja mudando, com aumento da infecção em populações sem um fator de risco evidente. Assim, um aprimoramento da triagem clínica, mais direcionada para fatores de risco encontrados entre homens e mulheres, é importante para diminuir o risco residual da transmissão por transfusão do HIV. A comunicação entre os triadores e os doadores deve ser transparente, sem demonstração de qualquer preconceito. As perguntas devem ser padronizadas, e sistematicamente aplicadas para todos os candidatos. Por fim, concluímos que os critérios de triagem devem ser razoáveis e justos, para evitar que doadores sejam propensos a omitir informações. A criação de roteiros pré-estabelecidos, seguidos por toda a equipe de triagem, pode ser útil para esclarecer os motivos de recusa clínica aos doadores e aumentar a confiabilidade dos candidatos às normas da triagem clínica. 
Figura 7. Fluxograma da triagem sorológica para HIV de doadores de sangue da

\section{Fundação Pró-Sangue entre janeiro de 1999 e dezembro de 2003}

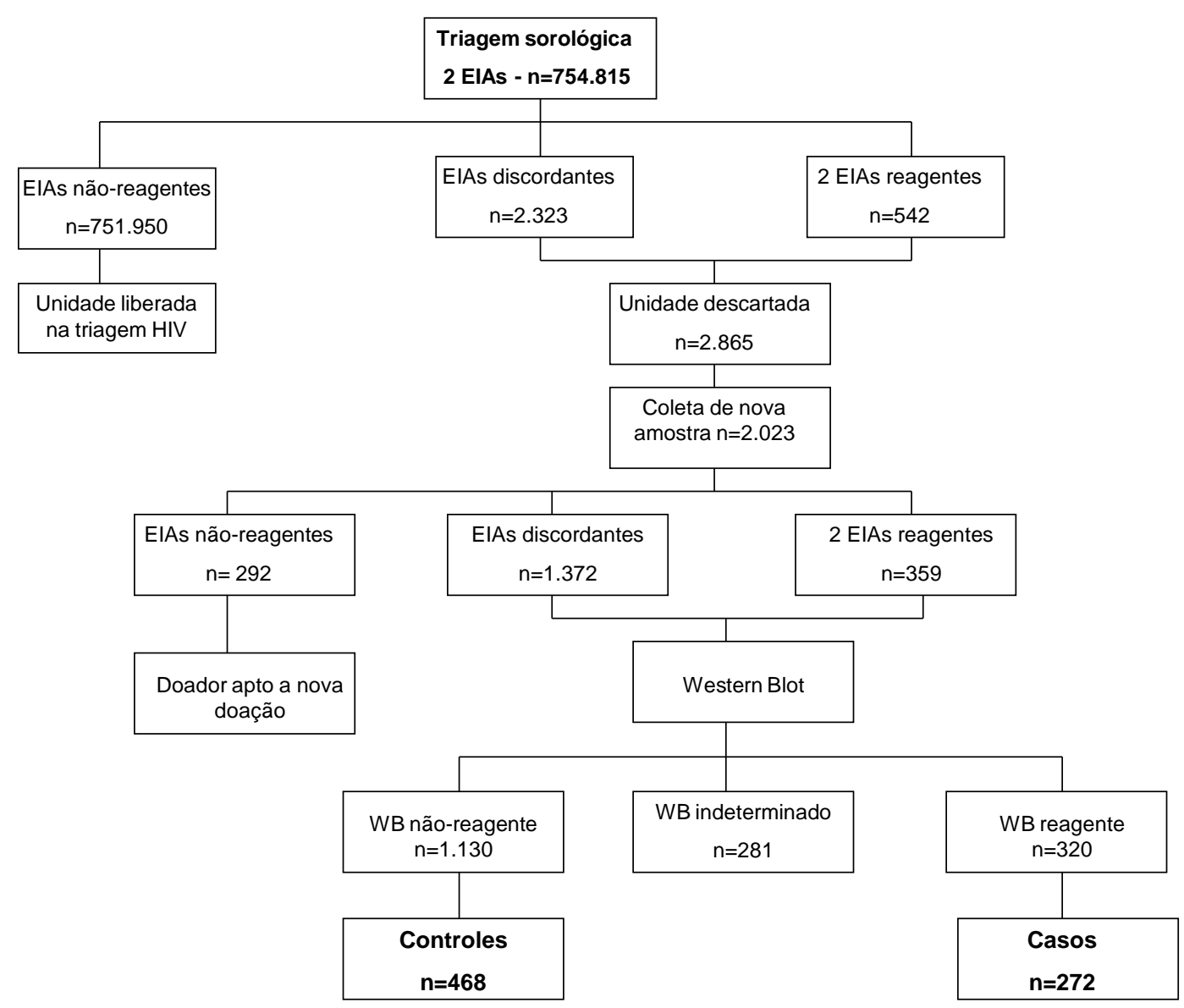


Tabela 1 - Correlações independentes da soropositividade do HIV numa população de doadores de sangue do sexo masculino e feminino da Fundação Pró-Sangue / Hemocentro de São Paulo - jan. 1999 e dez. 2003 (n=740)

VARIÁVEL

AOR (IC 95\%)

p

Sexo feminino

Parceiro sexual usuário de drogas

$12,4(1,3-120,2) \quad 0,03$

Parceiro sexual com $\geq 5$ parceiros ou sexo com prostituta

$13,0(2,7-63,2) \quad 0,002$

Parceiro sexual HIV positivo

$4,8(0,4-64,3)$

0,239

$\geq 2$ parceiros sexuais nos últimos 12 meses

$2,3(1,0-5,3)$

0,052

\section{Sexo masculino}

Homem que mantém/manteve relação sexual com outro

$26,2(7,8-87,4) \quad<0,001$

homem

Doença Sexualmente Transmissível prévia

$3,2(1,5-6,9)$

0,003

Pagou ou recebeu dinheiro por sexo nos últimos 12 meses

$2,1(1,0-4,2)$

0,039

$\geq 2$ parceiros sexuais nos últimos 12 meses

$2,3(1,4-3,6)$

0,001

Anti-HCV positivo*

$4,0(1,3-12,0)$

0,014

anti-HBc positivo $^{\dagger}$

$3,8(1,9-7,7)$

$<0,001$

\footnotetext{
* anticorpos contra o vírus da hepatite $\mathrm{C}$, confirmado por Imunoblot em nova amostra

${ }^{+}$anticorpos totais contra o core do vírus da hepatite $B$, repetidamente reativo em nova amostra
} 
Entrevistas para detectar comportamentos estigmatizados podem ter sua sensibilidade aumentada através do uso da autoentrevista estruturada e computadorizada com áudio e vídeo, ou Audio Computer-Assisted Structured Interviews (ACASI) (Figura 8).

Figura 8. ACASI utilizado para entrevistas na Fundação Pró-Sangue Hemocentro de São Paulo

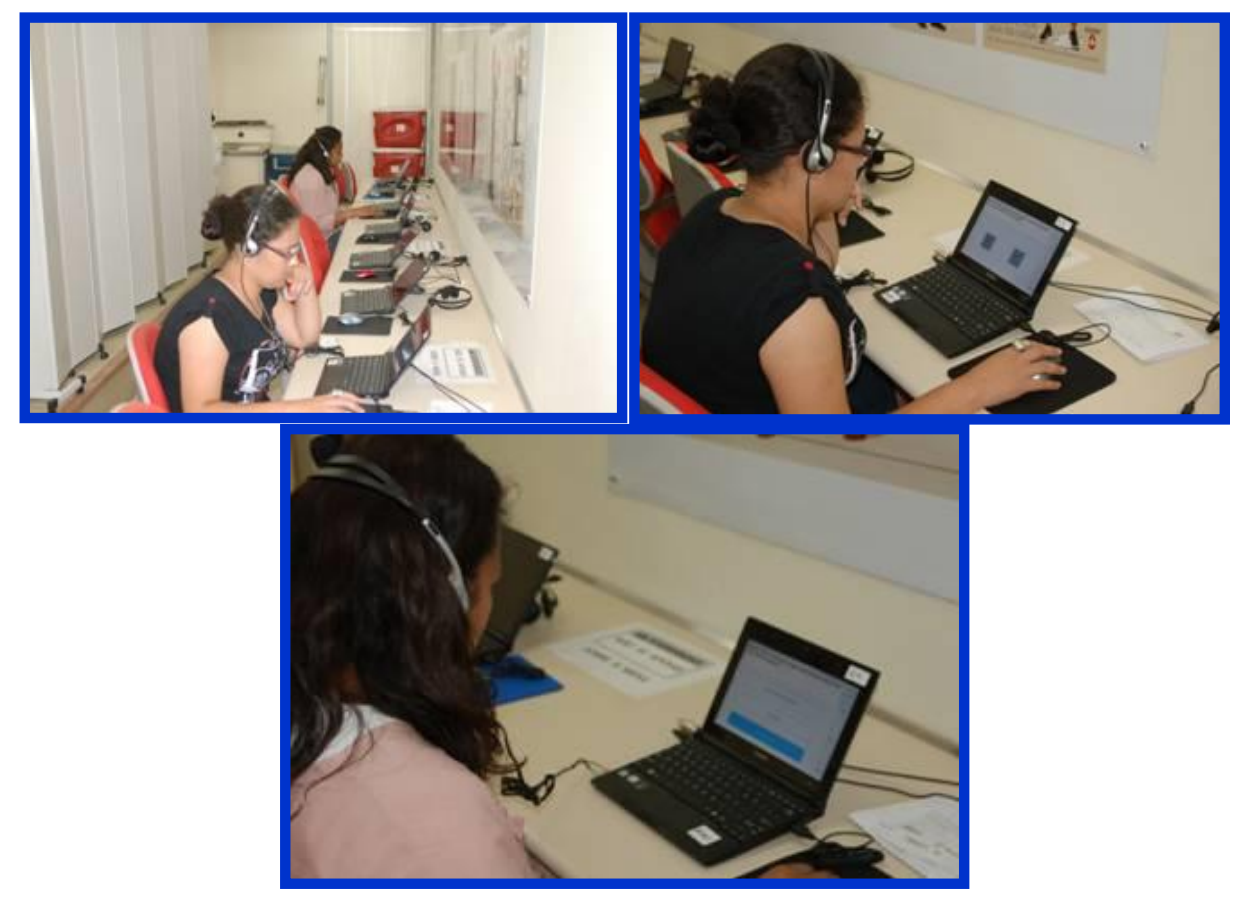

Entre abril de 2009 e março de 2011, realizamos um estudo caso-controle, multicêntrico, utilizando o ACASI, para entrevistar 341 doadores HIV positivos (EIA e Western blot) e um grupo controle de 791 doadores HIV negativos. O artigo original Risk factors for human immunodeficiency virus infection among Brazilian blood donors: a multicentre case-control study using audio computer-assisted structured interviews (31), publicado em 2013, avaliou fatores de risco para a infecção pelo HIV em doadores dos hemocentros de São Paulo, Belo Horizonte, Recife e Rio de Janeiro. Os fatores de risco foram baseados no questionário do Center for Diseases Control (CDC) dos EUA. As amostras reagentes nos EIAs e no Western blot foram também testadas através de um 
EIA menos sensível, denominado "EIA detuned", para identificar infecção recente ( $\leq 6$ meses) ou de longo tempo (>6 meses).

O ACASI conseguiu detectar fatores de risco em $77 \%$ dos casos e $13 \%$ dos controles, demonstrando superioridade quando comparado às entrevistas face-a-face. Os fatores de risco encontrados na população estudada foram relação sexual com portador do HIV (AOR=11,3; 95\%IC, 4,1-31,7) e uso de drogas injetáveis ou parceiro sexual de usuário de drogas injetáveis $(A O R=4,65 ; 95 \% \mid C, 1,8-11,7)$. Os fatores de risco identificados em homens e em mulheres, como esperado, foram diferentes. Para mulheres, os fatores de risco adicionais foram ter parceiro sexual HSH (AOR=13,5; 95\%IC, 3,1-59,8) e sexo desprotegido com múltiplos parceiros (AOR=5,19; 95\%IC: 2,112,9). O risco mais relevante entre homens foi $\mathrm{HSH}$ ( $\mathrm{AOR}=21,6 ; 95 \% \mathrm{IC}, 8,8-52,9$ ). Homens com orientação bissexual estavam associados com maior risco de infecção pelo HIV (AOR=7,18; 95\%IC, 2,3-22,2). Achados incomuns foram à associação entre ser HIV positivo e ter se exposto a procedimentos cirúrgicos (AOR=2,07; 95\%IC, 1,3-3,2), endoscopia (AOR=2,06; 95\%IC, 1,0-4,1) e contaminação ocupacional (AOR=3,18; 95\%IC, 1,7-6). Comportamentos associados à infecção recente pelo HIV foram HSH ou ser parceiro(a) de HSH (AOR=13,82; 95\%IC, 4,7-40,3) e usuário de drogas injetáveis (AOR=11,47; 95\%IC, 3-43,2).

Este estudo apresenta achados relevantes para a saúde pública e para orientar políticas governamentais, relevância esta que se expressa não somente em relação à segurança do sangue, mas também como um indicador atual dos fatores de risco para infecção pelo HIV nas grandes metrópoles brasileiras. O maior risco de ocorrer a transmissão transfusional do HIV é observado na doação realizada no período de 
janela imunológica do vírus. Doadores com infecção recente são mais suscetíveis a expor as unidades doadas a este risco. Os fatores de risco encontrados nessa população devem ser abordados de maneira prioritária pelos serviços de hemoterapia e demais serviços de saúde.

O critério de recusa de HSH nos últimos 12 meses é um ponto polêmico dentro das normas de triagem de doadores. Em 2015, nos EUA, a Food and Drug Administration (FDA) revogou a recusa por tempo indeterminado de HSH após 1977. OS EUA, de maneira semelhante ao Brasil, Argentina, Austrália, Suécia, Hungria e Reino Unido (exceto a Irlanda do Norte) (19), passaram a recusar candidatos que referem contato sexual com parceiro do mesmo sexo nos últimos 12 meses. As normas do Ministério da Saúde do Brasil estabelecem critérios mínimos para doação de sangue, mas não proíbem que cada serviço adote parâmetros mais restritos nos critérios de elegibilidade caso necessário. O Hemocentro do Rio de Janeiro recusa, por tempo indeterminado, candidatos que referem qualquer contato sexual atual ou passado com parceiro do mesmo sexo. Nos demais centros participantes deste estudo, a recusa ocorre se o candidato referir contato sexual com parceiro do mesmo sexo nos últimos 12 meses. Vale a pena ressaltar que, quando avaliamos contato com parceiro do mesmo sexo e infecção pelo HIV, as razões de chance encontradas em todos os hemocentros participantes foram muito semelhantes, sugerindo que o critério adotado pelo Hemocentro do Rio de Janeiro não é mais eficiente do que o praticado pelos demais. Particularmente, considero que a aderência do candidato à doação às normas dos hemocentros é mais importante para manter indivíduos de risco longe da doação do que a adoção de medidas restritivas. Com o estreitamento da janela 
imunológica do HIV a partir de testes cada vez mais sensíveis, acredito que a triagem clínica de doadores será mais focada no comportamento individual de cada candidato do que nos dados epidemiológicos populacionais.

Achados incomuns como a associação do HIV com endoscopia e procedimentos cirúrgicos nos últimos 12 meses devem ser melhor estudados. A infecção pelo HIV pode ter sido a causa que levou a estes procedimentos. Portadores do HIV são mais propensos a procurar serviços de saúde para receber cuidados médicos devido a sua soropositividade. O denominado "efeito-causa" é comum de ocorrer em estudos casocontrole e transversais, diferentemente dos estudos de coorte.

A associação de orientação bissexual com o HIV também merece ser avaliada de maneira mais detalhada. Homens bissexuais são mais propensos a transmitir o HIV para suas parceiras e, como detectamos, a atividade sexual do parceiro continua sendo um fator de risco importante em mulheres.

Por fim, a identificação precisa de doadores de risco e seu encaminhamento para CTAs parece ser mais importante do que estabelecer políticas cada vez mais restritivas para reduzir o risco residual da transmissão do HIV por transfusão. Conforme observamos, muitos doadores, incluindo controles, não estão revelando seus fatores de risco por ocasião da triagem clínica. Nos resultados acima apresentados, identificamos, por meio do ACASI, $13 \%$ de fatores de risco entre os controles. Este achado será objeto do próximo estudo a ser apresentado.

Em 2013, publicamos o manuscrito Undisclosed human immunodeficiency virus risk factors identified through a computer-based questionnaire program among blood 
donors in Brazil (32). Avaliamos os fatores de risco para HIV na população estendida de controles do estudo acima apresentado. No total, 901 doadores HIV negativos foram entrevistados utilizando-se o ACASI. Estes doadores haviam negado fatores de risco por ocasião da triagem clínica face-a-face.

Os principais fatores de risco identificados foram contato sexual recente com parceiro desconhecido ou ocasional (49 doadores), contato sexual com indivíduo exposto a sangue/fluidos corporais (26 doadores), múltiplos parceiros sexuais (19 doadores) e HSH (10 doadores). A idade maior do que 40 anos foi fator protetivo quando comparado com idade entre $18-25$ anos ( $A O R=0,45 ; 95 \% I C, 0,23-0,88$ ) para infecção pelo HIV, enquanto doadores de Recife versus de Belo Horizonte apresentava maior risco $(A O R=2,51 ; 95 \% I C, 1,42-4,44)$. Um em cada oito doadores apresentou fator de risco para HIV não revelado no momento da triagem clínica. Este achado é consistente com outros estudos que demonstram que o ACASI aumenta a chance de identificar comportamentos ou exposição a riscos em doadores de sangue, principalmente quando são abordadas questões mais estigmatizantes (33-35). A chance de obter uma resposta mais precisa é maior quando o doador não precisa revelar estes riscos na entrevista face-a-face, especialmente em doadores mais jovens.

Concluímos desse modo, que estudos utilizando o ACASI na entrevista pré-doação são necessários em nosso meio. A efetividade do ACASI utilizado de forma exclusiva, comparada à do ACASI combinado com a entrevista face-a-face necessita deve ser objeto de pesquisas. 
A compreensão dos doadores e suas atitudes em relação aos fatores de risco precisam ser conhecidas para que possamos propor mudanças nos processos da captação e da triagem de doadores e, ao mesmo tempo, reduzir cada vez mais o risco de transmissão do HIV por transfusão. Em 2014, publicamos o estudo multicêntrico Knowledge of HIV testing and attitudes towards blood donation at three blood centres in Brazil (36). Como complemento do estudo sobre motivação, realizamos uma pesquisa com 7.635 candidatos à doação para avaliar o grau de conhecimento destes sobre HIV e doação de sangue. O protocolo foi desenvolvido entre outubro e novembro de 2009, nos hemocentros de São Paulo, Belo Horizonte e Recife. As seguintes perguntas foram aplicadas:

- Para avaliar conhecimento dos processos dos hemocentros: (1) Você acha que o banco de sangue faz o teste para HIV melhor do que outros lugares?

- Para avaliar atitudes sobre doação: (2) Você acha que é OK doar sangue para se testar para o HIV?; (3) Você acha que é OK doar sangue, mesmo se tiver corrido algum risco para pegar HIV/aids, pois o banco de sangue vai fazer este teste de qualquer jeito e desprezar o sangue infectado?;

- Para avaliar conhecimento sobre janela imunológica (4) Se o seu este para HIV é negativo, você acha que é OK doar sangue mesmo tendo corrido algum risco de pegar HIV?; (5) O teste para HIV identifica todos os infectados?

- Para verificar se candidatos têm conhecimentos sobre a existência de CTAs ou outro local para se testar: (6) O banco de sangue é o único lugar que conheço que oferece testes gratuitos? 
As respostas para as primeiras cinco questões eram "Sim", "Não" e "Não sei", para última variava em escala de "concordo plenamente" a "discordo plenamente".

Cerca de $60 \%$ dos participantes responderam que o banco de sangue tem testes melhores que outros lugares e $42 \%$ dos entrevistados não estavam cientes da janela imunológica para HIV. Metade respondeu que não via problema doar sangue para ser testado para HIV, mas $67 \%$ dos participantes afirmaram ser inaceitável alguém doar se houvesse corrido risco de se infectar pelo HIV, mesmo se o sangue doado fosse testado. A análise multivariada mostrou que participantes com menor nível educacional, do Hemocentro de Recife e de reposição revelaram com mais frequência comportamento potencialmente associado a buscador-de-teste.

Nossos resultados demonstram que o conhecimento dos doadores em relação à transmissão do HIV por transfusão, processos dos hemocentros e testes de triagem é baixo na população das metrópoles pesquisadas. Uma porcentagem relevante dos candidatos acredita que é apropriado doar para ser testado para o HIV. A expansão da rede de CTAs e uma campanha de marketing nacional, direcionada especialmente a indivíduos com menor nível educacional, esclarecendo aos potenciais buscadores-detestes onde podem ser testados com eficiência e rapidez, se faz necessária. Por fim, como anteriormente mencionado, os hemocentros devem desenvolver canais eficazes de comunicação com os doadores para esclarecer dúvidas e orientá-los adequadamente. Vídeos para serem apresentados antes da doação parecem uma boa alternativa aos folhetos explicativos. 


\section{3b. Hepatites virais}

Os estudos sobre incidência e prevalência das hepatites $B$ e $C$ no Brasil mostram resultados diversos, variando conforme a região pesquisada em nosso território de $8.500 .000 \mathrm{~km}^{2}$. Há relatos de baixa prevalência da hepatite B no Sul do Brasil, taxas intermediárias no Nordeste e Sudeste e alta prevalência na região amazônica(37, 38). Estima-se que 1,5\% da população brasileira seja portadora do HCV. Prevalências mais altas do HCV são reportadas no Sul e Sudeste do nosso país, enquanto no Norte a prevalência é considerada baixa $(39,40)$.

Em doadores de sangue, o conhecimento da prevalência e incidência das hepatites virais é útil para estabelecer medidas de diagnóstico, aconselhamento e encaminhamento dos doadores infectados, assim como de prevenção em seus contactantes e na comunidade como um todo. Ainda, de acordo com a incidência ou prevalência destes patógenos, políticas para triagem clínica e sorológica de doadores devem ser regionalizadas.

A metodologia para diagnóstico das hepatites virais em estudos de prevalência e incidência é muito variável. Diversos estudos utilizam apenas testes de triagem que superestimam as taxas de infecção devido à ocorrência de resultados falso-positivos. Entre janeiro e dezembro de 2007, estudamos a prevalência do HBV e do HCV em doadores de sangue dos hemocentros de São Paulo, Belo Horizonte e Recife (41). Além disso, estimamos a incidência e o risco residual do HCV na nossa população. Nesta ocasião, a triagem para HCV e HBV era realizada apenas por métodos sorológicos. Casos confirmados para o HBV foram definidos como reatividade em duplicata no 
HBsAg e no anti-HBc, e para HCV como teste de EIA de terceira geração repetidamente reativo e imunoblot também reativo. A prevalência foi calculada em doadores de primeira vez. A incidência em doadores de repetição, por seu turno, foi estimada considerando resultados no período estudado e no histórico destes doadores, conforme previamente publicado (28). O risco residual para HCV foi calculado multiplicando-se a incidência (100.000 doações) pela janela imunológica (dias) sobre 365 dias, estimando a janela imunológica para testes de anticorpos para HCV de 58,3 dias.

Em 2007, foram realizadas 307.354 doações. A prevalência de HBV foi de 289 por 100.000 doações e a prevalência de HCV foi de 191 por 100.000 doações. Encontramos uma associação entre soropositividade para os marcadores de HBV e acentuadamente HCV e maior idade, o chamado efeito-idade-período-coorte. A incidência de HCV foi de 3,11 (95IC, 0,77-7,03) por 100.000 pessoas-ano e o risco residual do HCV de 1 para cada 200.000 unidades transfundidas, semelhante ao encontrada na Espanha (42). Estimamos que, se o NAT-HCV fosse utilizado na triagem de doadores, o risco residual da infecção pelo HCV cairia para 1: 1.585 .000 doações. O risco residual com o NAT-HCV seria o mesmo encontrado nos EUA antes da implantação do NAT naquele país (43).

A prevalência de HBV foi baixa em comparação aos dados de literatura. A maior sensibilidade e, especialmente, maior especificidade dos testes sorológicos, melhora das condições socioeconômicas do país, vacinação contra hepatite B em recémnascidos, doadores de sangue e populações de risco podem explicar esta diferença. A prevalência e incidência do HCV, da mesma maneira, vêm decrescendo devido ao controle da transmissão do HCV por transfusões e procedimentos médico-dentários. A 
maior prevalência de HCV entre doadores mais velhos reflete o risco a que estes foram expostos no passado, principalmente por meio da contaminação por transfusões, que se expandiram nas décadas de 40 e 50, e do uso de drogas intravenosas nas décadas de 70 e 80. Observamos maior prevalência do HCV em São Paulo do que nas outras capitais.

O reconhecimento de São Paulo como centro médico de referência desde a década de 1940 e o uso irrestrito do Gluconergan, uma droga não ilícita, de uso intravenoso, utilizada como estimulante nos anos $70(44,45)$, podem explicar este achado. As estimativas do risco residual por transfusão para o HCV e do HIV (28) foram úteis para determinar priorizar a implantação do NAT-HCV e HIV no nosso meio. Parece que a infecção pelo HCV em doadores de sangue, diferentemente do HIV, trata-se de um problema mais ligado à prevalência do que à incidência.

No passado, a triagem sorológica de doadores de sangue para hepatite B incluía apenas o HBsAg. Em 1993, a Portaria no 1.376 do Ministério da Saúde (46) tornou obrigatória a introdução do anti-HBc total na triagem sorológica. Em 2016, a Portaria no 158 acrescentou o NAT-HBV(4). Por ocasião da introdução do anti-HBc e também da alaninotransferase (ALT) na triagem de doadores, houve uma polêmica nacional, pois em algumas regiões do Brasil, como a Norte, a prevalência de anti-HBc reagente em doadores era superior a $80 \%$, o que levaria a um grande descarte de unidades e desabastecimento dos hemocentros. Devido à adição do anti-HBc na triagem sorológica, uma parcela dos doadores foi reconhecidamente identificada como portadora do HBV (HBsAg e anti-HBc reagentes). Outros apresentavam somente o antiHBC reagente e, em alguns centros, passaram a ser investigados. 
Na Fundação Pró-Sangue, realizamos rotineiramente o anti-HBs em doadores anti-HBc reagente e HBsAg não reagente. Caso o anti-HBs seja não reagente, o doador é considerado anti-HBc isolado. $\mathrm{O}$ anti-HBc isolado pode estar associado a (i) estado de portador crônico do HBsAg não-detectado; (ii) infecção remota por HBV com queda dos títulos de anti-HBs; (iii) transferência passiva de anticorpos anti-HBc em receptores de hemocomponentes não triados pelo anti-HBc; (iv) o período no qual o anti-HBs desaparece e o anti-HBc ainda não formou, chamado de janela imunológica da hepatite B e (v) resultado falso-positivo. Entre 1994 e 1997, testamos um algoritmo para investigar o significado do anti-HBc isolado em 124 doadores de sangue (47). Trata-se de um estudo de coorte, no qual todos participantes foram avaliados clinicamente, os fatores de risco para HBV foram pesquisados e os testes sorológicos foram refeitos. Naqueles doadores que persistiam com o perfil sorológico com anti$\mathrm{HBC}$ alterado, realizamos a aplicação de uma dose de vacina sintética contra HBV e, em 30 dias, o anti-HBs foi retestado. Naqueles doadores que não produziam o anti-HBs, realizamos a pesquisa do DNA do VHB através da reação em cadeia da polimerase (PCR).

Ao final do protocolo, identificamos que $15,2 \%$ dos participantes eram imunes. 0 antiHBs não havia sido detectado anteriormente devido a variações neste anticorpo. Resultado falso-positivo para o anti-HBc foi detectado em $16 \%$ dos participantes. $\mathrm{Na}$ comparação entre falsos e verdadeiros anti-HBc positivos, o índice do CO/S mostrou significância estatística $(p<0,001)$. Quando este índice é menor do que dois, a possibilidade de resultado falso-positivo é de $83,3 \%$. Cerca de $34 \%$ dos participantes 
apresentaram reação anamnéstica à vacina do HBV e $34,8 \%$ foram submetidos à pesquisa do DNA do HBV. Todos apresentaram PCR negativo (Figura 9).

O algoritmo testado foi capaz de definir o significado do anti-HBc isolado na grande maioria dos doadores. A menor sensibilidade do teste de PCR para pesquisa do DNA do HBV em comparação com os testes atualmente disponíveis foi uma limitação que encontramos. Contudo, tanto na prática clínica quanto na rotina de atendimento aos doadores em hemocentros, os achados deste estudo são úteis para esclarecer o significado do anti-HBc alterado.

No manuscrito Clinical significance of elevated alanine aminotransferase in blood donors: a follow up study (48), realizamos o seguimento (coorte) de doadores de sangue com a ALT alterada, avaliamos os fatores associados com a elevação desta enzima hepática e identificamos as causas de ALT persistentemente elevada. Anteriormente, a ALT era utilizada como marcador indireto da infecção pela hepatite não-A-não-B. Com a descoberta que o HCV era o agente da maior parte das hepatites não-A-não-B e do uso de testes para detectar anticorpos contra o HCV, a realização da ALT na triagem de doadores foi descontinuada. 
Figura 9. Distribuição dos pacientes em diferentes grupos ao final do protocolo

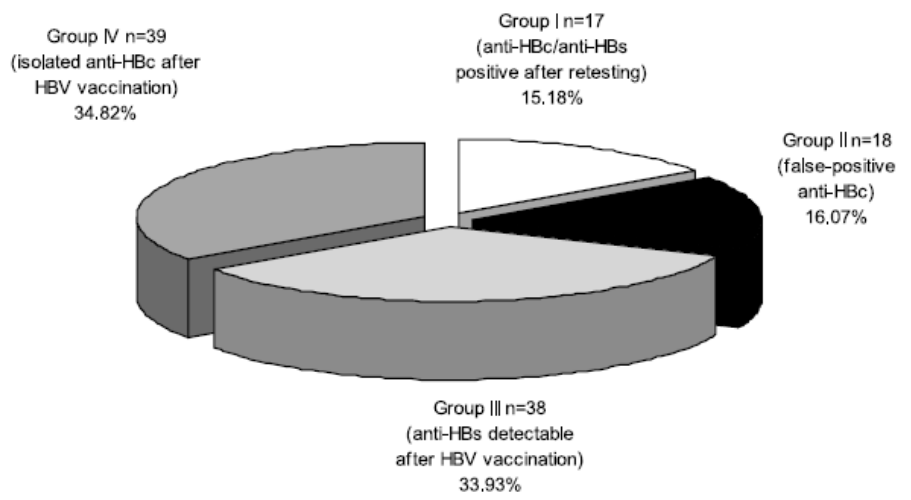

Investigamos 119 doadores com aumento persistente da ALT e sorologias para HBV e HCV negativas. Durante o seguimento, observamos que os níveis de ALT, em geral, caíram durante o seguimento. Obesidade $(30,2 \%)$ e alcoolismos $(28,6 \%)$ foram as principais causas associadas à elevação da ALT em doadores de sangue. Em 9,2\% dos casos, não conseguimos identificar uma etiologia para o aumento da ALT. O diagnóstico histológico, realizado via a biópsia hepática, foi obtido em 40 pacientes, sendo que $35 \%$ apresentavam esteatose hepática, $30 \%$ esteato-hepatite, $12,5 \%$ hepatites não específicas, $15 \%$ histologia normal. Cirrose alcoólica, hemocromatose e fibrose portal não específica foram detectados em três casos.

Concluímos que a maior parte dos doadores com ALT alterada apresentam alterações hepáticas leves. Não obstante quadros mais graves de doença hepática também foram diagnosticados. Estes achados chamam atenção para as condições de saúde de parte da nossa população de doadores que, mesmo aprovados na triagem clínica, por vezes estão com sua saúde debilitada. Embora a função básica de um hemocentro não seja promover ações de saúde pública, o grande número de candidatos à doação 
submetidos à triagem hematológica, clínica e sorológica nos oferece a oportunidade de agir na melhoria das condições de saúde da nossa população.

Com o crescente conhecimento sobre o HCV nas últimas décadas, publicamos entre 2014 e 2015 dois artigos originais sobre Qualidade de Vida Saúde em portadores do HCV: um estudo sobre genótipos, mutações, resistência a drogas e fatores de risco para HCV em doadores de sangue e uma análise filogenética do HCV na cidade de São Paulo.

$\mathrm{O}$ artigo HCV genotypes, characterization of mutations confering drug resistence to protease inihbitors, and risk factors among blood donors in São Paulo (49) apresenta um estudo transversal dos subtipos do HCV, das variações que levam à resistência aos inibidores de protease e da associação dos diferentes genótipos, subtipos e resistência do HCV, aos fatores de risco para esta infecção, em doadores de sangue.

Foram incluídos 202 doadores que retornaram para notificação e aconselhamento e apresentavam anti-HCV (EIA) e imunoblot reagentes. Todos os doadores com alterações sorológicas são rotineiramente submetidos a um questionário sobre fatores de risco para doenças transmissíveis pelo sangue. O genótipo e as mutações que levam à resistência aos inibidores de protease foram determinados pelo sequenciamento direto das regiões NS5b e NS3 respectivamente. A carga viral foi determinada por um PCR “in-house" para a região 5'-NCR.

Os subtipos 1b, 1a e 3 a foram encontrados em $45,5 \%, 32 \%$ e $18 \%$ dos doadores, respectivamente. A carga viral média do genótipo 1 foi significantemente maior do que do genótipo 3. O genótipo 1 foi mais encontrado em doadores jovens e o 3 em 
doadores mais velhos $(0,047)$. Ambos são reconhecidamente associados ao uso de drogas intravenosas. As variantes resistentes aos inibidores de proteases foram detectadas em $12,8 \%$ das amostras com genótipo 1 . Um único fator de risco para HCV (exposição parenteral) foi reportado por $19,1 \%$ dos doadores, ao passo que $32 \%$ apresentavam dois fatores e quase $30 \%$ apresentavam múltiplos fatores de risco. Em20\% dos casos, não encontramos causas para a infecção pelo HCV.

Estes dados sugerem que os fatores de risco para a infecção pelo HCV ainda não são completamente identificados em nosso meio. Nossos resultados mostraram uma taxa intermediária de resistência a drogas nos doadores quando comparados com outros estudos (50-52). Não houve correlação entre genótipo, variantes de resistência e fatores de risco para HCV. Entretanto, a vigilância constante dos doadores de sangue infectados garante não somente um melhor entendimento das vias de propagação do HCV na nossa população, mas também permitem entender a prevalência de variantes resistentes que levam a implicações terapêuticas nestes indivíduos.

Os diferentes subtipos do HCV são originários da África e Ásia e foram disseminados mundialmente durante a Segunda Guerra Mundial. Naquela ocasião houve um incremento exponencial de eficientes maneiras de transmissão do HCV por transfusões de sangue contaminado, procedimentos médico-odontológicos e uso de drogas intravenosas. A entrada dos diferentes subtipos do HCV nas diferentes regiões do nosso planeta ocorreu em períodos distintos. A taxa de expansão de cada subtipo é também variável. 
No estudo Phylogenetic analysis of the emerge of main hepatites $C$ vírus subtypes in São Paulo, Brazil (53), estimamos o crescimento e a expansão dos subtipos mais prevalentes do HCV circulando no estado de São Paulo. Utilizamos 465 sequencias 5b não-estrutural do HCV, provenientes de dois diferentes estudos, sendo um com pacientes e o outro com doadores, portadores do HCV. A amostra corresponde ao período de 14 anos. O Tempo para o Ancestral Comum Mais Recente (TMRCA) para os três genótipos do HCV foi investigado usando a abordagem do Bayesian Markov Chain Monte Carlo (MCMC), implementado no Bayesian Evolutionary Analysis by Sampling Tree (BEAST).

A análise de evolução demonstrou que os diferentes subtipos do HCV apresentam distintos padrões de crescimento. A introdução dos subtipos 1a e 3a ocorreu, respectivamente, por volta de 1979 e 1967. O HCV-1a mostrou a maior taxa de crescimento $(r=0,4)$ quando comparado aos demais e teve maior curva de crescimento em meados dos anos 90, persistindo até 2005. Considerando que o controle da transmissão do HCV por transfusão de sangue iniciou-se em 1993, acreditamos que a principal via de transmissão do subtipo 1a tenha sido o uso drogas injetáveis. 0 subtipo 3a apresentou maior taxa de crescimento até $1990(r=0,32)$. Sabe-se que este subtipo começou a se expandir mundialmente após a metade do século XX devido ao compartilhamento de agulhas. Alguns estudos associam o genótipo 3 ao uso de estimulantes intravenosos nos anos 70, como o Gluconergan. A associação com estes grupos pode explicar a maior prevalência deste genótipo em indivíduos mais velhos.

O subtipo 1b do HCV parece ter entrado há mais tempo em São Paulo, por volta de 1932, possuindo diferentes linhagens ainda circulando (G1 a $G 4$ ). Houve um 
crescimento exponencial de crescimento deste subtipo $(r=0,26)$ entre 1980 e metade da década de 90 . O crescimento do subtipo 1 b coincide com eventos históricos como a fundação do primeiro banco de sangue e a implementação de serviços transfusionais, assim como a expansão de procedimentos médicos como a hemodiálise, por exemplo. De maneira oposta, as medidas para prevenção da transmissão da hepatite B (anti-HBc e ALT) e HIV no final dos anos 90 e a triagem obrigatória das unidades de hemocomponentes para o HCV em 1993 coincidem com o declínio da deste subtipo. O começo do declínio da expansão do subtipo 1b no final dos anos 1980 em São Paulo corrobora a eficácia das medidas que foram tomadas de maneira indireta para prevenir a transmissão da chamada hepatite não-A-não-B. Considerando que o HIV e o HCV possuem vias de transmissão em comum, o próprio controle da transmissão do HIV realizada nos bancos de sangue paulistas contribuiu indiretamente para o declínio da transmissão do HCV 1 b.

A Figura 9 apresenta a representação filogenética dos subtipos 1a, 1b e 3a do HCV e a dinâmica de expansão dos diferentes subtipos.

Concluímos que após um período de expansão inicial os três subtipos mais comuns do HCV começaram a declinar no estado de São Paulo graças ao controle da transmissão parenteral do HCV. Atualmente, com o controle da transmissão do HCV pela transfusão de sangue, os usuários de drogas injetáveis se tornaram os reservatórios naturais deste vírus. Esforços para identificar estes portadores do HCV e encaminhálos para receber atenção e tratamento adequado são prioritários para erradicar o HCV do nosso meio. 
Figura 9. (A) HCV-1a e (B) HCV-3a árvores MCMC mostrando a clássica filogenia em forma de estrela. (C) HCV-1b árvore MCMM mostrando quatro grupos bem delimitados (G1 a G4). (D) Plotagem da dinâmica de expansão na população dos diferentes subtipos.

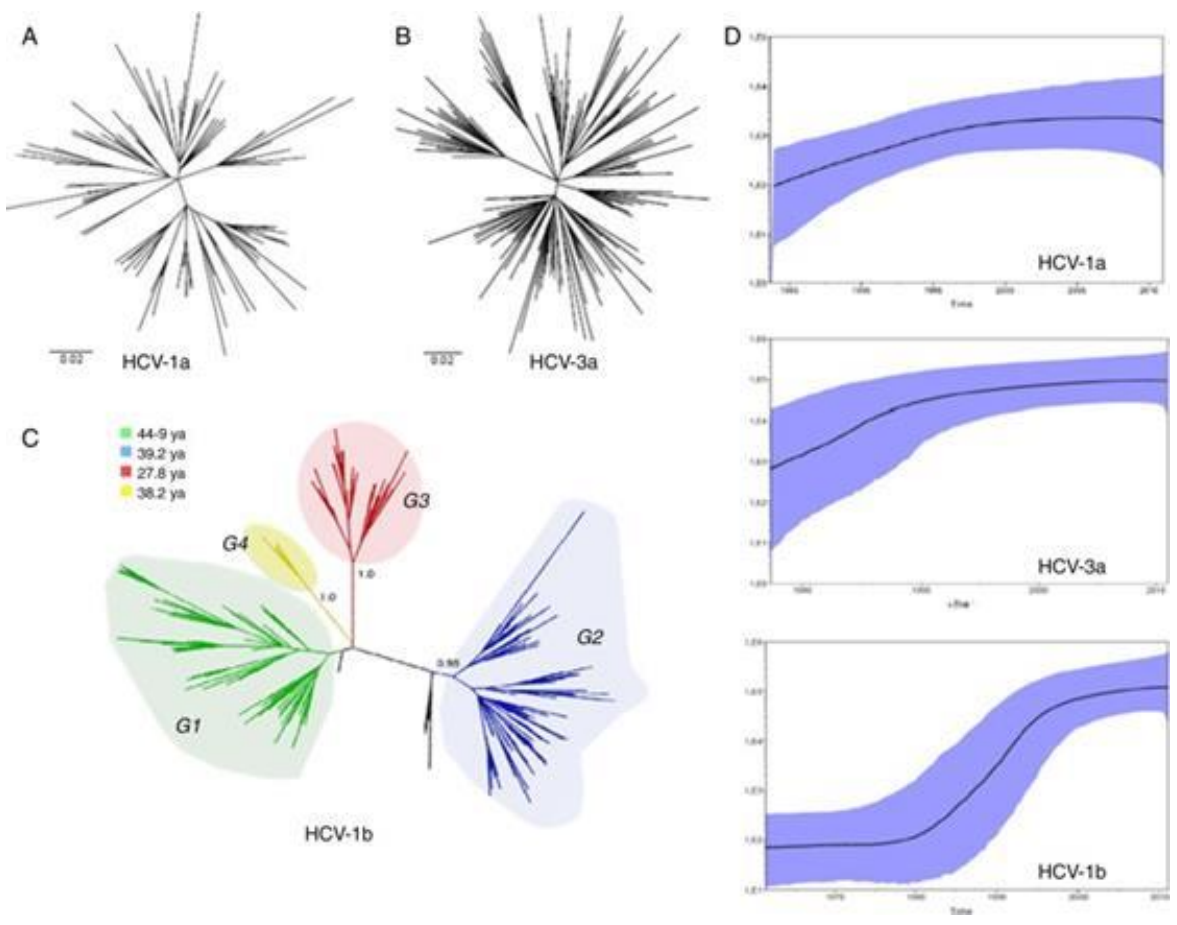

Existem evidências de que pacientes portadores das hepatites B e C apresentam pior qualidade de vida. Especula-se também que os portadores destas hepatites podem ter uma pior qualidade de vida devido à simples presença do HBV ou do HCV $(54,55)$. Não se sabe como as infecções crônicas pelo HBV e HCV atuam na qualidade de vida de doadores de sangue, que, a princípio, acreditam ser saudáveis. Desconhece-se também qual é o impacto da notificação da infecção pelo HBV ou HCV na qualidade de vida destes doadores.

Para responder a estas questões, entre fevereiro de 2007 e julho de 2009, realizamos um estudo de coorte prospectivo em doadores de sangue com diagnóstico confirmado de hepatite B e hepatite C. Os doadores tiveram a QVRS avaliada por meio dos 
questionários Medical Outcome Study-36 Item Short Form Health Survey (SF-36) e Liver Disease Quality of Life (LDQOL-1.0). Ambos os instrumentos são validados em português. O SF-36 é um instrumento genérico para avaliar a QVRS em diferentes doenças e populações. Já o LDQOL-1.0 é específico para doenças hepáticas. O SF-36 foi aplicado em três etapas do processo de notificação: (1) quando o doador comparecia ao ambulatório de doadores para repetição de exames a desconhecia seu status sorológico; (2) após ser notificado sobre seu status sorológico e (3) após 30-60 dias, quando comparecia a um centro de referência pública para investigação clínica e terapêutica. O LDQOL-1.0 foi aplicado após a notificação do doador.

Formamos quatro grupos para avaliar a QVRS, portadores do HBV, portadores do HCV, grupo de falsos-positivos e grupo controle negativo. O grupo controle foi pareado por sexo, idade e comorbidades com os grupos de portadores do HCV e HBV. Os resultados serão apresentados nos dois estudos a seguir.

Para avaliar a QVRS em 32 portadores do HBV e 35 do HCV, comparamos as respostas no SF-36, antes e depois de os doadores saberem seu status sorológico, com 67 controles negativos. O LDQOL-1.0 foi administrado após a notificação dos doadores portadores do HCV e HBV. Os resultados foram publicados no manuscrito Altered quality of life in the early stages of chronic hepatitis $C$ is due to the virus itself (56).

Demonstramos que os portadores do HCV apresentam pior QVRS mesmo antes de saber que são portadores deste vírus. Foram detectadas alterações estatisticamente significantes em sete de oito domínios e nos componentes físico e mental do SF-36 destes indivíduos. Já os portadores do HBV apresentavam alterações apenas em dois 
dos oito domínios avaliados e no componente físico. Após a notificação, as mesmas alterações permaneceram nos portadores do HCV e dois outros domínios se mostram comprometidos nos infectados pelo HBV. Estes achados corroboram a hipótese de que portadores do HCV, diferentemente dos do HBV, já apresentam pior QVRS devido apenas à presença do HCV.

No estudo Health-related quality of life among blood donors with hepatitis $B$ and hepatitis C: longitudinal study before and after diagnosis (57), avaliamos o impacto da notificação do status sorológico de 32 doadores portadores do HBV e 35 do HCV na QVRS destes, comparando-os com 38 doadores que apresentaram resultados falsopositivos. Os doadores com resultados falso-positivos foram submetidos ao mesmo processo de notificação.

A QVRS foi relativamente similar em doadores com HBV, $\mathrm{HCV}$ e com resultados falsopositivos antes da notificação. Todos estavam envolvidos no mesmo processo e submetidos ao estresse de ser portador de uma doença transmissível. Entretanto, após a notificação, a QVRS foi estatisticamente inferior em seis e oito domínios nos doadores com HBV e HCV. Três domínios e os componentes físico e mental em doadores com HCV apresentaram melhora quando medidos antes da notificação e quando estes compareciam para investigação clínica e terapêutica.

Concluímos que houve uma piora da QVRS em doadores que foram notificados como portadores do HBV e do HCV. Nos doadores com HCV, a possibilidade de atenção médica e terapêutica curativa pode ser responsável por uma melhora da QVRS. 
O processo de notificação e aconselhamento de doadores afeta a QVRS tanto em portadores do HBV e do HCV quanto em pessoas saudáveis. Melhor comunicação e transparência quanto ao motivo pelo qual o doador está sendo convocado para repetir exames podem mitigar o estresse associado a este processo. Diferentes abordagens de convocação dos doadores com sorologias alteradas necessitam ser testadas. Estudos avaliando a QVRS em portadores de outras doenças transmissíveis devem trazer mais subsídios para aprimorar a abordagem dos doadores com sorologias alteradas.

\section{3c. Sífilis}

A sífilis, mesmo sendo uma doença muito antiga, ainda é um problema mundial de saúde pública. A Organização Mundial de Saúde estima que anualmente haja 12 milhões de novos casos de sífilis, sendo que $90 \%$ destes ocorrem em países em desenvolvimento (58). No Brasil, estima-se que um milhão de novos casos ocorram ao ano (59). O contato sexual é a principal via de transmissão do Treponema pallidum ( $T$. pallidum), agente da sífilis. O risco da transmissão da sífilis por transfusão de sangue é mínimo, fato este atribuível à seleção de doadores, triagem sorológica e transfusão de hemocomponentes refrigerados. O último relato de transmissão da sífilis num país desenvolvido ocorreu na Holanda em 1977 (60). Porém, em centros nos quais não há triagem do sangue doado para sífilis, a transmissão da sífilis por transfusão ainda ocorre (61). Além disso, a transmissão da sífilis por hemocomponentes não refrigerados, como as plaquetas, por exemplo, e o relaxamento de critérios de triagem podem expor receptores de transfusões ao risco desta infecção. 
Mesmo em países desenvolvidos, há relatos durante surtos de sífilis de que o DNA do T. pallidum é detectável em indivíduos não tratados e pode infectar parceiros destes indivíduos (62). Entre doadores de sangue, foi visto que indivíduos infectados podem manter o DNA do T. pallidum circulante por até três semanas após a infecção (63).

Muito tem sido discutido em relação à sífilis e à transfusão sanguínea. Alguns especialistas da área advogam, inclusive, que a triagem sorológica para sífilis das unidades de sangue doadas deve ser descontinuada nos países desenvolvidos. Contudo, pouco se conhece sobre o perfil do doador que apresenta Testes Sorológicos para Sífilis (STS) alterados.

Entre 2009 e 2014, publicamos dois artigos originais que buscavam conhecer mais sobre o perfil de doadores de sangue com STS alterados e um que avaliava a presença do DNA do T. pallidum em dois grupos diferentes de doadores com STS alterados. Dados demográficos, fatores de risco para a sífilis, motivação para doação e presença do DNA do T.pallidum são aspectos abordados nestes manuscritos.

$\mathrm{O}$ artigo original Profile of blood donors with serologic tests reactive for the presence of syphilis in São Paulo, Brazil (59) tem como objetivo determinar características demográficas e fatores de risco em doadores com sífilis recente e passada e suas implicações para a triagem clínica e sorológica destes doadores. Realizamos um estudo transversal nos quais doadores com perfil sorológico de sífilis recente foram comparados quanto aos dados demográficos, fatores de risco para sífilis e demais sorologias alteradas com doadores com perfil sorológico de sífilis no passado. Neste estudo, a definição de sífilis recente foi títulos de VDRL maior ou igual para 1/16, FTA- 
ABS e EIA para sífilis reagentes. Sífilis no passado foi definida como VDRL não reagente, FTA-ABS e EIA para sífilis reagentes (cicatriz sorológica). Todos os participantes foram submetidos a entrevista face-a-face por ocasião da notificação de seus resultados sorológicos.

Do total de 2.439 entrevistas revistas, $2.161(88,6 \%)$ de doadores com perfil de sífilis no passado e $278(11,4 \%)$ com sífilis recente. Fatores associados com infecção recente foram (i) idade $\leq 20$ anos (OR=36,5; 95\%IC, 15,8-84,1), (ii) duas doações prévias (OR=2,7; 95\%IC, 1.9-3.9), (iii) HSH (OR=8,2; 95\%IC 3,2-20,8), (iv) orientação bissexual (OR=11,4; 95\%IC, 3,6-36,3), (v) dois ou mais parceiros sexuais nos últimos 12 meses $(\mathrm{OR}=2,3 ; 95 \% \mathrm{IC}, 1,3-4,0)$, (vi) relato de sintomas para sífilis $(\mathrm{OR}=4,5 ; 95 \% \mathrm{IC}, 2,8-7,1)$ e (vii) soropositividade para HIV (OR=39,6; 95\%IC, 4,6-339,8). Doadores altruístas, comparados com doadores de reposição, também foram associados com infecção recente $(\mathrm{OR}=1,5 ; 95 \% \mathrm{IC} 1,2-1,9)$.

A maior prevalência de sífilis em doadores mais velhos é algo esperado devido ao maior tempo de exposição destes indivíduos ao T. pallidum ao longo da vida. Do mesmo modo, indivíduos mais velhos foram mais expostos em décadas passadas, quando a sífilis era endêmica no nosso país. HSH foi fator de risco encontrado em $6 \%$ dos doadores com sífilis recente e em $0,6 \%$ dos com sífilis passada. Um aumento nas infecções por sífilis desde meados dos anos 1990 tem sido observado em determinadas populações, especialmente em HSH. Embora o número de casos de soropositividade para o HIV tenha sido pequeno em nossa série $(1,8 \%$ na sífilis recente e 0,05\% na passada), a prevalência do HIV em doadores com sífilis recente foi 40 vezes maior do que em doadores com sífilis passada e, ao mesmo tempo, 50 vezes maior do 
que na população em geral. Tanto o T. pallidum quanto o HIV são sexualmente transmissíveis e comportamento de alto risco facilita a coinfecção. Nossos dados corroboram a ineficácia do uso de STS como marcador indireto para HIV em bancos de sangue.

Um achado curioso foi a associação de sífilis recente com duas doações de sangue. Uma explicação lógica para este achado é que doadores com sífilis passada, os quais mantiveram a cicatriz sorológica, são informados que não podem voltar a doar quando da notificação. Por outro lado, indivíduos com sífilis recente podem ter doado no passado, quando eram soronegativos nos STS, e depois voltaram a doar.

Diferentemente do senso comum, encontramos associação entre infecção recente e doadores altruístas. Uma possível explicação para este achado é que parte dos doadores que se dizem altruístas podem, na verdade, ser buscadores-de-testes. Uma implicação prática para diminuir o risco da doação de sangue por buscadores-de-teste é fidelizar doadores de reposição qualificados no pool de doadores de repetição.

É importante enfatizar o papel dos hemocentros na notificação e no aconselhamento destes doadores. Por um lado, indivíduos portadores de sífilis são encaminhados para receber tratamento adequado. Por outro, indivíduos tratados diminuem a chance de infectar seus parceiros, quebrando o ciclo de disseminação do T. pallidum. A possibilidade de um doador com sífilis mudar o seu comportamento de alto risco após notificação, orientação, encaminhando e tratamento efetivamente existe. Entretanto, observamos que uma pequena parcela de doadores com sífilis passada mantém 
comportamento de alto risco. Estudos para avaliar se o diagnóstico e o tratamento da sífilis podem mudar o comportamento destes indivíduos são necessários.

A contínua vigilância do comportamento de doadores com infecção recente ou passada para sífilis é importante para aumentar a segurança transfusional não somente em relação à sífilis, mas também em relação ao HIV. Em 2014, publicamos o manuscrito Demographic, risk factors and motivations among blood donors with reactive serologic tests for syphilis in São Paulo, Brazil (64). Este estudo expandiu ainda mais o conhecimento que adquirimos com o estudo anterior.

Realizamos um estudo caso-controle, entrevistando 75 doadores de sangue com VDRL $>1 / 8$, EIA e FTA-ABS reagentes, 80 doadores com VDRL não-reagente, EIA e FTA-ABS reagentes e um grupo controle de 34 doadores com testes sorológicos de triagem nãoreagentes. No momento da notificação, os doadores responderam a um questionário detalhado sobre fatores de risco para sífilis, histórico de uso de álcool e drogas ilícitas e motivação para doar.

Em relação aos controles, doadores com $\operatorname{VDRL}>1 / 8$ eram divorciados $(\mathrm{OR}=12,53$; 95\%IC 1,30-120-81), relataram mais de seis parceiros sexuais nos últimos 12 meses (OR=7,1; 95\%IC, 1,12-44,62) e refeririam relação sexual com parceiro do mesmo sexo, no caso, homens, nos últimos 12 meses (OR=8,18; 95\%IC, 1,78-37,70)Doadores com VDRL não-reagente apresentaram como fator protetivo ser mulher (AOR=0,26; 95\%IC, $0,07-0,96)$, mas apresentaram como preditores de risco ser mais velho ( $A O R=10,2$; $95 \%$ IC, 2,45-42,58) e ter tido seis ou mais parceiros sexuais nos últimos 12 meses $(A O R=8,37 ; 95 \% I C, 1,49-46,91) . U m$ em cada três doadores com VDRL>1/8 e um em 
cada dez doadores com VDRL não-reagente acreditam que correram risco de se infectar com o HIV. Não encontramos diferença estatisticamente significante quanto ao uso de drogas entre doadores com VDRL>1/8 e VDRL não reagente.

Os dois grupos de doadores com STS alterados apresentaram probabilidade oito vezes maior de ter seis ou mais parceiros sexuais nos últimos 12 meses. De maneira semelhante ao estudo anterior, observamos que uma parcela de indivíduos com VDRL não-reagente e EIA e FTA-ABS reagentes, perfil característico de cicatriz sorológica ou sífilis latente, mantém comportamento sexual de alto risco. Ainda, HSH foi um dos principais preditores de apresentar $\operatorname{VDRL}>1 / 8$, o que corrobora nossos achados anteriores.

Não uso do preservativo nos últimos 12 meses foi relatado por $65,3 \%$ dos doadores com VDRL $>1 / 8$, por $53,8 \%$ dos com VDRL não-reagente e por $52,9 \%$ dos controles. Considerando que um terço dos doadores com STS alterados consideram-se em risco de adquirir o HIV, a baixa frequência de uso de preservativos nesta população expõe estes indivíduos ao risco de contrair infecções sexualmente transmissíveis e o HIV. A razão do não uso de preservativos numa população sabidamente de risco deve ser esclarecida.

Um terço dos doadores mencionou que doou para ajudar um amigo. $\mathrm{O}$ apelo direto foi a principal motivação encontrada nesta população. Altruísmo foi a motivação de $32 \%$ dos doadores com VDRL>1/8 e 21\% dos com VDRL não-reagente. Interesse próprio foi reportado por aproximadamente $25 \%$ dos doadores com STS alterados. 
Concluímos que, embora doadores expostos à sífilis relatem e reconheçam comportamento de risco, a maior parte destes doou sangue motivado pelo apelo direto. Os fatores de risco para a sífilis encontrados neste estudo corroboram nossos achados anteriores e conhecê-los é importante não somente para os bancos de sangue, mas também para a saúde pública em geral.

Apesar de reconhecermos que uma parcela de doadores com STS alterados mantém comportamentos de alto risco para adquirir infecções sexualmente transmissíveis, persistia a dúvida quanto à possibilidade destes manterem o T. pallidum circulante. 0 manuscrito Prevalence of Treponema pallidum DNA among blood donors with two different serologic test profiles for syphilis in São Paulo (65) apresenta os resultados da pesquisa do DNA do T. pallidum em 197 amostras de doadores VDRL>1/8, EIA e FTAABS reagentes e 80 amostras de doadores com VDRL não reagente, EIA e FTA-ABS reagentes.

Desenvolvemos um teste de PCR em tempo real e detectamos DNA do T. pallidum em $1,02 \%$ das amostras de doadores VDRL $>1 / 8$. Nenhuma amostra dos doadores VDRL não-reagente apresentou positividade neste teste. Portanto, cerca de $1 \%$ dos doadores de sangue com teste de VDRL $>1 / 8$ e EIA e FTA-ABS mantém o DNA do T. pallidum circulante e são potencialmente infectantes. Em contrapartida, doadores com VDRL não-reagente provavelmente não transmitem a sífilis por transfusão.

Exames laboratoriais, por si sós, não são suficientes para diagnosticar o estágio da infecção pela sífilis, mas o perfil sorológico com VDRL>1/8, EIA e FTA-ABS reagentes, geralmente é correlacionado com a sífilis recente. Consequentemente, podemos 
afirmar que doadores com este perfil têm maior probabilidade de transmitir o $T$. pallidum por transfusão mesmo depois da formação de anticorpos.

O achado deste estudo nos permite garantir que a triagem sorológica para sífilis tem um papel importante na prevenção da sífilis transfusional. Isso se faz essencial especialmente nos países com alta prevalência de infecções sexualmente transmissíveis e nos quais doadores apresentam comportamento de alto risco para esta infecção.

\section{3d. Doença de Chagas}

A doença de Chagas é uma doença negligenciada, causada pelo protozoário Trypanosoma cruzi (T. cruzi). O antígeno é transmitido predominantemente pelo contato com as fezes dos triatomíneos, insetos vetores, conhecidos popularmente no Brasil como "barbeiro" ou "chupança". O protozoário também é transmissível pela via oral, pela ingestão de alimentos contaminados com os parasitas, ou, ainda de mãe para filho (transmissão vertical) e por transfusões de sangue e transplante de órgãos.

Atualmente, a doença de Chagas é endêmica em 21 países do continente americano. Estima-se que entre 6 e 7 milhões de pessoas estejam infectadas, embora mais de $90 \%$ delas desconheçam tal condição. Anualmente, ocorrem no mundo mais de 12 mil mortes associadas à doença, que, devido à globalização, também passou a ser uma preocupação na Europa e na Ásia, principalmente por conta de doações de sangue infectado com o T. cruzi de imigrantes de áreas endêmicas. No Brasil, estima-se que existam hoje mais de 1 milhão de pessoas infectadas pela Doença de Chagas, das quais 
$60 \%$ vivem em áreas urbanas, sendo muitos destes assintomáticos. Estima-se que, no Brasil, morram 6 mil anualmente pessoas devido às complicações crônicas da doença.

A maioria dos pacientes é assintomática ou oligossintomática na fase aguda da Doença de Chagas. A maior parte dos indivíduos não tratados evolui para a fase indeterminada da doença, na qual são quase sempre soropositivos, mas não possuem lesões em órgãos alvo. Devido a triagem universal das unidades de sangue doadas para Doença de Chagas nas áreas endêmicas e, recentemente, em áreas não-endêmicas, doadores soropositivos assintomáticos têm sido detectados. Os grandes desafios dos bancos de sangue são identificar e excluir portadores crônicos assintomáticos da Doença de Chagas, notificá-los e encaminhá-los para que recebam cuidados médicos. Os métodos atuais para identificação da infecção pelo $T$. cruzi são baseados na detecção de anticorpos contra o parasita. No Brasil, há uma variedade de testes comerciais disponíveis para uso. Atualmente, utilizamos um teste EIA para Doença de Chagas na triagem de doadores.

Em relação à Doença de Chagas, apresentarei dois estudos dos quais participei. 0 primeiro, publicado em 1996, avalia a correlação entre testes sorológicos e o perfil epidemiológico da Doença de Chagas em doadores soropositivos para T. cruzi. O segundo, publicado em 2013, estimamos a incidência anual da miocardiopatia chagásica em doadores de sangue assintomáticos soropositivos para o T. cruzi.

$\mathrm{O}$ artigo original Risk of exposure to Chagas'disease among seroreactive Brazilian donors (66) apresenta os resultados obtidos na triagem sorológica para a Doença de Chagas em 411.617 doações de sangue em São Paulo entre 1983 e 1994. Avaliamos 
também o seguimento de 1.267 doadores repetidamente reativos em pelo menos um dos testes de triagem (na ocasião, utilizávamos três testes). Os dados epidemiológicos de 321 indivíduos que permaneceram reativos durante o seguimento foram comparados com um grupo controle de 119 doadores soronegativos e 45 doadores com resultado falso-positivo para Doença de Chagas.

Entre os participantes repetidamente reativos em três testes de triagem, $94,6 \%$ permaneceram reativos durante o seguimento. Naqueles repetidamente reativos em apenas um teste de triagem, 70,8\% apresentaram resultado negativo nos três testes durante o seguimento. A maioria dos participantes que apresentaram dois ou três testes de triagem reagentes apresentavam fatores de risco para a infecção pelo $\mathrm{T}$. cruzi. Uma proporção significante $(29,1 \%)$ dos doadores reativos em apenas um teste de triagem apresentavam evidências de exposição ao vetor da Doença de Chagas quando comparado com $14,6 \%$ dos controles $(p=0.007)$. Doadores que apresentam os três testes sorológicos reativos certamente estão infectados pelo T. cruzi. Entretanto, acreditamos que uma parcela dos doadores reativos em apenas um teste para Doença de Chagas com epidemiologia positiva devem estar infectados. A proporção de participantes que responderam positivamente para as questões (1) Alguém na sua família tem a Doença de Chagas? e (2) Você já morou numa casa em que havia o "barbeiro"? aumentou de acordo com o número de testes reativos $(p<0.001)$.

A ausência de um teste com sensibilidade suficiente para excluir doadores soropositivos e assintomáticos para a Doença de Chagas naquela ocasião levou à inclusão de perguntas sobre exposição para Doença de Chagas na triagem de doadores de sangue, as persistem até os dias atuais. A legislação vigente estabelece, no artigo 
58, que "Para Doença de Chagas, o candidato com antecedente epidemiológico de contato domiciliar com Triatomíneo em área endêmica ou com diagnóstico clínico ou laboratorial de Doença de Chagas deve ser excluído de forma permanente, sendo considerado doador inapto definitivo" (4).

Nos últimos 30 anos, não há qualquer relato de transmissão de $T$. cruzi por transfusão. Houve uma melhora relevante nos testes de triagem para T. cruzi. Contudo, não sabemos se a exclusão de candidatos provenientes de áreas endêmicas de alguma maneira colaborou para o risco zero da transmissão do $T$. cruzi em nosso meio. Considerando os movimentos migratórios, inclusive de imigrantes provenientes de outros países sul-americanos para o Brasil, considero prudente manter esta restrição na triagem clínica de doadores de sangue.

Poucos estudos para estabelecer a incidência da miocardiopatia chagásica em portadores da forma indeterminada da doença têm sido publicados nos últimos anos. Estima-se que pacientes com a forma indeterminada da Doença de Chagas evoluem para as formas clínicas da doença (cardiomiopatia ou a doença gastrointestinal) de 10 a 20 anos após a infecção. Não obstante, preditores clínicos da evolução da Doença de Chagas para suas formas mais graves não são bem conhecidos. O CDC recomenda o tratamento da Doença de Chagas em todos portadores do T. cruzi com menos de 18 anos de idade e a possibilidade de tratamento daqueles com idade entre 19 e 50 anos. Grande parte dos cardiologistas brasileiros não trata a Doença de Chagas devido às incertezas em relação ao prognóstico da doença e à toxicidade dos medicamentos disponíveis. 
Realizamos o estudo de coorte retrospectivo Ten-year incidence of Chagas cardiomiopathy among asymptomatic Trypanosoma cruzi-seropositive former blood donors (67) para avaliar a incidência da miocardiopatia chagásica em doadores de sangue com Doença de Chagas na forma indeterminada. Como objetivo secundário, avaliamos os preditores de evolução da doença da forma indeterminada para a forma clínica cardíaca.

Recrutamos 255 doadores de sangue da cidade de São Paulo (SP) e 244 de Montes Claros (MG), os quais foram diagnosticados, por meio de exames sorológicos, com a Doença de Chagas entre 1996 e 2002. Como controle, recrutamos 239 doadores de São Paulo e 249 de Montes Claros que doaram no mesmo período e apresentavam sorologias negativas. Todos os participantes foram submetidos, entre 2008 e 2010, a um algoritmo que incluiu avaliação clínica, exame físico, exames laboratoriais, eletrocardiograma (ECG) e ecocardiograma (ECO). Três cardiologistas, especialistas em Doença de Chagas, receberam um sumário dos dados clínicos de cada participante, exames laboratoriais e resultado do ECG e ECO. O painel de especialistas foi "cego" em relação ao status sorológico dos participantes. Os achados clínicos e laboratoriais de cada participante foram utilizados para classificá-los como (i) portador de miocardiopatia chagásica, (ii) provável portador de miocardiopatia chagásica, (iii) possível portador de miocardiopatia chagásica e (iv) não-portador de miocardiopatia chagásica.

O tempo médio entre a doação e a avaliação do desfecho foi de 10,5 anos para os soropositivos e 11,1 anos para os soronegativos. Entre os 499 doadores soropositivos, 120 (24\%) eram portadores de miocardiopatia chagásica e, entre os 488 soronegativos, 
24 (5\%) apresentavam miocardiopatia. A incidência de miocardiopatia chagásica foi estimada em 1,85 por 100 pessoas-ano. Entre os 120 soropositivos classificados como tendo miocardiopatia Chagásica, apenas 31 (26\%) apresentavam fração de ejeção $<50 \%$ e apenas 11 (9\%) foram classificados como classe funcional II ou mais da New York Heart Association. Houve associação estatisticamente significante entre miocardiopatia chagásica e sexo masculino (OR=1,97; 95\%IC, 1,23-13,16), história de alteração prévia do ECG (OR=6,09\%; 95\%IC, 3,64-10,19) e presença de B3 na ausculta cardíaca $(\mathrm{OR}=6,01 ; 95 \% \mathrm{IC}, 3,00-12,05)$. Encontramos uma taxa de incidência moderada de miocardiopatia entre doadores diagnosticados há cerca de 10 anos com $T$. cruzi. Nosso algoritmo de triagem para diagnóstico da miocardiopatia chagásica, consistente em exame físico seguido de ECG, seguido de ECO naqueles com ECG alterado, foi bem sensível e específico.

Avaliamos a sensibilidade e especificidade deste algoritmo em pacientes sabidamente portadores de miocardiopatia chagásica e detectamos 99 de 101 casos (sensibilidade de $98 \%$ ). Os fatores prognósticos identificados, quais sejam sexo masculino, história prévia de ECG alterado e presença de B3 ao exame físico, podem ser úteis para decidir quais portadores do $T$. cruzi têm maior risco de miocardiopatia e são potencialmente elegíveis para tratamento.

Em termos de patogênese sobre a Doença de Chagas, apresentamos um estudo bem controlado para avaliar a incidência de miocardiopatia chagásica em indivíduos soropositivos previamente assintomáticos. Os estudos prévios de incidência de miocardiopatia chagásica em indivíduos assintomáticos haviam se baseado em séries 
de casos encaminhados aos serviços de referência. Portanto, a incidência que estimamos representa melhor a de indivíduos soropositivos em geral.

A inclusão de controles negativos nos permitiu validar o algorítmico proposto e estimar a presença de miocardiopatia por outras causas. Nos países Latino Americanos, nos quais a Doença de Chagas é endêmica, mas também vêm ocorrendo o aumento da incidência de miocardiopatia por outras causas, como a aterosclerótica, nosso algoritmo pode ser útil.

Por fim, nossos dados são de interesse de cardiologistas em países endêmicos e não endêmicos que recebem imigrantes latino-americanos, pois trazem subsídios para melhor estimar o prognóstico e considerar a terapêutica nos pacientes portadores da Doença de Chagas. 


\section{Uso racional do sangue e hemocomponentes e outras pesquisas com doadores e receptores de sangue}

\section{3a. Uso racional do sangue e hemocomponentes}

A transfusão de concentrado de hemácias, plasma e plaquetas, quando corretamente indicada, é essencial para a saúde dos pacientes com diversas condições clínicas. Não há substitutos do sangue que apresentam a mesma eficácia dos hemocomponentes que atualmente dispomos. Por outro lado, os recursos para coleta, processamento, triagem sorológica e imunematológicas, provas de compatibilidade e transfusão são restritos. A doação de sangue, como mencionado anteriormente, é sazonal e pode haver períodos de baixa no estoque. Em 2015, representantes do Grupo Cooperativo Iberoamericano de Medicina Transfusional (GCIAMT), especialistas da Organização Panamericana da Saúde (OPAS), da Universidade de São Paulo e do Hemocentro de São Paulo, se reuniram na cidade de São Paulo e elaboraram um protocolo para avaliar o uso do sangue e componentes na América Latina (AL) (68). 
O protocolo foi desenvolvido em duas etapas. Na primeira as requisições de transfusão são avaliadas. Numa segunda etapa, os prontuários médicos são avaliados. 0 protocolo possibilita ao seu usuário realizar uma análise descritiva de como são as solicitações de sangue em cada serviço transfusional, como as unidades são liberadas, quais pacientes serão transfundidos, quais os benefícios da transfusão, quantas unidades foram transfundidas e quantas foram desprezadas.

Propomos utilizar o protocolo em centros responsáveis por $80 \%$ das transfusões numa determinada jurisdição. Em cada centro 1.000 questionários devem ser preenchidos por monitores previamente treinados. Os questionários foram desenvolvidos em Sistemas Modulares de Pesquisa, baseados na internet (Vide Figuras 10-12), em português e inglês. A versão em espanhol está em desenvolvimento. Todos os centros serão auditados quanto à qualidade dos dados e cada centro poderá utilizar os seus próprios dados. Os dados coletados pelos diversos centros serão utilizados pelo CGCIAMT e pela OPAS para avaliar o uso do sangue e componentes na América Latina. Este projeto é bem desafiador e com a implementação das propostas discutidas, pode trazer benefícios para diversos países, localidades e regiões da AL. Nosso intuito é desenvolver um estudo piloto em Medellín, Colômbia e em Recife, após as devidas autorizações dos Comitês de Ética locais e a disponibilidade de recursos financeiros. 


\section{Figura 10. Exemplo da página de login do usuário}

\section{SMS Use of Blood in Latin America}

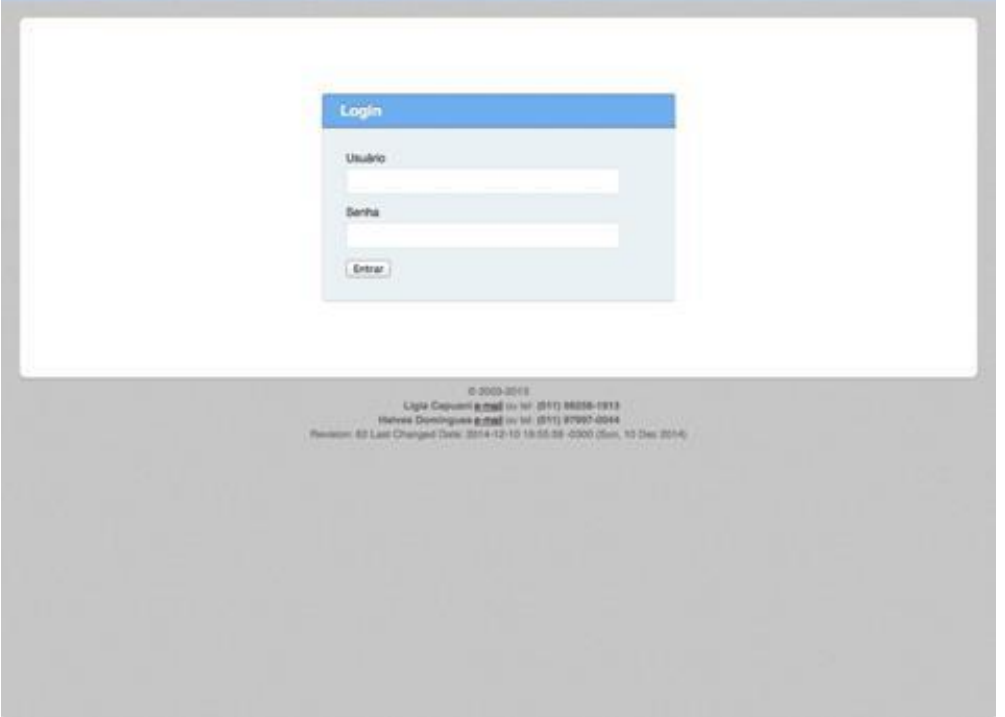

Figura 11. Exemplo da lista de receptores de hemocomponentes

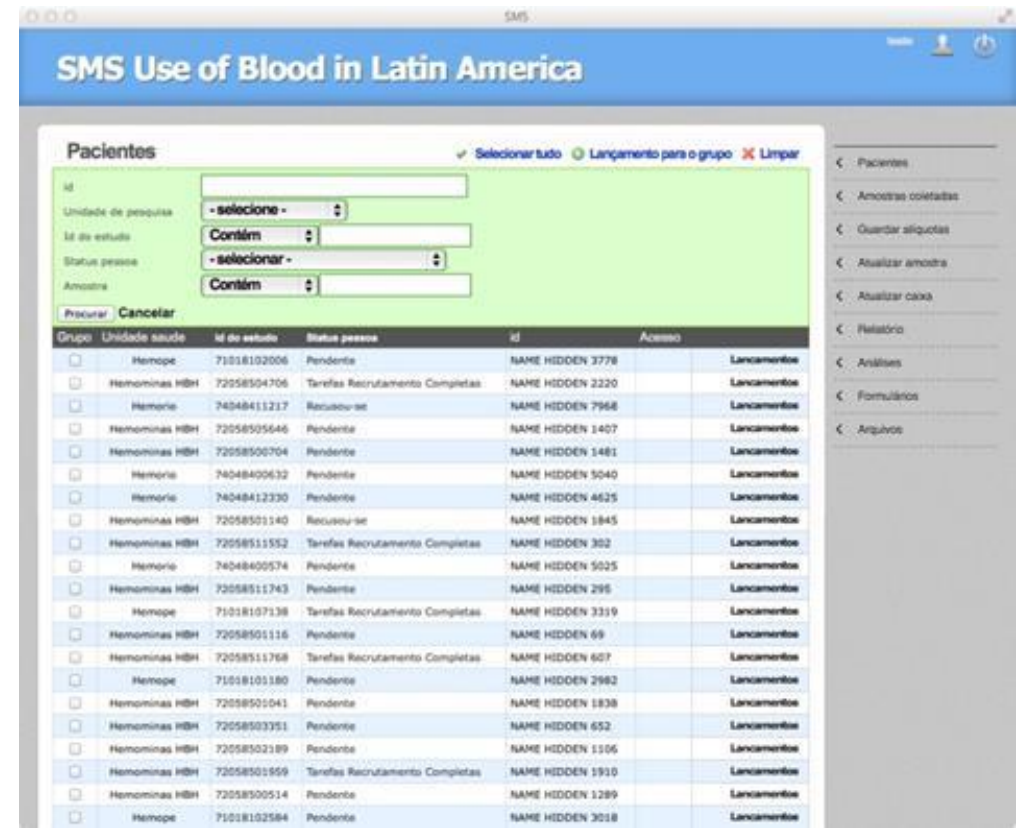


Figura 12. Exemplo dos relatórios possíveis do uso de sangue e hemocomponentes

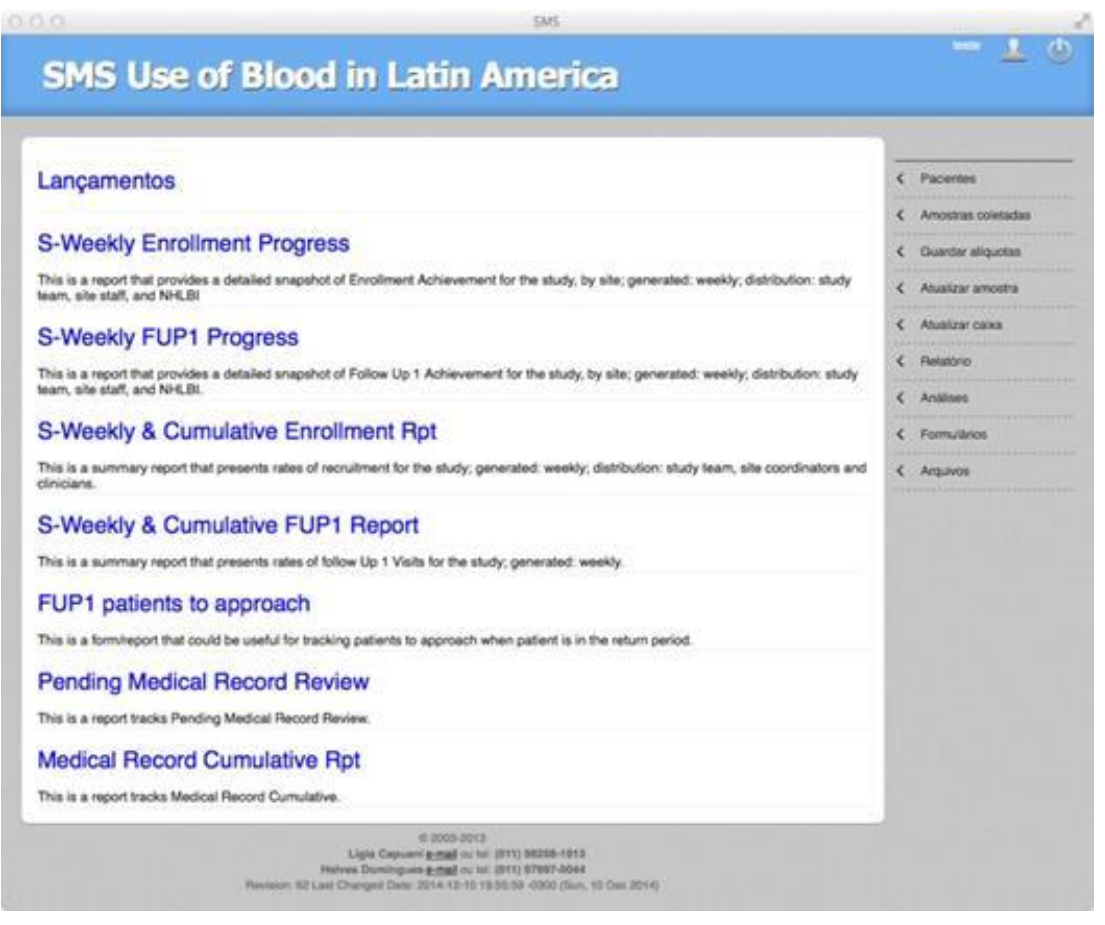

3b. Eficácia da plataforma OpenArray na identificação de alterações genéticas relacionadas a trombose e hemocromatose hereditária em doadores de sangue

Uma situação bem comum dentro da rotina da hemoterapia é a participação voluntária de doadores de sangue em pesquisas de diversas áreas da medicina. Doadores de sangue são colaborativos, têm sentimentos altruístas e doam sangue para ajudar alguém que precisa. Dificilmente eles se negam a doar suas amostras para pesquisas. Para os pesquisadores doadores de sangue são uma amostra conveniente, estão facilmente à disposição, existe rastreabilidade e podem ser utilizados como controles negativos representando a população saudável. Vale a pena ressaltar que o intuito básico de um hemocentro é colher e distribuir sangue e componentes. 
No manuscrito Evaluation of high throughput method for the detection of mutations associated with thrombosis and hereditary hemochromatosis in Brazilian donors (69) apresentamos um estudo transversal comparando a plataforma do OpenArray com o sistema em tempo real do PCR-FRET (Fluorescence resonance energy transfer) para identificar alterações genéticas associadas à trombose (G1691A e G20210A), hiperhomocisteínemia (C677T e A1298C), e hemocromatose hereditária (C282Y, H63D e S65C) em amostras de 400 doadores de sangue do Hemocentro de São Paulo.

O fator $V$ de Leiden é a principal causa genética de trombose e é encontrado em $5 \%$ dos caucasianos. O risco relativo de trombose é 3-10 vezes maior em heterozigotos e 50-100 vezes em homozigotos. A segunda causa genética mais frequente de trombose é a mutação da protrombina (FII). A prevalência desta alteração em caucasianos é de aproximadamente 1-4\% e a frequência desta mutação entre pacientes com trombose venosa é 5 a 7\%. A hiper-homocisteinemia também leva a eventos pró-trombóticos e está relacionada à presença das mutações C677T e A1298C. Tanto em homizogotos quanto em heterozigotos acarreta aumento dos episódios hemorrágicos e de acidentes vasculares cerebrais.

A hemocromatose hereditária, por outro lado, é uma desordem do metabolismo do ferro caracterizada pelo aumento dos depósitos de ferro no fígado, coração, pele, glândulas endócrinas e articulações. As mutações mais frequentemente encontradas são C282Y, H63D e S65C.

Observamos $100 \%$ de concordância em todos os ensaios testados, exceto para a HFE C282Y, que mostrou $99,75 \%$ de concordância. O gene C282Y da hemocromatose foi 
posteriormente confirmado pelo sequenciamento mostrando que a plataforma OPenArray é precisa. As frequências de cada alteração genética identificada foram para o Fator V de Leiden G1691A 98,8\% (G/G), 1,2\% (G/A); mutação do gene da prótrombina G2021A 99,5\% (G/G), 0,5\% (G/A); genes da hiper-homocisteínemia C677T 45,5\% (C/C), 44,8\% (C/T), 9,8\% (T/T); A1298C 60,3\% (A/A), 33,6\% (A/C), 6,1 (C/C), e da hemocromatose C282Y 96\% (G/G), 4\% (G/A), H63D 78,1\% (C/C), 20,3\% (C/G), 1,6\% (G/G) E S65C 98,1 (A/A), 1,9 (A/T).

Algumas frequências acima descrtitas estão associadas a alterações genéticas que podem levar à trombose e refletem as prevalências de mutações dos genes encontrados na população de doadores da cidade de São Paulo. Evidentemente, esta amostra necessita ser ampliada, e deve haver seleção de amostras nas demais regiões brasileiras, para ser representativa da nossa população. O diagnóstico precoce de alterações genéticas em doadores merece atenção. Por um lado, pode ser vantajoso, pois possibilita tratamento e prevenção, como no caso das doações de sangue, ou sangria terapêuticas, que previnem dos danos da hemocromotase hereditária. Por outro lado, pode trazer mais preocupação para indivíduos que nunca irão apresentar manifestações clínicas daquele distúrbio. O Fator $V$ de Leiden, por exemplo, não é recomendado pelas atuais diretrizes como método de triagem populacional em mulheres, exceto quando há histórico familiar de tromboembolismo (70).

A plataforma OpenArray mostrou alta concordância com o método padrão do PCRFRET em tempo real. A possibilidade de oferecer testes genéticos para doadores de sangue precisa ser avaliada através de estudos que pesem os riscos e benefícios desta estratégia. 


\section{3c. Prevenção da Lesão Pulmonar Aguda Relacionada à Transfusao (TRALI)}

A Lesão Pulmonar Aguda Relacionada à Transfusao (TRALI) se caracteriza por desconforto respiratório agudo que ocorre durante a transfusão, ou até seis horas após sua realização, sem evidência de lesão pulmonar, acompanhado de hipoxemia com saturação de oxigênio $<90 \%$ em ar ambiente ou PaO2/FiO2 $<300$ mmHg e exame de imagem de tórax apresentando infiltrado pulmonar bilateral sem evidência de sobrecarga circulatória.

A ocorrência da TRALI leva a morte em $5-25 \%$ dos casos. Ainda, a TRALI é a principal causa de morte relacionada à transfusão nos EUA (71). Há duas hipóteses para explicar a etiologia da TRALI. A primeira é a ativação do processo inflamatório no endotélio pulmonar devido à interação entre antígenos pulmonares do receptor e anticorpos anti-HLA e anti-HNA circulantes no sangue de doadores sensibilizados. O segundo mecanismo para a TRALI consiste na liberação de citocinas durante a estocagem. As citocinas armazenadas são capazes de ativar a resposta inflamatória em receptores previamente predispostos.

A formação de anticorpos anti-HLA e anti-HNA pode ocorrer nas mulheres, durante a gestação, ou em receptores de transfusões sanguíneas. Produtos plasmáticos carregam o maior risco de TRALI nos receptores. No Reino Unido a estratégia de liberação de produtos plasmáticos de doadores do sexo masculino foi efetiva para reduzir a TRALI (72).

No estudo transversal The impact of policies to restrict the use of plasma containing products and apheresis platelets from female donors to mitigate transfusion related 
acute lung injury (TRALI) in Brazil (73) avaliamos o impacto de três diferentes políticas para mitigar a incidência de TRALI no nosso meio: (1) fornecer somente produtos plasmáticos provenientes de doadores homens, (2) recusar candidatas mulheres para doar plaquetas por aférese e (3) recusar mulheres com três ou mais gestações (multíparas) para doar plaquetas por aférese.

Avaliamos 544.814 doações de sangue realizadas nos hemocentros de São Paulo, Recife e Belo Horizonte, entre abril de 2008 e dezembro de 2009. Caso a primeira estratégia fosse adotada, produtos plasmáticos apenas de homens, haveria 0 decréscimo de $30,8 \%$ das unidades de plasma e $24,1 \%$ das doações de plaquetas por aférese. No caso de adotar a segunda estratégia, ou seja, recusar mulheres como doadoras de plaquetas, haveria a perda de $24,1 \%$ dos produtos coletados por aférese. A terceira estratégia, recusa de multíparas, acarretaria numa perda de $5 \%$ das doações de plaquetas por aférese.

A recusa de mulheres multíparas como doadoras de plaquetas por aférese traz menos impacto na disponibilidade de hemocomponentes do que as demais políticas examinadas. Portanto, no contexto atual de grande demanda de hemocompontes, parece ser a estratégia mais adequada para prevenir a TRALI sem levar ao desabastecimento dos hemocentros. A triagem de candidatas à doação de plaquetas por aférese para anticorpos anti-HLA e anti-HNA é desejável, entretanto os custos envolvidos neste processo superam os recursos disponíveis dos hemocentros públicos.

Na Fundação Pró-Sangue, 37,1\% das nossas coletas de plaquetas por aféreses eram provenientes de mulheres. Destas doadoras, 20,7\% referiam três ou mais gestações, 
$15 \%$ duas, $16,4 \%$ uma e $52,4 \%$ eram nuligestas. Baseados nos resultados deste estudo, introduzimos a recusa gradual de mulheres, de acordo com o número de gestações, a fim de prevenir a ocorrência de TRALI. No primeiro ano de implantação desta política, limitamos a doação de plaquetas por aféreses para mulheres que tiveram até duas gestações, no segundo ano, uma gestação, e desde abril de 2016, somente nuligestas são aceitas como doadoras de plaquetas por aférese. Nesse meio tempo, captamos mais doadores homens para prevenir o desabastecimento de concentrados de plaquetas por aférese.

O conhecimento das características de nossos doadores nos possibilitou a adequação de uma política de prevenção da TRALI sem levar a desabastecimento dos nossos estoques, demonstrando a utilidade práticas deste estudo, nas rotinas dos hemocentros.

\section{3d. Recrutamento de doadores com sorologias alteradas}

A cada ano 108 milhões de pessoas doam sangue no mundo (74). Alguns destes doadores apresentam resultados alterados nos testes sorológicos de triagem, dependendo da prevalência de cada doença transmissível por transfusão em cada região do globo. A notificação de doadores com sorologias alteradas é essencial para esclarecer o status sorológico dos doadores, encaminhá-los para receber cuidados médicos, prevenir sequelas de doenças parasitárias, bacteriana, e virais e prevenir a contaminação de seus contactantes. Ainda, doadores com resultados falso-positivos podem ser reintegrados ao pool de doadores saudáveis. Entretanto, baixas taxas de 
retorno de doadores convocados para aconselhamento e notificação têm sido descritas (75).

$\mathrm{O}$ artigo original inédito $A$ randomized trial to evaluate the use of text messaging, letter and telephone call reminders to improve return of blood donors with reactive serologic tests (76) apresenta um estudo randomizado para avaliar a eficácia da convocação de doadores com resultados sorológicos alterados, utilizando-se um meio de comunicação eletrônico, o SMS (Short Message Service), telefonema e carta.

Uma amostra consecutiva de doadores de primeira vez, com telefone celular registrado com prefixo da grande São Paulo, e que não responderam a duas tentativas de convocação padrão por carta, foram aleatoriamente selecionados para receber um SMS, telefonema ou carta. Todos os métodos continham o mesmo roteiro. Ao final do protocolo comparamos as taxas de retorno em 30 dias para cada um dos métodos aplicados.

Entre agosto de 2013 e julho de 2014 houve 122.635 doações de sangue e 2,5\% dos doadores apresentaram testes de triagem sorológica alterada. Doadores de primeira vez representaram $37,1 \%(45.485)$ do total e $3,1 \%$ (1.405) apresentaram testes sorológicos alterados. Após a primeira convocação 54,7\% retornaram para notificação e aconselhamento e após a segunda 10,8\%. Os 484 que não retornaram foram randomizados para receber SMS, carta ou telefonema.

A convocação por telefone foi mais eficientes do que pelo SMS $(39,8 \%$ versus $28,4 \%$; $\mathrm{OR}=1,66 ; 95 \% \mathrm{IC}, 1,05-2,64)$, mas não mais eficiente do que a carta $(39,8 \%$ versus 34,4\%; OR=1,26; 95\%IC, 0,8-1,99). Comparando SMS e carta não encontramos 
diferenças nas taxas de retorno (28,4\% versus 34,4\%; OR-1,32; 95\%IC, 0,83-2,12). Doadores mais jovens apresentaram menor taxa de retorno. Para cada ano a mais na idade a chance de retorno aumentou em $2 \%$ (OR=1,02; 95\%IC, 1,01-1,04) (Figura 13). Entretanto quando comparamos a idade com os diferentes tipos de convocação, não encontramos diferenças nas taxas de retorno (Figura 14).

Figura 13. Distribuição da idade de acordo com as taxas de retorno em doadores com testes sorológicos alterados.

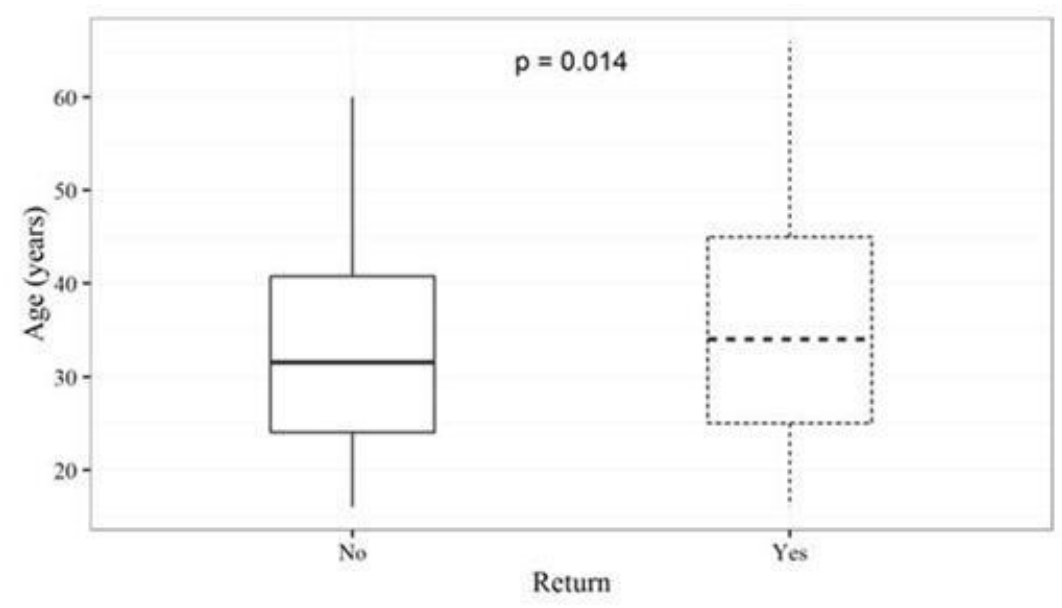

Figura 14. Distribuição da idade e taxas de retorno entre os diferentes tipos de convocação em doadores com sorologias alteradas.

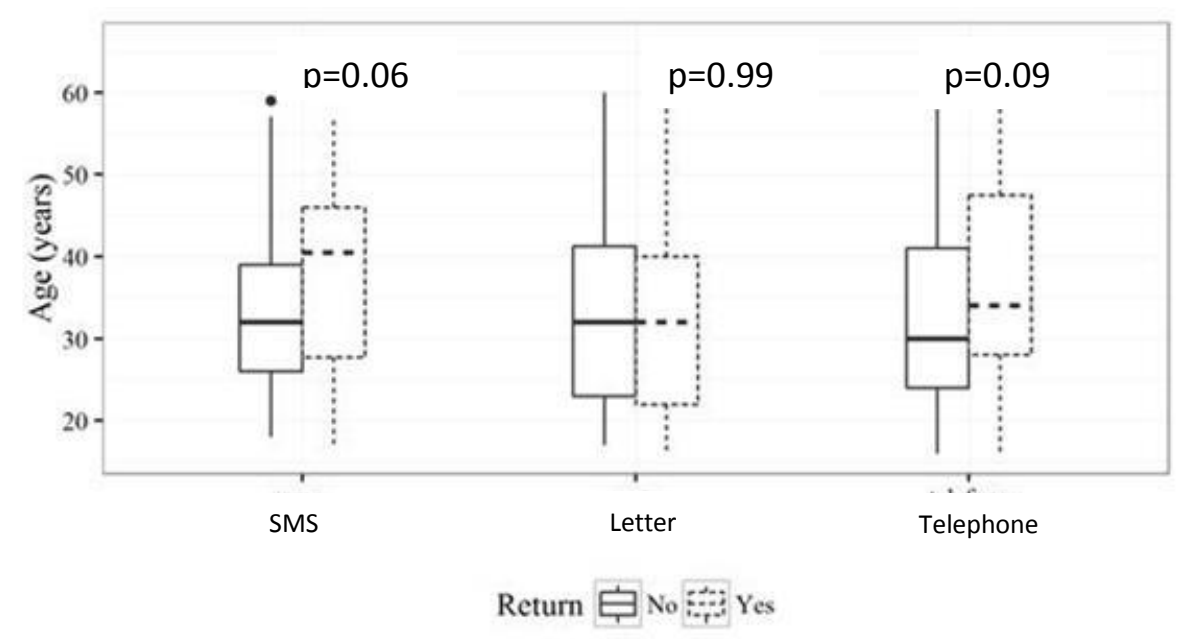


O desenho deste estudo nos possibilitou testar a eficácia de diferentes tipos de convocações em doadores com sorologias alteradas que foram refratários à convocação padrão. Selecionamos doadores de primeira vez, pois doadores de repetição conhecem melhor o serviço e tendem a ser mais responsivos às convocações. O contato telefônico permite uma interação pessoal que explica a melhor taxa de retorno quando comparado ao SMS e carta. Além disso, através do telefonema temos certeza que a mensagem foi recebida pelo doador.

Este é o primeiro estudo randomizado que será publicado para avaliar as taxas de retorno por diferentes tipos de convocação em doadores com testes sorológicos alterados. A estratégia utilizada pode ser aplicada para responder outras perguntas em bancos de sangue, por exemplo, qual a melhor intervenção para prevenir reações adversas em doadores e qual a dose adequada de concentrados de plaquetas para prevenir hemorragias em pacientes plaquetopênicos graves.

Embora atrativo o SMS não aumenta o retorno de doadores ao hemocentro para notificação. O reconhecimento que o contato telefônico é superior ao SMS pode ser extrapolado para as demais áreas da medicina (ex. acompanhamento de doentes crônicos, pacientes em uso de anticoagulantes, etc.) com a finalidade de estreitar a comunicação entre serviços de saúde e pacientes. 


\section{CONCLUSÕES}

As principais conclusões dos 32 estudos compilados neste texto sistematizado são que:

1. Existem flutuações no número de doações nos principais hemocentros brasileiros ao longo do ano e podemos prever a chance de desabastecimento nos hemocentros durante cada período do ano. Campanhas de recrutamento de doadores, realizadas por meio de mensagens de texto, cartas ou telefonemas, são necessárias para prevenir a falta de hemocomponentes em cada um dos feriados com baixo número de doações.

2. Estratégias para incentivar doadores a retornar mais brevemente aos hemocentros e doarem mais frequentemente, assim como a criação de um ambiente propício para tornar a doação de sangue uma experiência agradável, são necessárias para a fidelização dos doadores e manutenção dos estoques em níveis adequados.

3. Para detectar o nível de hemoglobina em candidatos à doação de sangue o HemoCue 201 é preferível ao HemataSTAT II. Além dos fatores de risco bem conhecidos para anemia e depleção da ferritina em doadores de sangue, há outros, mais incomuns, como sangramento do trato gastrointestinal, que merecem ser 
investigados. Algoritmos para orientação e encaminhamento de doadores recusados devem ser uma prioridade dos hemocentros.

4. Os critérios de seleção de doadores de duplos concentrados de hemácias necessitam ser mais restritos para evitar a anemia e depleção dos estoques de ferro nestes.

5. A triagem clínica de doadores de sangue deve ser objeto de avaliação sistemática. 0 risco e o benefício de cada critério de triagem devem ser medidos e balanceados de acordo com as diferenças regionais de cada hemocentro. Métodos mais sensíveis de triagem clínica necessitam ser testados e implantados.

6. O voto de auto exclusão tem pouco impacto na segurança transfusional. Entretanto, tendo em vista que a maioria dos hemocentros realiza a triagem clínica face-a-face, é um instrumento útil para manter a confidencialidade de doadores expostos à situação de risco.

7. Medidas educacionais são importantes para aprimorar a triagem clínica, mas para serem funcionais, necessitam de uma comunicação efetiva entre hemocentro e doador. Diferentes abordagens para aprimorar a comunicação entre hemocentros e doadores devem ter a eficácia testada e medida. 
8. O capital social estrutural e cognitivo dos doadores de sangue estão associados ao altruísmo, e resposta ao apelo direto. O capital social cognitivo também está associado ao interesse próprio. Campanhas de recrutamento considerando estes aspectos podem ajudar os hemocentros a captar mais doadores.

9 Estudos analisando a prevalência, incidência e risco residual das doenças transmissíveis por transfusão são necessários e devem ser sistematicamente realizados para gerar ações visando aumentar a segurança transfusional.

10. O conhecimento dos fatores de risco para a infecção pelo HIV, hepatites virais, Doenças de Chagas e sífilis colabora com a melhoria dos processos da triagem, notificação e aconselhamento de doadores. Entretanto, meios mais sensíveis, como o ACASI, devem ser utilizados para permitir que os doadores possam revelar os riscos a que foram expostos.

11. Em relação à transmissão de HIV/aids e sífilis em doadores de sangue, homem que mantem/manteve relação sexual com outro homem nos últimos 12 meses foi o principal fator de risco identificado.

12. Os testes sorológicos para sífilis têm um papel na prevenção da sífilis transfusional. 
13. O processo de notificação e a simples presença do HCV influenciam negativamente na QVRS dos doadores de sangue.

14. A incidência de miocardiopatia chagásica em doadores de sangue com a forma indeterminada da Doença de Chagas é moderada (1,85 por 100 pessoas-ano). Sexo masculino, história prévia de ECG alterado e presença de B3 ao exame físico indicam maior risco de miocardiopatia e podem ser úteis para decidir quais portadores do $T$. cruzi são potencialmente elegíveis para tratamento.

15. O hemocentro reúne condições adequadas para a realização de estudos observacionais e de intervenção em várias áreas da medicina. Com certa parcimônia, os achados destes estudos podem refletir as condições de saúde de uma determinada população e trazem benefícios para a saúde pública, para a comunidade e para o próprio doador. 


\section{REFERÊNCIAS BIBLIOGRÁFICAS}

1. Brasil. Caderno de informação: sangue e hemodericados. Brasília: Ministério da Saúde; 2014. p. 158.

2. Ammann AJ, Cowan MJ, Wara DW, Weintrub P, Dritz S, Goldman H, et al. Acquired immunodeficiency in an infant: possible transmission by means of blood products. Lancet. 1983;1:956-8.

3. Motta IJ, Spencer BR, Cordeiro da Silva SG, Arruda MB, Dobbin JA, Gonzaga YB, et al. Evidence for Transmission of Zika Virus by Platelet Transfusion. N Engl J Med. 2016;375:1101-3.

4. Brasil. Portaria $\mathrm{n}^{0} 158$ do MS de 4 de fevereiro de 2016. Brasília: DOU de 05/02/2016; 05 de fevereiro de 2016. p. 37.

5. WHO. Global blood safety and avaiability. Facts and figures from the 2007 Blood Safety Survey. Geneve: World Health Organization; 2007.

6. Oliveira CD, de Almeida-Neto C, Liu EJ, Sabino EC, Leao SC, Loureiro P, et al. Temporal distribution of blood donations in three Brazilian blood centers and its repercussion on the blood supply. Rev Bras Hematol Hemoter. 2013;35:246-51.

7. Loureiro P, de Almeida-Neto C, Proietti AB, Capuani L, Goncalez TT, de Oliveira $C D$, et al. Contribution of the Retrovirus Epidemiology Donor Study (REDS) to research on blood transfusion safety in Brazil. Rev Bras Hematol Hemoter. 2014;36:152-8.

8. de Almeida Neto C, Mendrone A, Jr., Custer B, Liu J, Carneiro-Proietti AB, Leao SA, et al. Interdonation intervals and patterns of return among blood donors in Brazil. Transfusion. 2012;52:722-8. 
9. Schreiber GB, Sharma UK, Wright DJ, Glynn SA, Ownby HE, Tu Y, et al. First year donation patterns predict long-term commitment for first-time donors. Vox Sang. 2005;88:114-21.

10. Notari EPt, Zou S, Fang CT, Eder AF, Benjamin RJ, Dodd RY. Age-related donor return patterns among first-time blood donors in the United States. Transfusion. 2009;49:2229-36.

11. Misje AH, Bosnes V, Heier HE. Gender differences in presentation rates, deferrals and return behaviour among Norwegian blood donors. Vox Sang. 2010;98:e241-8.

12. Guo N, Wang J, Ness P, Yao F, Dong X, Bi X, et al. Analysis of Chinese donors' return behavior. Transfusion. 2011;51:523-30.

13. Custer B, Chinn A, Hirschler NV, Busch MP, Murphy EL. The consequences of temporary deferral on future whole blood donation. Transfusion. 2007;47:1514-23.

14. Mendrone A, Jr., Sabino EC, Sampaio L, Neto CA, Schreiber GB, Chamone Dde A, et al. Anemia screening in potential female blood donors: comparison of two different quantitative methods. Transfusion. 2009;49:662-8.

15. Dauar ET, Patavino GM, Mendrone Junior A, Gualandro SF, Sabino EC, de Almeida-Neto C. Risk factors for deferral due to low hematocrit and iron depletion among prospective blood donors in a Brazilian center. Rev Bras Hematol Hemoter. 2015;37:306-15.

16. Cable RG, Glynn SA, Kiss JE, Mast AE, Steele WR, Murphy EL, et al. Iron deficiency in blood donors: the REDS-II Donor Iron Status Evaluation (RISE) study. Transfusion. 2012;52:702-11. 
17. Mendrone A, Jr., Arrais CA, Almeida Neto C, Gualandro Sde F, Dorlhiac-Llacer

PE, Chamone Dde A, et al. Impact of allogeneic 2-RBC apheresis on iron stores of Brazilian blood donors. Transfus Apher Sci. 2009;41:13-7.

18. Brasil. Resolução da Diretoria Colegiada no 153 de 14 de junho de 2004. Brasília: Agência Nacional de Vigilância Sanitária. Ministério da Saúde; 2004.

19. Brasil. Portaria MS no 1.353. de 13 de junho de 2011. Agência Nacional de Vigilância Sanitária: Diário Oficial da União; 14 June 2011.

20. Patavino GM, de Almeida-Neto C, Liu J, Wright DJ, Mendrone-Junior A, Ferreira MI, et al. Number of recent sexual partners among blood donors in Brazil: associations with donor demographics, donation characteristics, and infectious disease markers. Transfusion. 2012;52:151-9.

21. de Almeida-Neto C, Liu J, Wright DJ, Mendrone-Junior A, Takecian PL, Sun Y, et al. Demographic characteristics and prevalence of serologic markers among blood donors who use confidential unit exclusion (CUE) in Sao Paulo, Brazil: implications for modification of CUE policies in Brazil. Transfusion. 2011;51:191-7.

22. Goncalez TT, Sabino EC, Salles NA, de Almeida-Neto C, Mendrone-Jr A, DorlhiacLaccer $\mathrm{PE}$, et al. The impact of simple donor education on donor behavioral deferral and infectious disease rates in Sao Paulo, Brazil. Transfusion. 2010;50:909-17.

23. Goncalez TT, Di Lorenzo Oliveira C, Carneiro-Proietti AB, Moreno EC, Miranda C, Larsen $\mathrm{N}$, et al. Motivation and social capital among prospective blood donors in three large blood centers in Brazil. Transfusion. 2013;53:1291-301. 
24. Oliveira CD, Goncalez T, Wright D, Rocha PC, Miranda C, Capuani L, et al. Relationship between social capital and test seeking among blood donors in Brazil. Vox Sang. 2013;104:100-9.

25. Wendel S, Fachini RM, Levi JE, Ghaname JN, Mendonca MC, de Almeida Neto C, et al. A single window-period donation detected by human immunodeficiency virus p24 antigen after 5 years of routine screening in a group of Brazilian blood banks. Vox Sang. 2002;83:309-12.

26. Sabino EC, Salles N, Saez-Alquezar A, Ribeiro-dos-Santos G, Chamone DF, Busch MP. Estimated risk of transfusion-transmitted HIV infection in Sao Paulo, Brazil. Transfusion. 1999;39:1152-3.

27. Sabino EC, Salles NA, de Almeida-Neto C, Barreto AM, Basques F, Barros EA, et al. Performance of parallel screening of Brazilian blood donors with two human immunodeficiency virus immunoassays: implications for sequential immunoassay testing algorithms in other countries. Transfusion. 2011;51:175-83.

28. Sabino EC, Goncalez TT, Carneiro-Proietti AB, Sarr M, Ferreira JE, Sampaio DA, et al. Human immunodeficiency virus prevalence, incidence, and residual risk of transmission by transfusions at Retrovirus Epidemiology Donor Study-II blood centers in Brazil. Transfusion. 2012;52:870-9.

29. Salles NA, Levi JE, Barreto CC, Sampaio LP, Romano CM, Sabino EC, et al. Human immunodeficiency virus transfusion transmission despite nucleic acid testing. Transfusion. 2013;53:2593-5. 10.1111/trf.12316

30. de Almeida Neto C, McFarland W, Murphy EL, Chen S, Nogueira FA, Mendrone A, Jr., et al. Risk factors for human immunodeficiency virus infection among blood 
donors in Sao Paulo, Brazil, and their relevance to current donor deferral criteria. Transfusion. 2007;47:608-14.

31. de Almeida-Neto C, Goncalez TT, Birch RJ, de Carvalho SM, Capuani L, Leao SC, et al. Risk factors for human immunodeficiency virus infection among Brazilian blood donors: a multicentre case-control study using audio computer-assisted structured interviews. Vox Sang. 2013.

32. Blatyta PF, Custer B, Goncalez TT, Birch R, Lopes ME, Lopes Ferreira MI, et al. Undisclosed human immunodeficiency virus risk factors identified through a computerbased questionnaire program among blood donors in Brazil. Transfusion. 2013.

33. Katz LM, Cumming PD, Wallace EL, Abrams PS. Audiovisual touch-screen computer-assisted self-interviewing for donor health histories: results from two years experience with the system. Transfusion. 2005;45:171-80.

34. Katz LM, Cumming PD, Wallace EL. Computer-based blood donor screening: a status report. Transfus Med Rev. 2007;21:13-25.

35. Locke SE, Kowaloff HB, Hoff RG, Safran C, Popovsky MA, Cotton DJ, et al. Computer-based interview for screening blood donors for risk of HIV transmission. JAMA. 1992;268:1301-5.

36. Miranda C, Moreno E, Bruhn R, Larsen NM, Wright DJ, Oliveira CD, et al. Knowledge of HIV testing and attitudes towards blood donation at three blood centres in Brazil. Vox Sang. 2013;106:344-53.

37. Andrade AF, Oliveira-Silva M, Silva SG, Motta IJ, Bonvicino CR. Seroprevalence of hepatitis B and C virus markers among blood donors in Rio de Janeiro, Brazil, 19982005. Mem Inst Oswaldo Cruz. 2006;101:673-6. 
38. Braga WS, Brasil LM, de Souza RA, Castilho Mda C, da Fonseca JC. [The occurrence of hepatitis B and delta virus infection within seven Amerindian ethnic groups in the Brazilian western Amazon]. Rev Soc Bras Med Trop. 2001;34:349-55.

39. Focaccia R, da Conceicao OJ, Sette H, Jr., Sabino E, Bassit L, Nitrini DR, et al. Estimated Prevalence of Viral Hepatitis in the General Population of the Municipality of Sao Paulo, Measured by a Serologic Survey of a Stratified, Randomized and ResidenceBased Population. Braz J Infect Dis. 1998;2:269-84.

40. Zarife MA, Silva LK, Silva MB, Lopes GB, Barreto ML, Teixeira Mda G, et al. Prevalence of hepatitis C virus infection in north-eastern Brazil: a population-based study. Trans R Soc Trop Med Hyg. 2006;100:663-8.

41. de Almeida-Neto C, Sabino EC, Liu J, Blatyta PF, Mendrone-Junior A, Salles NA, et al. Prevalence of serologic markers for hepatitis B and C viruses in Brazilian blood donors and incidence and residual risk of transfusion transmission of hepatitis $C$ virus. Transfusion. 2013;53:827-34.

42. Alvarez M, Oyonarte S, Rodriguez PM, Hernandez JM. Estimated risk of transfusion-transmitted viral infections in Spain. Transfusion. 2002;42:994-8.

43. Zou S, Stramer SL, Notari EP, Kuhns MC, Krysztof D, Musavi F, et al. Current incidence and residual risk of hepatitis B infection among blood donors in the United States. Transfusion. 2009;49:1609-20.

44. Lampe E, Espirito-Santo MP, Martins RM, Bello G. Epidemic history of Hepatitis C virus in Brazil. Infect Genet Evol. 2010;10:886-95. 
45. Vigani AG, Pavan MH, Tozzo R, Goncales ES, Feltrin A, Fais VC, et al. Comparative study of patients with chronic hepatitis $C$ virus infection due to genotypes 1 and 3 referred for treatment in southeast Brazil. BMC Infect Dis. 2008;8:164.

46. Brasil. Portaria $n^{0} 1.376$ de 19 de novembro de 1993. Brasília: DO 229; 2 de dezembro de 1993.

47. Almeida Neto C, Strauss E, Sabino EC, Sucupira MC, Chamone DA. Significance of isolated hepatitis B core antibody in blood donors from Sao Paulo. Rev Inst Med Trop Sao Paulo. 2001;43:203-8.

48. Torezan-Filho MA, Alves VA, Neto CA, Fernandes HS, Strauss E. Clinical significance of elevated alanine aminotransferase in blood donors: a follow-up study. Liver Int. 2004;24:575-81.

49. Nishiya AS, de Almeida-Neto C, Ferreira SC, Alencar CS, Di-Lorenzo-Oliveira C, Levi JE, et al. HCV genotypes, characterization of mutations conferring drug resistance to protease inhibitors, and risk factors among blood donors in Sao Paulo, Brazil. PLoS One. 2014;9:e86413.

50. Hoffmann L, Ramos JA, Souza EV, Araujo Ramos AL, Villela-Nogueira CA, Urmenyi TP, et al. Dynamics of resistance mutations to NS3 protease inhibitors in a cohort of Brazilian patients chronically infected with hepatitis C virus (genotype 1 ) treated with pegylated interferon and ribavirin: a prospective longitudinal study. Virol J. 2013;10:57.

51. Peres-da-Silva A, de Almeida AJ, Lampe E. Mutations in hepatitis C virus NS3 protease domain associated with resistance to specific protease inhibitors in antiviral therapy naive patients. Arch Virol. 2010;155:807-11. 
52. Zeminian LB, Padovani JL, Corvino SM, Silva GF, Pardini MI, Grotto RM. Variability and resistance mutations in the hepatitis C virus NS3 protease in patients not treated with protease inhibitors. Mem Inst Oswaldo Cruz. 2013;108:13-7.

53. Nishiya AS, Almeida-Neto C, Romano CM, Alencar CS, Ferreira SC, Di-LorenzoOliveira $C$, et al. Phylogenetic analysis of the emergence of main hepatitis $C$ virus subtypes in Sao Paulo, Brazil. Braz J Infect Dis. 2015;19:473-8.

54. Ong SC, Mak B, Aung MO, Li SC, Lim SG. Health-related quality of life in chronic hepatitis B patients. Hepatology. 2008;47:1108-17.

55. Strauss E, Dias Teixeira MC. Quality of life in hepatitis C. Liver Int. 2006;26:75565.

56. Strauss E, Porto-Ferreira FA, de Almeida-Neto C, Teixeira MC. Altered quality of life in the early stages of chronic hepatitis $C$ is due to the virus itself. Clin Res Hepatol Gastroenterol. 2014;38:40-5.

57. Ferreira FA, de Almeida-Neto C, Teixeira MC, Strauss E. Health-related quality of life among blood donors with hepatitis B and hepatitis C: longitudinal study before and after diagnosis. Rev Bras Hematol Hemoter. 2015;37:381-7.

58. WHO. Global Prevalence and Incidence of Selected Curable Sexually Transmitted Infections. World Health Organization; 1999 [updated 1999; cited 2007 11/27/2007]; Available from: http://www.who.int/docstore/hiv/GRSTI/005.htm.

59. de Almeida Neto C, Murphy EL, McFarland W, Junior AM, Chen S, Chamone DA, et al. Profile of blood donors with serologic tests reactive for the presence of syphilis in Sao Paulo, Brazil. Transfusion. 2009;49:330-6. 
60. Risseeuw-Appel IM, Kothe FC. Transfusion syphilis: a case report. Sex Transm Dis. 1983;10:200-1.

61. Owusu-Ofori AK, Parry CM, Bates I. Transfusion-transmitted syphilis in teaching hospital, Ghana. Emerg Infect Dis. 2011;17:2080-2.

62. Marfin AA, Liu H, Sutton MY, Steiner B, Pillay A, Markowitz LE. Amplification of the DNA polymerase I gene of Treponema pallidum from whole blood of persons with syphilis. Diagn Microbiol Infect Dis. 2001;40:163-6.

63. Dow BC, Franklin IM, Munro H, Gunson R. Syphilis nucleic acid testing: usefulness in syphilis confirmation? Transfusion. 2010;50:737-9.

64. Ferreira SC, de Almeida-Neto C, Nishiya AS, Oliveira CD, Ferreira JE, Alencar CS, et al. Demographic, risk factors and motivations among blood donors with reactive serologic tests for syphilis in Sao Paulo, Brazil. Transfus Med. 2014;24:169-75.

65. Ferreira SC, de Almeida-Neto C, Nishiya AS, Di-Lorenzo-Oliveira C, Ferreira JE, Alencar CS, et al. Prevalence of Treponema pallidum DNA among blood donors with two different serologic tests profiles for syphilis in Sao Paulo, Brazil. Vox Sang. 2014;106:376-8.

66. Salles NA, Sabino EC, Cliquet MG, Eluf-Neto J, Mayer A, Almeida-Neto C, et al. Risk of exposure to Chagas' disease among seroreactive Brazilian blood donors. Transfusion. 1996;36:969-73.

67. Sabino EC, Ribeiro AL, Salemi VM, Di Lorenzo Oliveira C, Antunes AP, Menezes $M M$, et al. Ten-year incidence of Chagas cardiomyopathy among asymptomatic Trypanosoma cruzi-seropositive former blood donors. Circulation. 2013;127:1105-15. 
68. Pozo AE, Perez-Rosales MD, Almeida-Neto C, Remesar MC, Cortes AD, Delgado $\mathrm{RB}$, et al. A comprehensive protocol to evaluate the use of blood and its components in Latin America and the Caribbean. Rev Panam Salud Publica. 2015;37:435-41.

69. Dionisio Tavares Niewiadonski V, Dos Santos Bianchi JV, de Almeida-Neto C, Gaburo N, Jr., Sabino EC. Evaluation of a high throughput method for the detection of mutations associated with thrombosis and hereditary hemochromatosis in Brazilian blood donors. PLoS One. 2015;10:e0125460.

70. De Stefano V, Rossi E. Testing for inherited thrombophilia and consequences for antithrombotic prophylaxis in patients with venous thromboembolism and their relatives. A review of the Guidelines from Scientific Societies and Working Groups. Thromb Haemost. 2013;110:697-705.

71. Silliman CC, Ambruso DR, Boshkov LK. Transfusion-related acute lung injury. Blood. 2005;105:2266-73.

72. Chapman CE, Stainsby D, Jones H, Love E, Massey E, Win N, et al. Ten years of hemovigilance reports of transfusion-related acute lung injury in the United Kingdom and the impact of preferential use of male donor plasma. Transfusion. 2009;49:440-52. 73. Blatyta PF, Custer B, Liu J, Mendrone-Junior A, Wright DJ, Leao SC, et al. The impact of policies to restrict the use of plasma containing products and apheresis platelets from female donors to mitigate transfusion related acute lung injury (TRALI) in Brazil. Transfus Apher Sci. 2013;48:15-20. 
74. WHO. Blood safety and availability. World Health Organization; 2015 [updated 2015; cited $2016 \quad 24 \quad$ March]; Available from: www.who.int/mediacentre/facsheets/fs279/en/.

75. Agarwal N. Response rate of blood donors in the Uttarakhand region of India after notification of reactive test results on their blood samples. Blood Transfus. 2013;12 Suppl 1:s51-3.

76. Porto-Ferreira FA, de Almeida Neto C, Murphy EL, Montebello SC, Nogueira $\mathrm{FAH}$, Silva $\mathrm{E}$, et al. A randomized trial to evaluate the use of text messaging, letter and telephone call reminders to improve return of blood donors with reactive serologic tests. Transfusion. [no prelo]. 